\title{
CHECKLIST OF PYRENEAN ALPINE-STAGE MACROFUNGI
}

\author{
G. Corriol
}

Corriol, G. 2008. Checklist of Pyrenean alpine-stage macrofungi. - Sommerfeltia 31: 29-99. Oslo. ISBN 82-7420-045-4. ISSN 0800-6865.

Macrofungi from the alpine stage of the Pyrenees are poorly known. In this paper we first describe the alpine habitats of this mountain chain, then provide an overview with bibliography for all known taxa, with information on distribution and habitat. In addition to the 214 taxa of macrofungi previously known from the Pyrenees, 83 new taxa are reported from the French side of the Pyrenees. The total number of taxa reported for the alpine stage of the Pyrenees is now 297, of which 19 are Ascomycetideae, 260 Agaricomycetideae, 11 Gasteromycetideae and 7 Aphyllophoromycetideae. The genera richest in species are: Inocybe (53 taxa), Entoloma (41 taxa), Cortinarius (36 taxa), Hygrocybe ss. lato (20 taxa) and Melanoleuca (12 taxa). Of the 297 taxa reported, 103 are true arctic-alpine fungi.

Key-words: Andorra, arctic-alpine communities, chorology, France, Fungi, Inventory, mycocoenology, Spain.

Gilles Corriol, Conservatoire botanique pyrénéen, Conservatoire botanique national de MidiPyrénées. Vallon de Salut. B.P. 315. F-65203 Bagnères-de-Bigorre cedex.France.cbp.gc@laposte. net

\section{INTRODUCTION}

The fungus flora of the alpine stage in the Alps has been the subject of relatively intense study since Jules Favre's observations in 1955. French mycologists such as R. Kühner, D. Lamoure, G. Bruchet, M. Eynard, M. Bon, J.-L. Cheype, Swiss mycologists such as E. Horak and B. Senn-Irlet and Italian mycologists such as P.G. Jamoni and E. Bizio have contributed extensively to the knowledge of taxonomy, ecology and distribution of alpine fungi from the Alps (e.g. Kühner et Lamoure 1970, Bruchet 1970, Eynard 1977, Lamoure 1982, Bon 1985a, 1985b, 1989, 1991, Kühner \& Lamoure 1986, Senn-Irlet 1986, 1988, 1993, Bon et Cheype 1987, Horak 1987a,1987b, 1993, Jamoni 1993, 1995a, 1995b, Cheype 1997, Bizio 1997).

The Pyrenees, a natural frontier between France and Spain, is a high mountain chain with many summits above 3000 meters. Despite relatively low latitudes, typically alpine habitats are present (Dupias 1985: 167). Nevertheless, the study of Pyrenean alpine macrofungi has only recently begun. So far, mainly the Catalan Pyrenees (especially in Spain and Andorra) has attracted interest, by Spanish mycologists from Catalonia such as J. Ballarà, L. Escànez, X. Llimona, J. Llistosella, J. Vila, and F. Esteve-Raventós and R. Galán from Madrid (Ballarà 1997, Escánez 1999, Esteve-Raventós 
\&Vila 1997, 1998, Galán \& al. 1997, Vila \& Llimona 1998, Vila \& Esteve-Raventós 1998, Vila et al. 1997, 1998, 2000).

Very few French mycologists have studied Pyrenean alpine macrofungi. Noticeable exceptions include Bon who studied J. Ballarà's alpine collections from the Catalan Pyrenees (Bon \& Ballarà 1995, 1996, 1997), Lassueur (1988) who recorded one Scutellinia species and Magni (1989) who recorded three Bovista species from the French side of the Central Pyrenees. Some unpublished data by N. de Munnick from Ariège (a French Department located on the eastern-central side of the mountain) could also be mentioned. At present, very few studies have been carried out on the high central massifs of the chain such as the Ordesa National Parc in Spain (Esteve-Raventós et al.1997) and data from French side of the Pyrenees remain very scarce. These facts can probably be partly explained by some characteristics of this mountain chain such as (1) the topography of the Pyrenees, with very steep valleys and slopes is not favourable to a large extension of alpine snow-bed communities, which are so rich in alpine macromycetes; and (2) on account of the low latitude, high altitudes must be reached to attain the alpine stage and the differential height to climb on foot is generally more than one thousand meters except for very few sites.

Our studies of alpine macrofungi of the central part of the French Pyrenees started in 2002 (Corriol \& Largier 2004, Corriol 2006). Thereafter, an inventory project of the fungi of the MidiPyrénées region (France) has been initiated with financial support from the European Union and the regional authorities (Corriol et al. 2004). A mycological database has been created, populated with data collected between 2002 and 2004 (bibliographic data, own field data and unpublished data from regional mycologists and other correspondents).

In this paper we report all published taxa of macrofungi (sensu Arnolds 1981) from the Pyrenean Alpine stage, information from our own collections made between 2002 and 2006, and some collections made by correspondents. Attempts are made to associate each collection with type of alpine habitat.

\section{THE STUDY AREA}

\section{The Pyrenees}

The Pyrenees are a $440 \mathrm{~km}$ long west-east oriented mountain chain located between $42^{\circ}$ and $43^{\circ}$ north latitude (see Fig. 1). It spreads from Atlantic ocean to Mediterranean sea, with a $150 \mathrm{~km}$ maximum width and separates the Iberian peninsula from France. French side at the north is narrow and strongly sloping. Spanish side at the south is twice as wide and has a more gradual slope. At the eastern part of the axial chain, a little country, Andorra is encircled between France and spain. The axial zone is formed by primary sediments mainly consisting of siliceous rocks but also locally by hard limestone and dolomite. From one side to the other, a secondary cover made of calcareous and marleous sediments envelops the axial zone. Tertiary sediments only play an important role in the pre-Pyrenees of the spanish side. Quaternary glaciations had a big impact on geomorphology, building deep valleys, large cirques, numerous lakes in high altitude depressions, etc. The higher summits (many of them beyond $3000 \mathrm{~m}$ ) are found between the Anie's peak $(2504 \mathrm{~m}$ ) at the west, $100 \mathrm{~km}$ from the Atlantic ocean, and the Canigou ( $2785 \mathrm{~m}$ ) at the east, $48 \mathrm{~km}$ far from the Mediterranean sea. The Aneto's peak (3404 m), in central spanish side is the top of the Pyrenees. (Dupias 1985).

The climate is very contrasted between north and south sides, particularly in central part of the chain. At the french side, it is fundamentally oceanic (except at the east of Andorra where it is more 


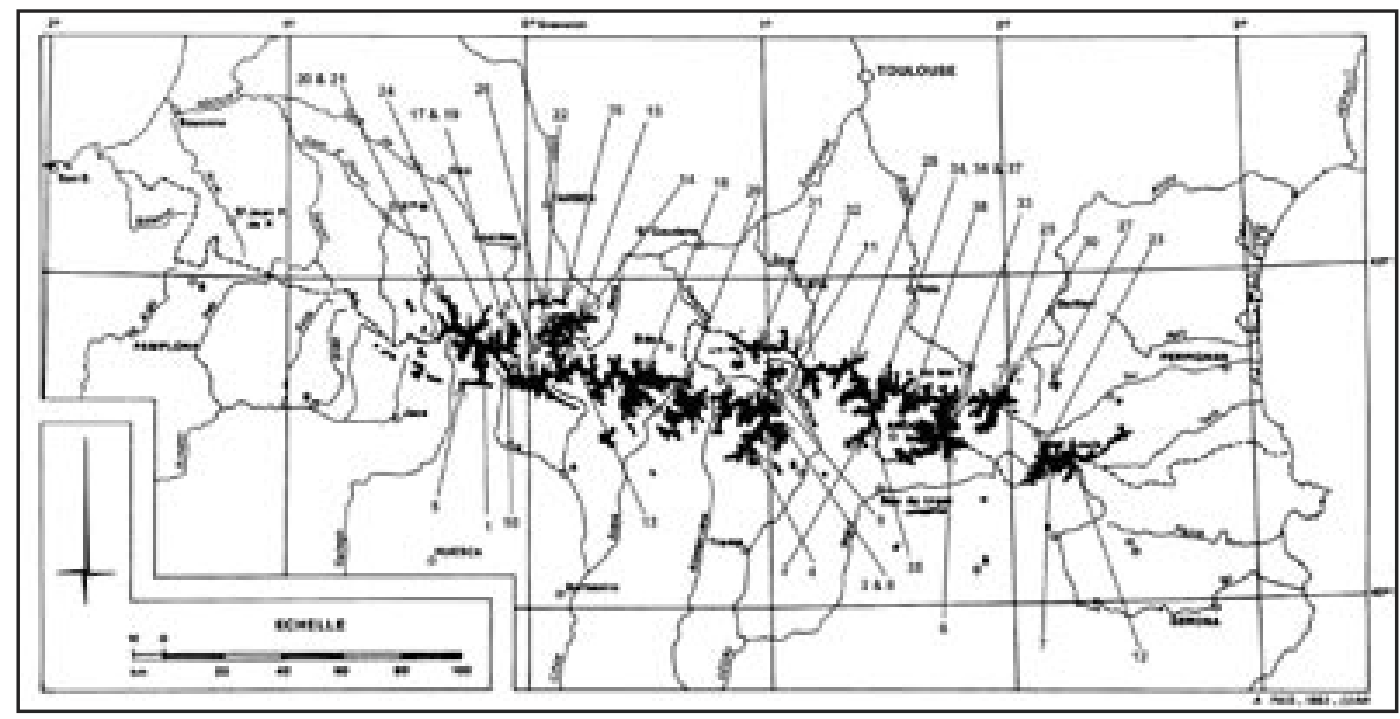

Fig. 1. The alpine sites prospected, on the map of alpine stage of the Pyrenees, according to Païs in Dupias (1985).

continental). High amounts of precipitations are due to north-western cyclones. Annual precipitation mostly amounts to more than $1000 \mathrm{~mm}$ in normal years, while up to $2600 \mathrm{~mm}$ has been recorded in the western part. Some internal deep valleys (e.g. Gavarnie, Aure, Aran) and the Cerdan plateau at the eastern part are more protected and are, hence, more continental. To the south of the frontier crest, one can find more areas with distinctly continental climate except in the occidental end which is very oceanic throughout. The mediterranean influences are important as soon as altitude decreases (Izard in Dupias 1985).

Moreover, the climate is strongly influenced by altitude. The altitudinal zonation of vegetation has four stages: the collinean (or mediterranean in the south side) stage, the mountain stage, the subalpine stage and the alpine stage (a nival stage is very fragmentarily represented on the highest summits).

\section{The alpine stage in the Pyrenees}

The alpine stage as studied here is considered in its strict sense. Its distribution along the chain is shown in Fig. 1. It is defined as comprising all altitudinal stations in which the micro-, meso- or macroclimatic conditions do not permit the growth of phanerophytes (lignose plants taller than 30 $\mathrm{cm}$ ). Some of the ecological characteristics are a short vegetation period (less than a hundred days per year) and an annual average temperature of less than $0^{\circ} \mathrm{C}$. Moreover, the temperature contrasts between day and night during the vegetation period are very strong, particularly due to the strong radiation of the ground related to the low density of the air. Also, solar radiation is intense and rich in ultra-violet rays. Precipitation is high throughout the year, mainly in the form of snow. Annual rainfall probably amounts to more than $1500 \mathrm{~mm}$ per year in average in every alpine locality of the 
Pyrennees and twice as much in some of central and western parts of the chain. Air humidity is subject to sharp and rapid contrasts, between saturation and drought. The periglacial phenomena can be intense in the intermediate seasons (beginning and end of summer) creating physical disturbances in the substrates (gelifraction, cryoturbation).

In the Pyrenees as in most other high mountains of Europe, timbering has been strongly influenced by human activities. High-altitude sites were (and are still) used as summer pastures and the timberline has usually been lowered by clearings and cuttings for human and cattle needs. Over wide areas in the Pyrenees, this impact has been so important that the subalpine stage of whole valleys has been cleared and still only contain grasslands or heathlands, instead of the original mountain pine (Pinus uncinata Mill. ex Mirb.) native forests. Under these circumstances, it is not possible to use the current timberline as a good indicator of the beginning of the alpine stage.

Nevertheless, the alpine stage can be well characterised by typical alpine habitats and vegetation. Analysis of plant communities was therefore used to identify the alpine altitudinal stage. To our experience, the lower stations of alpine habitats in the Pyrenees are to be found above $2200 \mathrm{~m}$. At that altitude, they represent mainly small habitats in microstational conditions (for example small confined snow-beds at north exposure). The surrounding habitats are however still related to the subalpine stage (for example Nardus grasslands of the Nardion strictae communities). They are usually poorer in alpine macrofungi as if the stational conditions were not optimal or as if the climatic stress was not important enough for the plant communities to develop the highly specialised alpine ectomycorrhizic symbiosis. The lower altitudinal limit of the typical continuous alpine stage varies a lot, depending notably on the exposure and position in the chain. In the peripheral massifs of the centre of the French side of the chain, the limit is situated between 2200 and $2300 \mathrm{~m}$ at northerly exposures, though in the internal massifs the limit is higher. In the oriental part, which has more Mediterranean influences, it can go up to $2600 \mathrm{~m}$ on favourably exposed slopes. It is mainly higher than that of the Alps on account of the lower latitude of the Pyrenees.

Study sites

An overview of studied sites is given in Table 1.

\section{MATERIAL, METHODS AND TERMINOLOGY}

\section{Material and methods}

All published taxa of macrofungi (sensu Arnolds 1981), reported from the Pyrenean Alpine stage, including information from our own collections made between 2002 and 2006, and some collections made by correspondents, are reported. Attempts are made to associate each collection with type of alpine habitat.

As a specific alpine Pyrenean fungi bibliography is sparse, we have mainly based our determinations on literature about the alpine zone of the Alps.

Our prospecting was focused on snow-bed communities of Salicetea herbaceae, but contiguous habitats were examined too. The Agaricomycetideae were mainly studied and some Ascomycota were probably overlooked. Some trivial taxa were determined in the field, but most of taxa observed in good state were collected for laboratory examination. Microanatomy of the collections was studied 
both on fresh and dry material, with a microscope equipped with a 100x immersion lens. The best collections were photographed in the field. Only the records which correspond to the alpine stage as defined before are listed in the catalogue of species. Nevertheless, some dubious alpine collections have been included due to the lack of ecological and/or floristical instage given by the authors.

\section{Terminology for habitat types}

We used the terminology of the French prodrome of vegetation (Bardat $\&$ al., 2004) for description of alpine habitats of Pyrenees in which macrofungi were recorded. This vegetation classification accords with the Braun-Blanquet approach to phytosociology (e.g. Braun-Blanquet 1964). A list of phytocoena with brief desciption is given in Table 2 .

\section{RESULTS}

Although a systematic inventory of macrofungi from the alpine stage of the Pyrenees has only been carried out for five years (2002-2006), 297 taxa have already been reported, mainly thanks to Catalan mycologists. Only 19 of these are Ascomycetideae and 7 are Aphyllophoromycetideae. Gasteromycetideae are quite well represented with 11 taxa. The best represented (and best known) group are the Agaricomycetidea with 260 recorded taxa. Arctic-alpine taxa are well represented, with 103 taxa. The remaining list consists in widely distributed taxa, especially grassland fungi and ectomycorhizal fungi with wide range, usually associated with trees at lower altitude. The genera richest in species are: Inocybe (53 taxa, including 30 arctic-alpine), Entoloma (41 taxa including 4 arctic-alpine), Cortinarius (36 taxa, including 27 arctic-alpine), Hygrocybe ss. lato (20 taxa, including 2 arctic-alpine) and Melanoleuca (12 taxa, not including any arctic-alpine taxa).

The richest habitats are represented by the snow-beds (Salicetea herbaceae). Alpine microheathlands (Loiseulerio-Vaccinietea) and grasslands (Festuco-Seslerietea, Caricetea curvulae and Carici-Kobresietea) are also interesting habitats for alpine fungi in the Pyrenees.

\section{DISCUSSION}

On account of the disparity of the data, the known distribution of macrofungal taxa along the mountain chain mainly represents the distribution of the data and not the real distribubution of the taxa. However, we noticed a surprising fact: except the recent report of Russula alpigenes in Néouvielle and Pic-du-Midi de Bigorre massifs, no Russulaceae had been been found in the central Pyrenees alpine stage although several Russula and Lactarius taxa are reported from the eastern part of the chain. We can clearly see on Fig. 1 two distinct sectors of the alpine zone along the chain on either side of the Pallaresa River. These two sectors correspond to the distribution of alpine Pyrenean endemic phanerogams, for example Androsace ciliata DC. for the western part and Cerastium pyrenaicum J. Gay for the eastern part (Dupias 1985: 58, 60). It would be interesting to test the hypothesis that alpine macrofungal coenoses of these two sectors have evolved differently, with for example, an eventual impoverishment of the Russulaceae family in the central part. 


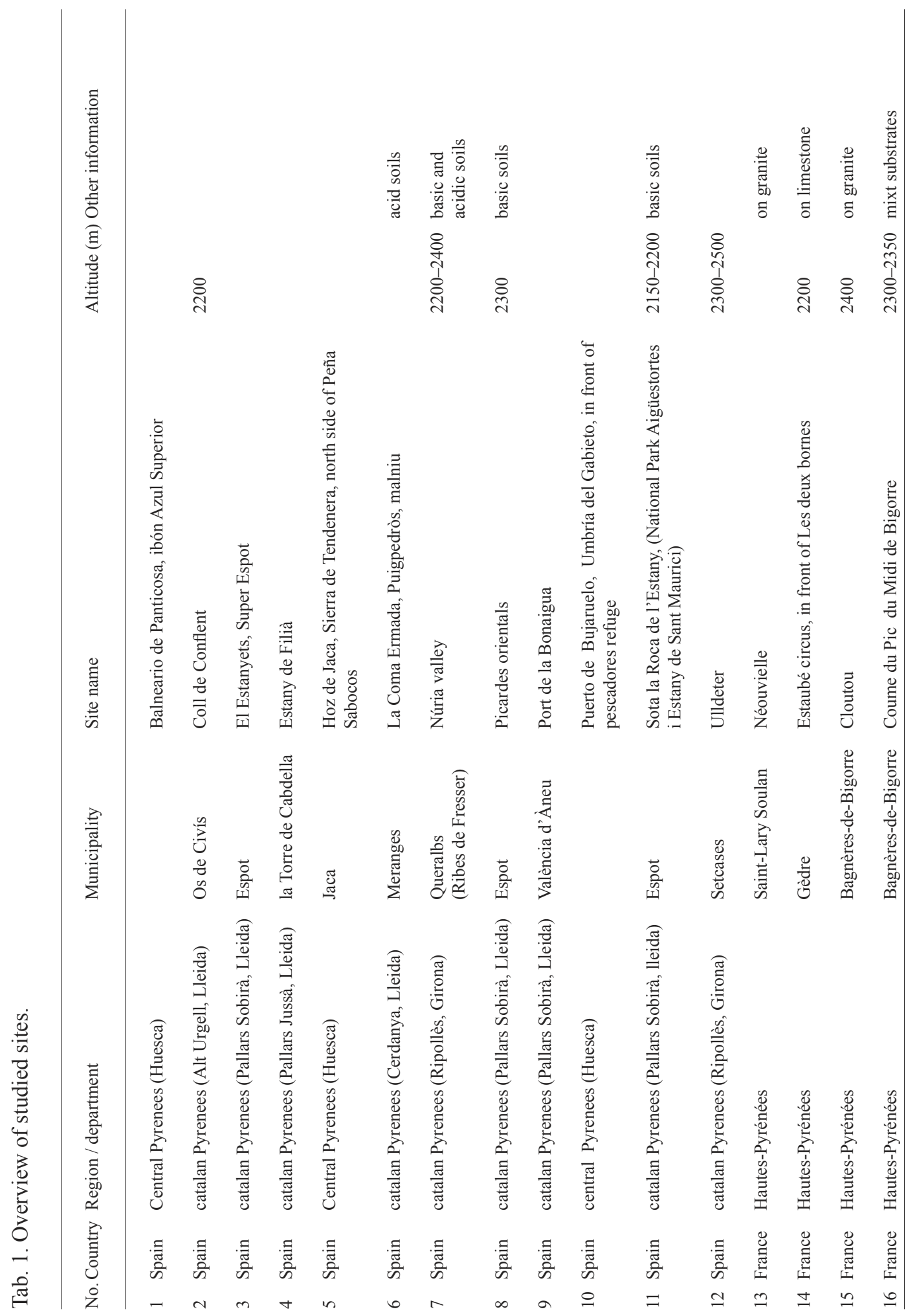




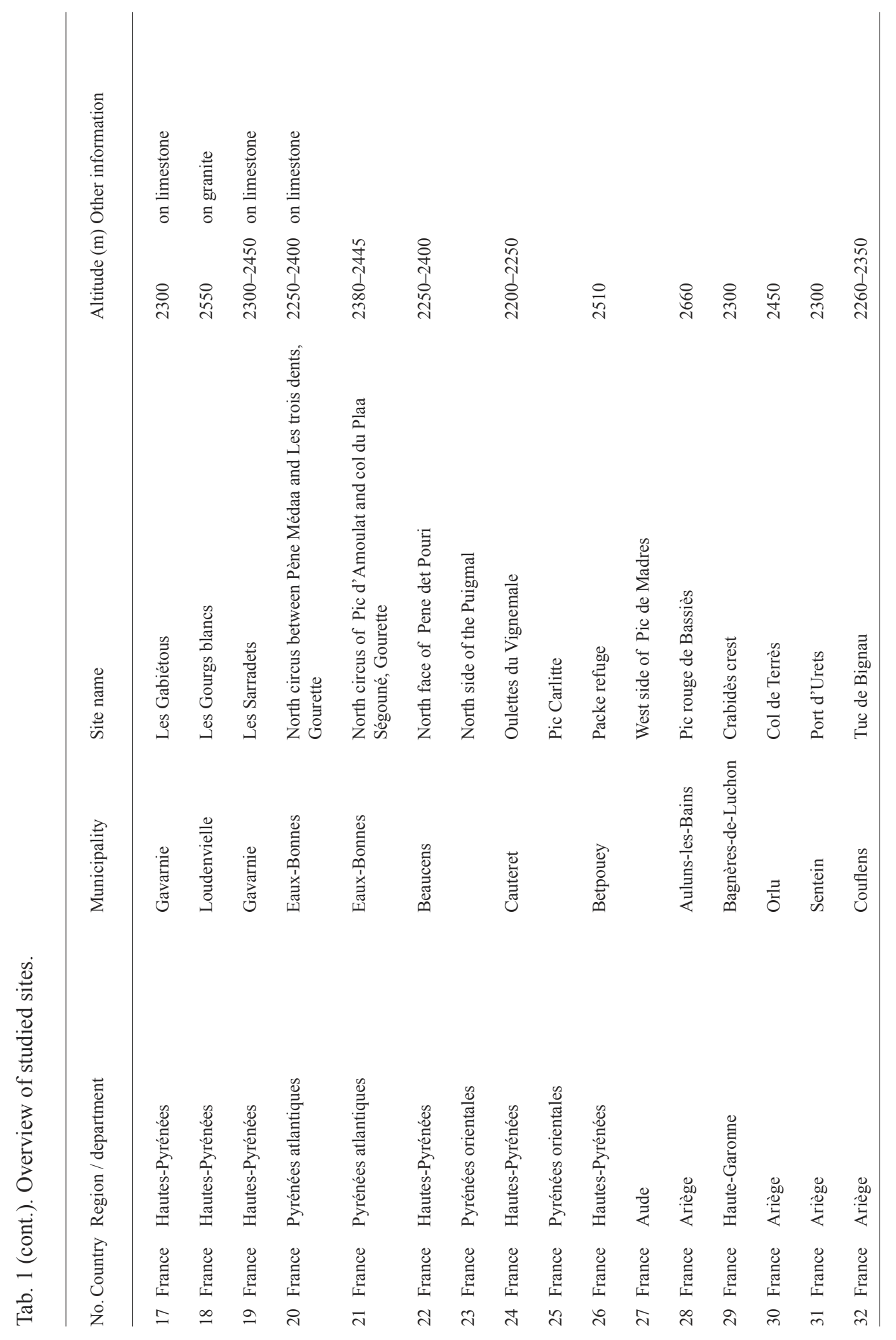




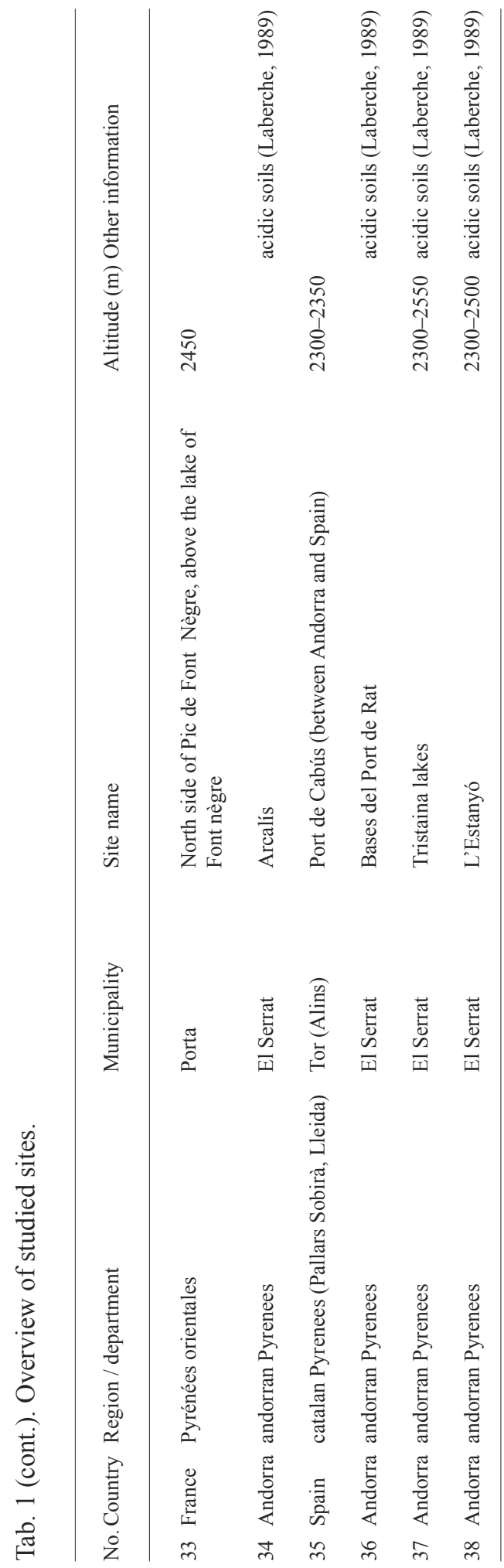




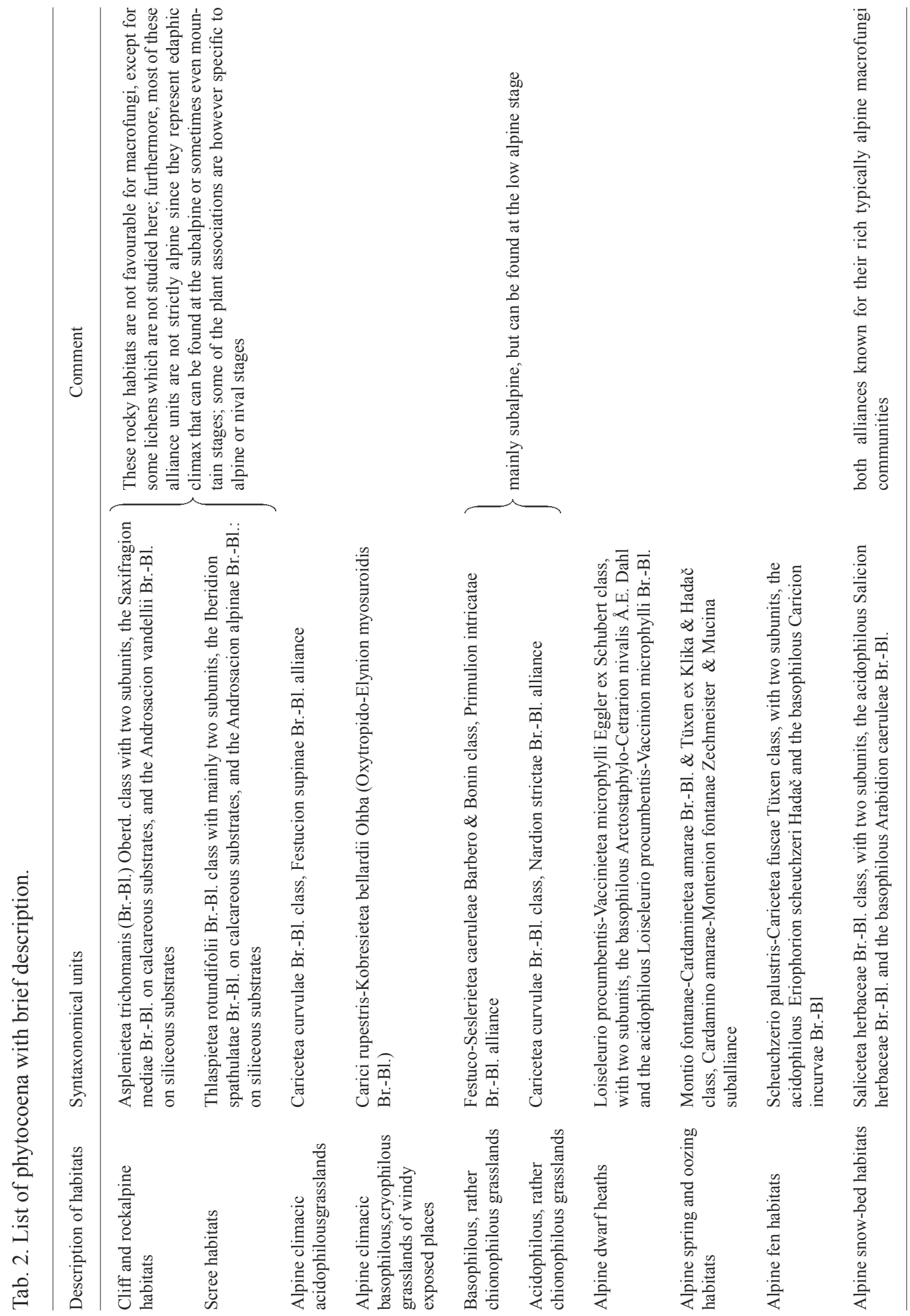


An important factor to explain the distribution of macrofungal species richness on different habitat types is the presence of ectomycorhizal symbiote in plant communities, such as alpine dwarf willows and Dryas octopetala. However, several habitat types as alpine fens should be studied in more details, notably for biotrophic ascomycetes.

The 83 new taxa reported by us demonstrate how fragmentary the knowledge is of this remarkable part of the biodiversity of the higher summits in Pyrenees. However, this inventory forms a good starting point for further research, which should be conducted in the the near future. In comparison, in the Alps, 229 taxa were inventoried by Favre (1955) in the alpine stage of the Swiss national park and 325 taxa by Kühner \& Lamoure (1986) (only Agaricomycetideae were studied) in the Vanoise area of French Alps. In northern Europe, Gulden (2005) quotes 332 different taxa in the Finse area of the Hardangervidda plateau in central south Norway, a boreo-alpine site. Gulden \& Torkelsen (1996), completed by Noordeloos \& Gulden (2004) and Eyssartier \& Delannoy (2006) quote 209 different taxa in the arctic archipelago of Svalbard. The taxonomical distribution of the taxa reported in these studies is reported in Table 3. The distribution of the taxa is globally comparable. Some differences may be explained by the lack of study in some groups, such as Ascomycetideae or Aphyllophoromycetideae. The genus Inocybe seems to be better represented in the Alps and the Pyrenees than in boreo-arctic areas. The genera Mycena and Galerina wich are much well represented in Finse inventories were especially studied by Gulden (Gulden \& Jenssen 1982, Gulden 1980). The genus Galerina was also particularly studied in Svalbard (Gulden \& Vesterholt 1999). However, for Galerina species it seems to us that the Pyrenean alpine stage is less favorable than that of Finse, Svalbard or even the Alps: actually, the favorable habitats such as snow-bed with very long snow-cover, alpine fens or Sphagnum bogs are much rarer in the Pyrenean sites.

Vast amounts of field work is still needed in the Pyrenees, notably in the central part of the chain. More taxonomic work also remains to be done. At present, several collections in our herbarium are still unnamed. The ecology of the fungal species also needs to be studied in more detail since we can see that for many data, the ecological descriptions are still not sufficient. Mycocoenological conclusions are dependent on this preliminary phase.

\section{COMMENTED LIST OF SPECIES}

\section{Ascomycota}

Chlorosplenium cenangium (De Not.) Korf.

Previously published record: Vila et al. (1998).

Collections cited: site 12, 16 Jun 1997, 25 Jun 1997 and 2 Aug 1997.

Notes on habitat: The habitat is described as 'on dead twigs of Rhododendron ferrugineum at 2200-2450 m'. The altitude at which the collection was made leaves it open if the locality was alpine or subalpine. The substrate is a typical subalpine plant. If alpine, the habitat may be Loiseleurio-Vaccinion in which Rhododendron ferrugineum can be found in dwarf isolated forms.

Specimen examined: None.

Colpoma juniperi (P. Karst. ex P. Karst.) Dennis

Previously published record: Vila \& al. (1998).

Collection cited: Site 12, 16 Jul 1997. 
Tab. 3. Taxonomical distribution of macrofungi reported from different alpine and arctic areas.

\begin{tabular}{|c|c|c|c|c|c|}
\hline Reference & This work & Favre (1955) & $\begin{array}{l}\text { Kühner \& } \\
\text { Lamoure } \\
(1986)\end{array}$ & $\begin{array}{l}\text { Gulden \& } \\
\text { Torkelsen } \\
\text { (1996), } \\
\text { Noordeloos } \\
\text { \& Gulden } \\
\text { (2004), } \\
\text { Eyssartier } \\
\text { \& Delannoy } \\
\text { (2006) }\end{array}$ & Gulden (2005) \\
\hline Place & Pyrenees & $\begin{array}{l}\text { Swiss } \\
\text { national } \\
\text { park (Alps) }\end{array}$ & $\begin{array}{l}\text { Vanoise } \\
\text { (French Alps) }\end{array}$ & Svalbard & $\begin{array}{r}\text { Finse area } \\
\text { (Norway) }\end{array}$ \\
\hline Total number of taxa & 297 & 229 & 325 & 209 & 332 \\
\hline Ascomycetideae & 19 & 12 & not studied & 17 & 42 \\
\hline Aphyllophoromycetideae & 7 & 3 & not studied & 20 & 49 \\
\hline Gasteromycetideae & 11 & 12 & not studied & 10 & 6 \\
\hline Agaricomycetidea & 260 & 202 & 325 & 145 & 235 \\
\hline Inocybe & 53 & 56 & 60 & 14 & 18 \\
\hline Entoloma & 41 & 21 & 42 & 13 & 24 \\
\hline Cortinarius & 36 & 28 & 34 & 18 & 26 \\
\hline Hygrocybe & 20 & 13 & 28 & 2 & 10 \\
\hline Melanoleuca & 12 & 4 & 6 & 1 & 1 \\
\hline Russula & 8 & 6 & 8 & 7 & 5 \\
\hline Hebeloma & 7 & 4 & 12 & 5 & 6 \\
\hline Clitocybe & 7 & 6 & 17 & 8 & 8 \\
\hline Bovista & 7 & 4 & not studied & 1 & 1 \\
\hline Arrhenia & 6 & 6 & 13 & 10 & 10 \\
\hline Lepista & 6 & 2 & 3 & 1 & 1 \\
\hline Mycena & 5 & 3 & 8 & 8 & 23 \\
\hline Scutellinia & 5 & 0 & not studied & 2 & 7 \\
\hline Helvella & 5 & 7 & not studied & 1 & 3 \\
\hline Galerina & 4 & 5 & 12 & 15 & 20 \\
\hline
\end{tabular}

Notes on habitat: The habitat is described as 'on dead twigs of Juniperus nana at $2400 \mathrm{~m}$ '. According to the altitude and probable acidic substrate, it may be Loiseleurio-Vaccinion. However, more ecological data are needed (exposure, associated vegetation...) because dwarf Juniperus communis forms are widely distributed at subalpine well exposed slopes which can reach high altitudes at the oriental part of the chain.

Specimen examined: None. 


\section{Geopora arenicola (Lév.) Kers}

Previously published record: Ballarà (1997).

Collection cited: Site 3, 18 Aug 1996.

Notes on habitat: The habitat is described as 'near Dryas octopetala, 2300-2350 m'. It may be Primulion intricatae, Oxytropido-Elynion, or Arctostaphylo-Cetrarion. More ecological and floristical data are necessary.

Specimen examined: None.

\section{Geopora nicaeensis (Boud.) M. Torre}

Previously published record: Vila \& al. (1998).

Collection cited: Site 7, 27 Aug 1997.

Notes on habitat: The habitat is described as 'between Dryas octopetala at 2220 m'. According to its altitude, this collection may come from superior subalpine stage calcareous grasslands of Primulion intricatae. However, we keep the data in the checklist since this species is known to grow in true alpine habitats at least in the Swiss Alps (Favre, 1955 as Sepultaria foliacea alpine form) and Norway (Schumacher, in Schumacher \& Jenssen 1992) and could very likely be found in alpine stage in the Pyrenees too.

Specimen examined: None.

Helvella acetabulum (L.: Fr.) Quél.

Previously published record: Ballarà (1997).

Collection cited: Site 35, 31 Aug 1996.

Notes on habitat: The habitat is described as 'among Dryas octopetala at 2300 m'. It may be Primulion intricatae, Oxytropido-Elynion or Arctostaphylo-Cetrarion. More ecological and floristical data are necessary.

Specimen examined: None.

\section{Helvella arcto-alpina Harmaja}

Previously published record: Esteve-Raventós \& al. (1997).

Collection cited: Site 10, 17 Jul 1996.

Notes on habitat: The habitat is described as 'on limestone, between Salix pyrenaica at 2100 $\mathrm{m}$ '. According to the relatively low altitude, this is very likely a subalpine collection, may be from a Primulion intricatae grassland. We quote this data since $H$. arcto-alpina is a typical arctic-alpine species (Favre 1955, under the name of Acetabula barlae Boud.; Schumacher \& Jenssen 1992) and could then be found in true alpine habitat in the Pyrenees too.

Specimen examined: None.

Helvella corium (O. Weberb.) Massee

Previously published record: Ballarà (1997).

Collection cited: Site 8, 18 Aug 1996.

Notes on habitat: The habitat is described as 'between mosses, not far from Salix reticulata and Arctostaphylos uva-ursi, 2300-2400 m'. It probably is Arabidion caeruleae.

Specimens examined: GC 02083006, site 21, 30 Aug 2002, Arabidion caeruleae, leg. \& det. G. Corriol. - Not preserved, site 17, 10 Sep 2003, Arabidion caeruleae, leg. \& det. G. Corriol. - GC 04091907, site 22, 19 Sep 2004, Salicion herbaceae, leg. \& det. G. Corriol. - Not preserved, site 22, 9 Sep 2006, Salicion herbaceae, leg. \& det. G. Corriol. 
Helvella dovrensis T. Schumach. $=$ H. alpestris Boud. ss. Favre (1955), Häffner (1987).

Previously published record: None.

Specimens examined: GC 04082501, site 24, 25 Aug 2004, Arabidion caeruleae, leg. G. Corriol, T. Le Moal, P. Burr \& N. Lavaupot, det. G. Corriol. - GC 04082701, site 19, 27 Aug 2004, Arabidion caeruleae, leg. G. Corriol, P. Burr \& P. Hériveau, det. G. Corriol. - Not preserved, site 19, 10 Sep 2004, Arabidion caeruleae, leg. \& det. G. Corriol and 14 Sep 2005 , Arabidion caeruleae, leg. G. Corriol \& N. Lavaupot, det. G. Corriol.

Helvella solitaria (P. Karst.) P. Karst. ss. Harmaja (= H. queletii Bres.)

Previously published record: Ballarà (1997).

Collection cited: Site 3, 18 Aug 1996.

Notes on habitat: The habitat is described as 'among Dryas octopetala, 2300-2350 m'. It may be Primulion intricatae, Oxytropido-Elynion or Arctostaphylo-Cetrarion. More ecological and floristical data are necessary.

Previously published record: Vila \& al. (2001).

Collection cited: Site 7, 10 Aug 1999.

Notes on habitat: The habitat is described as 'between Dryas octopetala and Salix retusa at 2300 m'. It may be Arabidion caeruleae or Oxytropido-Elynion. More ecological and floristical data are necessary.

Specimen examined: None.

Hyalopeziza nectrioidea (Rehm) Raschle

Previously published record: Vila \& al. (1998).

Collection cited: Site 12, 25 Jun 1997 and 16 Jul 1997.

Notes on habitat: The habitat is described as 'on dead twigs of Rhododendron ferrugineum at 2200-2375 m'. See notes under Chlorosplenium cenangium.

Specimen examined: None.

Hymenoscyphus conscriptus (P. Karst.) Korf

Previously published record: None

Specimen: NdM 97100207/2048-9 (not examined by us), site 32, 2 Oct 1997, on Salix reticulata trunk and roots (Arabidion caeruleae), leg. \& det. N. de Munnik.

Lachnum latebricola (Rehm) R. Galán \& Raitv.

Previously published record: Vila \& al. (1998).

Collection cited: Site 12, 25 Jun 1997.

Notes on habitat: The habitat is described as 'on dead twigs of Rhododendron ferrugineum at 2375 m'. See notes under Chlorosplenium cenangium.

Previously published record: Galàn \& al. (1997).

Collection cited: Site 36, 10 Jul 1996. - Site 37, 15 Jul 1993 and 15 Jul 1995.

Notes on habitat: The habitat is described as 'on dead, melting-snow-covered branches of Rhododendron ferrugineum at 2405 m' and as 'on dead branches of Rhododendron ferrugineum'. See notes under Chlorosplenium cenangium.

Specimen examined: None.

Octospora borealis (Eckblad) Caillet \& Moyne

Previously published record: Vila \& al. (1998). 
Collection cited: Site 7, 12 Aug 1997.

Notes on habitat: The habitat is described as 'between mosses and Dryas octopetala at 2220 $m$ '. According to its altitude, this collection may have been done at superior subalpine stage calcareous grasslands of Primulion intricatae. We quote it however since the authors have done many alpine records in this place at this altitude with Salix retusa.

Specimen examined: None.

Peziza badia Pers. : Fr.

Previously published record: Vila \& al. (2001).

Collection cited: Site 12, 7 Aug 1999.

Notes on habitat: The habitat is described as 'between Salix herbacea at 2350 m'. It certainly is a snow bed of the Salicetea herbaceae class, but without more floristical or stational information, we cannot choose between the Salicion herbaceae or Arabidion caeruleae alliances.

Specimen examined: None.

Scutellinia minor (Velen.) Svrček

Previously published record: None. G. Corriol.

Specimen examined: GC 03090204, site 24, 2 Sep 2003, Salicion herbaceae, leg. G. Corriol and T. Le Moal, det.

Scutellinia scutellata (L. : Fr.) Lambotte

Previously published record: Rocabruna \& al. (1994).

Collection cited: Site 37, 17 Jul 1993.

Notes on habitat: Coprophilous (on cow dung, at $2260 \mathrm{~m}$ ).

Specimen examined: None.

Scutellinia cf. subhirtella Svrček

Previously published record: None.

Taxonomic notes: We hesitate to name this collection from this very extreme alpine snow bed as S. subhirtella is given by Schumacker (1990) as a boreo-temperate species. The macro- and microscopic features match quite well with this author's description, but the warts on the spores seem to be partially coalescent.

Specimen examined: GC 06083108, site 13, Montagne de Cap de Long, altitude 2575 m, 31 Aug 2006, Salicion herbaceae, between the liverwort Anthelia juratzkana (Anthelio-Salicetum herbaceae), leg. \& det. G. Corriol.

\section{Scutellinia trechispora f. brachyacantha Le Gal}

Previously published record: Lassueur (1988).

Collection cited: department of Ariège, France (without more precision), 28 Aug 1988.

Notes on habitat: The habitat is described as 'at $2400 \mathrm{~m}$ altitude, in mosses'. According to its altitude, in Ariège department, it is probably a true alpine collection. Nevertheless, we miss habitat informations.

Specimen examined: None.

Scutellinia vitreola Kullman

Previously published record: None.

Specimen examined: GC 03090205, site 24, 2 Sep 2003, Salicion herbaceae, leg. G. Corriol and T. Le Moal, det. G. Corriol. 
Basidiomycota

Agaricomycetideae

Agaricus campestris L.: Fr.

Previously published record: None.

Specimens examined: Not preserved, site 20, 23 Aug 2003, Arabidion caeruleae, leg. \& det. G. Corriol. - Not preserved, site 16, 20 Aug 2004, Arabidion caeruleae, leg. G. Corriol \& P. Burr, det. G. Corriol. - GC 05082901, site 26, 29 Aug 2005, Festucion supinae, leg. \& det. G. Corriol.

Agaricus comtulus Fr.

Previously published record: Vila \& al. (1998).

Collection cited: Site 7, 27 Aug 1997.

Notes on habitat: The habitat is described as 'between Dryas octopetala at 2220 m'. As Dryas octopetala is characteristic of both cryophilous and psychrophilous basophilous grasslands more ecological and floristical information is needed to say wether the habitat is Oxytropido-Elynion or Primulion intricatae.

Specimen examined: None.

Alnicola amarescens (Quél.) Romagn. (f. pyrenaica Ballarà prov.)

Previously published record: Ballarà (1997).

Collection cited: Site 35, 10 Jul 1995 and 17 Jul 1995.

Notes on habitat: The habitat is described as 'among Salix retusa at 2300 m'. It is probably Arabidion caeruleae.

Specimen examined: None.

Amanita nivalis Grev.

Previously published record: Vila \& al. (1998).

Collection cited: Site 7, 12 Aug 1997 and 27 Aug 1997.

Notes on habitat: The habitat is described as 'between Dryas octopetala and Salix retusa at 2300 m'. It may be Arabidion caeruleae or Oxytropido-Elynion. More ecological and floristical data are necessary.

Collection cited: Site 12, 14 Aug 1997.

Notes on habitat: The habitat is described as 'between Salix retusa and Salix herbacea at 2300 m'. It is probably Arabidion caeruleae.

Specimen examined: None.

Amanita oreina (J. Favre) R. Heim ex Bon

Previously published record: Ballarà (1997).

Collection cited: Site 34, 26 Aug 1995.

Notes on habitat: The habitat is described as 'among Salix herbacea and Alchemilla pentaphylla'. It is probably Salicion herbaceae.

Specimen examined: GC 05091421, site 17, 14 Sep 2005, Arabidion caeruleae, leg. G. Corriol \& N. Lavaupot, det. G. Corriol.

Arrhenia auriscalpium (Fr.) Fr.

Previously published record: Rocabruna \& al. (1994). 
Collection cited: Site 37, 17 Jul 1993.

Notes on habitat: The habitat is described as 'on mosses, ground, lichens at $2260 \mathrm{~m}$ '. One can't conclude on the habitat type without more ecological and floristical details.

Specimen examined: GC 03091004, site 17, 10 Sep 2003, Arabidion caeruleae, leg. \& det. G. Corriol. - GC 06081613, site 16, 16 Aug 2006, Arabidion caeruleae, leg. G. Corriol, C. Hannoire and E. Trouillard, det. G. Corriol.

Arrhenia glauca (Batsch) Bon \& Courtec.

Previously published record: Vila \& al. (1997).

Collection cited: Site 7, 16 Aug 1996.

Notes on habitat: The habitat is described as 'on of mosses at 2220 m'. One can't conclude on the habitat type without more ecological and floristical details.

Specimen examined: None.

Arrhenia griseopallida (Desm.: Fr.) Watling

Previously published record: Esteve-Raventós \& al. (1997).

Collection cited: Site 5, without date.

Notes on habitat: The habitat is described as 'on bryophytes in alpine pasture land, at 2250 m'. One can't conclude on the habitat type without more ecological and floristical details.

Specimens examined: Not preserved, site 21, 30 Aug 2002, Arabidion caeruleae, leg. \& det. G. Corriol. - Not preserved, site 24, 2 Sep 2003, Salicion herbaceae, leg. G. Corriol and T. Le Moal, det. G. Corriol. - NdM 03091908/2249-05, site 30, 19 Sep 2003, Oxytropido-Elynion, leg. N. de Munnik, det. G. Corriol. - GC 04091909, site 22, 19 Sep 2004, Salicion herbaceae, leg. \& det. G. Corriol. - GC 05091432, site 17, 14 Sep 2005, Arabidion caeruleae, leg. G. Corriol \& N. Lavaupot, det. G. Corriol.

Arrhenia lobata (Pers. : Fr.) Kühner \& Lamoure ex Redhead

Previously published record: Esteve-Raventós \& al. (1997).

Collection cited: Site 1, 31 Aug 1996.

Notes on habitat: The habitat is described as 'on bryophytes in very humid area at $2400 \mathrm{~m}$ '. It could be related to Scheuchzerio palustris-Caricetea fuscae or Cardamino-Montenion, but more ecological and floristical data are needed.

Specimen examined: Not preserved, site 19, 14 Sep 2005, Cardamino-Montenion, on bryophytes, leg. G. Corriol \& N. Lavaupot, det. G. Corriol.

Arrhenia obatra (J. Favre) Redhead, Lutzoni, Moncalvo \& Vilgalys

Previously published record: Esteve-Raventós \& al. (1997).

Collection cited: Site 1, 31 Aug 1996.

Notes on habitat: The habitat is described as 'on naked soil and between bryophytes in Salix herbacea communities on acidic soil at 2400 m'. It is probably Salicion herbaceae.

Specimen examined: GC 06081614, site 16, 16 Aug 2006, Arabidion caeruleae, leg. G. Corriol, C. Hannoire and E. Trouillard, det. G. Corriol.

Arrhenia velutipes (P.D. Orton) Redhead, Lutzoni, Moncalvo \& Vilgalys

Previously published record: Vila \& al. (1997), Vila \& al. (1998).

Collection cited: Site 7, 16 Aug 1996 and 27 Aug 1997.

Notes on habitat: The habitat is described as 'between Dryas octopetala and between mosses and Dryas octopetala, at 2220 m'. It may be Primulion intricatae, Oxytropido-Elynion or Arctostaphylo-Cetrarion. More ecological and floristical data are necessary.

Specimen examined: GC 06083103, site 13, Montagne de Cap de Long, altitude 2575 m, 31 Aug 2006, Eriophorion 
scheuchzeri, leg. \& det. G. Corriol.

Bolbitius vitellinus (Pers. : Fr.) Fr.

Previously published record: Vila \& al. (2001).

Collection cited: Site 7, 10 Aug 1999.

Notes on habitat: The habitat is described as 'between Dryas octopetala and Salix retusa at 2220 m'. It may be Arabidion caeruleae or Oxytropido-Elynion. More ecological and floristical data are necessary. Corriol.

Specimen examined: Not preserved, site 17, 14 Sep 2005, Nardion strictae, leg. G. Corriol \& N. Lavaupot, det. G.

Chalciporus piperatus (Bull. :Fr.) Bataille

Previously published record: Ballarà (1997).

Collection cited: Site 35, 20 Aug 1995.

Notes on habitat: The habitat is described as 'among Salix retusa at 2300 m'. It is probably Arabidion caeruleae.

Collection cited: Site 3, 25 Aug 1996.

Notes on habitat: The habitat is described as 'among Dryas octopetala and Vaccinium vitisideae at $2350 \mathrm{~m}$ '. This is an unuasual association of plants. It may be Arctostaphylo-Cetrarion, but more floristical and ecological data is needed.

Specimen examined: None.

\section{Clitocybe bresadoliana Singer var. bresadoliana}

Previously published record: Vila \& al. (1997).

Collection cited: Site 7, 16 Aug 1996.

Notes on habitat: The habitat is described as 'between Dryas octopetala at 2300 m'. As Dryas octopetala is characteristic of both cryophilous and psychrophilous basophilous grasslands more ecological and floristical information is needed to say wether the habitat is Oxytropido-Elynion or Primulion intricatae.

Specimen examined: None.

\section{Clitocybe bresadoliana var. dryadum Bon}

Previously published record: Bon \& Ballarà (1996).

Collection cited: Site 35, 10 Jul 1995.

Notes on habitat: The habitat is described as 'in the Carici-Salicetum retusae among Salix reticulata at $2300 \mathrm{~m}$ '. The Carici parviflorae-Salicetum retusae is the main Pyrenean association of basophilous snowbed from Arabidion caeruleae alliance, rich in dwarf willow.

Specimens examined: NdM 02081601/1947-13, site 31, 16 Aug 2002, Primulion intricatae with Dryas octopetala and Salix pyrenaica, leg. N. de Munnik, det. G. Corriol. - GC 02083001, site 21, 30 Aug 2002, Arabidion caeruleae, with Salix retusa, leg. \& det. G. Corriol. - NdM 03091906/2249-5, site 30, 19 Sep 2003, Oxytropido-Elynion, among Dryas octopetala, leg. N. de Munnik, det. G. Corriol. - GC 04091017, site 19, 27 Aug 2004, Arabidion caeruleae, leg. G. Corriol, P. Burr \& P. Hériveau, det. G. Corriol. - Not preserved, site 14, 22 Aug 2005, Primulion intricatae, leg. G. Corriol, C. Bergès \& A.-M. Labouche, det G. Corriol. - Not preserved, site 22, 9 Sep 2006, Oxytropido-Elynion, leg. \& det. G. Corriol.

Clitocybe candicans var. dryadicola (J. Favre) Lamoure

Previously published record: Esteve-Raventós \& al. (1997).

Collection cited: Site 5, 27 Aug 1996. 
Notes on habitat: The habitat is described as 'in alpine pasture land with patches of Salix pyrenaica and Dryas octopetala, at 2250 m'. It si probably Primulion intricatae.

Previously published record: Vila \& al. (1998).

Collection cited: Site 7, 12 Aug 1997.

Notes on habitat: The habitat is described as 'between Dryas octopetala at 2220 m'. As Dryas octopetala is characteristic of both cryophilous and psychrophilous basophilous grasslands more ecological and floristical information is needed to say wether the habitat is Oxytropido-Elynion or Primulion intricatae.

Other unpublished record: Not preserved, site 29, 3 Sep 2002, Oxytropido-Elynion, leg. \& det. N. de Munnik.

Specimen examined: None.

Clitocybe clavipes (Pers. : Fr.) P. Kumm.

Previously published record: Vila \& al. (1998).

Collection cited: Site 7, 27 Aug 1997.

Notes on habitat: The habitat is described as 'between Dryas octopetala and Salix retusa at 2300 m'. It may be Arabidion caeruleae or Oxytropido-Elynion. More ecological and floristical data are necessary.

Specimen examined: None.

Clitocybe costata Kühner et Romagn.

Previously published record: Vila \& al. (2001).

Collection cited: Site 7, 23 Aug 1999.

Notes on habitat: The habitat is described as 'between Dryas octopetala at 2220 m'. As Dryas octopetala is characteristic of both cryophilous and psychrophilous basophilous grasslands more ecological and floristical information is needed to say wether the habitat is Oxytropido-Elynion or Primulion intricatae.

Specimen examined: None.

\section{Clitocybe hebelomoides Lamoure}

Previously published record: Ballarà \& Escànez (1999).

Collection cited: Site 2, 3 Oct 1997.

Notes on habitat: The habitat is described as 'between Salix retusa, S. pyrenaica and mosses, 2250-2300 m'.It is probably Arabidion caeruleae.

Specimen examined: None.

Clitocybe langei Singer ex Hora

Previously published record: Ballarà (1997).

Collection cited: Site 2, 17 Sep 1995.

Notes on habitat: The habitat is described as 'among Dryas octopetala, Salix pyrenaica and $S$. retusa'. According to the presence of $S$. retusa it may be Arabidion caeruleae, but more information is needed.

Specimen examined: None.

Collybia alpicola (M. Bon \& Ballarà) Vila

Previously published record: Bon \& Ballarà (1996). 
Collection cited: Site 3, 19 Aug 1995.

Notes on habitat: The habitat is described as 'among Dryas octopetala at 2300 m'. As Dryas octopetala is characteristic of both cryophilous and psychrophilous basophilous grasslands more ecological and floristical information is needed to say wether the habitat is Oxytropido-Elynion or Primulion intricatae.

Previously published record: Vila \& al. (1998).

Collection cited: Site 7, 12 Aug 1997 and 27 Aug 1997.

Notes on habitat: The habitat is described as 'between Loiseuleria procumbens'.It is probably Loiseulerio-Vaccinion.

Previously published record: Ballarà \& Escànez (1999).

Collection cited: Site 8, 31 Aug 1997.

Notes on habitat: The habitat is described as 'between Salix retusa and Dryas octopetala, 2300-2400 m'. It may be Arabidion caeruleae or Oxytropido-Elynion. More ecological and floristical data are necessary.

Specimen examined: None.

Collybia dryophila (Bull. : Fr.) P. Kumm.

Previously published record: Vila \& al. (1997).

Collection cited: Site 7, 16 Aug 1996.

Notes on habitat: The habitat is described as 'between Dryas octopetala at 2220 m'. As Dryas octopetala is characteristic of both cryophilous and psychrophilous basophilous grasslands more ecological and floristical information is needed to say wether the habitat is Oxytropido-Elynion or Primulion intricatae.

Specimen examined: None.

Collybia fuscopurpurea (Pers. : Fr.) P. Kumm.

Previously published record: Ballarà \& Escànez (1999).

Collection cited: Site 8, 13 Jul 1997.

Notes on habitat: The habitat is described as 'between Vaccinium vitis-ideae, Dryas octopetala and Polytrichum sp., 2300-2400 m'. This is an unuasual association of plants. It may be Arctostaphylo-Cetrarion, but more floristical and ecological data is needed.

Specimen examined: None.

Collybia loiseleurietorum M.M. Moser, Gerhold \& Tobies

Previously published record: Bon \& Ballarà (1997).

Collection cited: Site 35, 4 Jul 1996.

Notes on habitat: The habitat is described as 'with Loiseleuria procumbens at 2350 m'. It is probably Loiseleurio-Vaccinion.

Previously published record: Vila \& al. (1997).

Collection cited: Site 7, 8 Aug 1996.

Notes on habitat: The habitat is described as 'between Loiseuleria procumbens and Dryas octopetala at $2300 \mathrm{~m}$ '. This is an unusual association of plants. It may be Arctostaphylo-Cetrarion, but more floristical and ecological data is needed.

Specimen examined: None.

Collybia pyrenaica Bon \& Ballarà

Previously published record: Bon \& Ballarà (1997). 
Collection cited: Site 35, 24 Aug 1996.

Notes on habitat: The habitat is described as 'with Loiseleuria procumbens at 2350 m'. It is probably Loiseleurio-Vaccinion.

Notes on distribution : This taxon, close to C. alpicola (M. Bon \& Ballarà) Vila seems so far, to be endemic to the Pyrenees alpine zone.

Specimen examined: None.

Conocybe aff. ambigua (Kühner ex) Watling, "f. microsporic"

Previously published record: None.

Taxonomic notes : This collection matches well with C. ambigua except for the spores (9-11,5 x 6,5-7 $\mu \mathrm{m}$, with 1-2 $\mu \mathrm{m}$ large pore) which are too short. No other closer Conocybe species have been found neither in Bon (1992) nor in Meusers (1996).

Specimen examined: GC 03082806, site 16, 28 Aug 2003, Arabidion caeruleae, leg. \& det. G. Corriol.

\section{Conocybe magnicapitata P.D. Orton}

Previously published record: None.

Taxonomic notes : This collection only differs from the description of Watling (1982) and Bon (1992) by the occurence of clamp-connections.

Specimen examined: GC 05091445, site 19, 10 Sep 2004, Arabidion caeruleae, leg. \& det. G. Corriol.

Conocybe ochracea f. alpina J. Favre inval.

Previously published record: None.

Taxonomic notes : Our collections match very well the description by Favre (1955). Bon (1992) treated this taxon as a minute form with smaller spores of C. kuehneriana Sing.

Specimens examined: GC 04082003, site 16, 20 Aug 2004, Arabidion caeruleae, leg. G. Corriol \& P. Burr, det. G. Corriol. - Not preserved, site 19, 10 Sep 2004, Arabidion caeruleae, leg. \& det. G. Corriol.

Conocybe pseudopilosella (Kühner) Kühner \& Watling

Previously published record: None.

Specimen examined: Not preserved, site 19, 10 Sep 2004, Arabidion caeruleae, leg. \& det. G. Corriol.

Conocybe tenera (Schaeff.: Fr.) Fayod

Previously published record: None.

Specimen examined: Not preserved, site 21, 30 Aug 2002, Arabidion caeruleae, leg. \& det. G. Corriol.

\section{Coprinus martinii P.D. Orton}

Previously published record: None.

Specimen examined: GC 04091003, site 19, 10 Sep 2004, Caricion incurvae, between bryophytes, Carex bicolor and C. lepidocarpa, leg. \& det. G. Corriol. - Not preserved, site 19, 14 Sep 2005, Caricion incurvae, between bryophytes, Carex bicolor and C. lepidocarpa, leg. G. Corriol \& N. Lavaupot, leg. G. Corriol.

Coprinus patouillardii Quél.

Previously published record: Rocabruna \& al. (1994).

Collection cited: catalan Pyrenees (without more precision), 15 Jul 1993.

Notes on habitat: The habitat is described as 'on cow dung, at 2260 m'. Coprophilous. Specimen examined: None. 


\section{Cortinarius albonigrellus J. Favre}

Previously published record: Bon \& Ballarà (1995) under « forma ? ».

Collection cited: Site 2, 19 Sep 1994.

Notes on habitat: The habitat is described as 'in the Carici-Salicetum retusae among Salix retusa and $S$. reticulata at $2050 \mathrm{~m}$ '. The altitude given by the authors is surprisingly low, but the plant association is typical of Pyrenean Arabidion caeruleae snow-bed communities rich in dwarf willows.

Previously published record: Bon \& Ballarà (1997).

Collection cited: Site 25, 18 Sep 1996.

Notes on habitat: The habitat is described as 'among Salix herbacea at 2700 m'. According to the acidic rocks of this site, it is probably Salicion herbaceae.

Specimen examined: GC 05091418, site 19, 14 Sep 2005, Arabidion caeruleae, leg. G. Corriol \& N. Lavaupot, det. G. Corriol., conf. D. Lamoure.

\section{Cortinarius alpicola (Bon) Bon}

Previously published record: Bon \& Ballarà (1997).

Collection cited: Site 23, 2 Oct 1992.

Notes on habitat: The habitat is described as 'alpine calcareous grassland at about $2400 \mathrm{~m}$ '. According to exposure and calcareous soil, it may be Primulion intricatae, but more ecological and floristical data are necessary.

Previously published record: Bon \& Ballarà (1997).

Collection cited: Site 3, 25 Aug 1996.

Notes on habitat: The habitat is described as 'among Dryas octopetala at about 2350 m'. It may be Primulion intricatae, Oxytropido-Elynion or Arctostaphylo-Cetrarion. More ecological and floristical data are necessary.

Previously published record: Vila \& al. (1998).

Collection cited: Site 7, 27 Aug 1997.

Notes on habitat: The habitat is described as 'between Dryas octopetala and Salix retusa at 2300 m'. It may be Arabidion caeruleae or Oxytropido-Elynion. More ecological and floristical details are necessary.

Previously published record: Vila \& al. (1998).

Collection cited: Site 7, 27 Aug 1997.

Notes on habitat: The habitat is described as 'between Salix herbacea at 2400 m'. It is a snowbed community from Salicetea herbaceae, but without more floristical or stational information, we cannot choose between the Salicion herbaceae or Arabidion caeruleae alliances.

Previously published record: Vila \& al. (2001).

Collection cited: Site 12, 7 Aug 1999.

Notes on habitat: The habitat is described as 'between Salix herbacea and S. retusa at 2300 m'. It is probably Arabidion caeruleae.

Specimen examined: None.

\section{Cortinarius alpicola var. salicis-herbaceae (Bon) Bon}

Previously published record: Bon \& Ballarà (1997).

Collection cited: Site 34, 26 Aug 1995.

Notes on habitat: The habitat is described as 'with Salix herbacea'. According to the acidic rocks of this site, it is probably Salicion herbaceae.

Specimen examined: GC 03090201, site 24, 2 Sep 2003, Salicion herbaceae, leg. G. Corriol and T. Le Moal, det. 
G. Corriol. - GC 05083102, site 33, 31 Aug 2005, Salicion herbaceae, with Salix herbacea, leg G. Corriol, H. Chevallier, T. Guillonet \& N. Point, det. G. Corriol.

Cortinarius anomalus (Fr. : Fr.) Fr. var. anomalus

Previously published record: None.

Specimen examined: Not preserved, site 20, 23 Aug 2003, Arabidion caeruleae, leg. \& det. G. Corriol.

\section{Cortinarius anomalus var. calcialpinus Bon}

Previously published record: Bon \& Ballarà (1996).

Collection cited: Site 3, 19 Aug 1995.

Notes on habitat: The habitat is described as 'among Dryas octopetala at 2300 m'. It may be Primulion intricatae, Oxytropido-Elynion or Arctostaphylo-Cetrarion. More ecological and floristical data are necessary.

Previously published record: Esteve-Raventós \& al. (1997).

Collection cited: Site 5, 14 Aug 1996.

Notes on habitat: The habitat is described as 'in alpine pasture land, on limestones, with Salix pyrenaica, at $2250 \mathrm{~m}$ '. It is probably Primulion intricatae.

Previously published record: Vila \& al. (1998).

Collection cited: Site 7, 12 Aug 1997 and 27 Aug 1997.

Notes on habitat: The habitat is described as 'between Dryas octopetala and Salix retusa at 2200-2300 m'. It may be Arabidion caeruleae or Oxytropido-Elynion. More ecological and floristical details are necessary.

Specimen examined: None.

Cortinarius cedriolens (M.M. Moser) M.M. Moser

Previously published record: None.

G. Corriol

Specimen examined: GC 05091408, site 17, 14 Sep 2005, Arabidion caeruleae, leg. G. Corriol \& N. Lavaupot, det.

\section{Cortinarius chamaesalicis Bon}

Previously published record: Vila \& al. (1998).

Collection cited: Site 12, 14 Aug 1997.

Notes on habitat: The habitat is described as 'between Salix herbacea at 2350 m'. It certainly is a snow bed of the Salicetea herbaceae class, but without more floristical or stational information, we cannot choose between the Salicion herbaceae or Arabidion caeruleae alliances.

Specimen examined: None.

\section{Cortinarius chrysomalus Lamoure}

Previously published record: Esteve-Raventós \& al. (1997).

Collection cited: Site 1, 31 Aug 1996.

Notes on habitat: The habitat is described as 'in carpets of Salix herbacea, on siliceous substrate at 2400 m'. It is probably Salicion herbaceae.

Taxonomic note: In our collection, we could not see the basal violet mycelium on that collection, and the spores were a bit larger $[8-10(11,5)-5,5-6,5 \mu \mathrm{m}]$ than in the litterature. Nevertheless, the other characters including the yellow veil and strongly ornemented apex of spores match well.

Specimen examined: GC 04091913, site 22, 19 Sep 2004, Salicion herbaceae, leg. \& det. G. Corriol. 


\section{Cortinarius claricolor var. subturmalis Bon \& Gaugué}

Previously published record: Bon \& Ballarà (1997).

Collection cited: Site 8, 25 Aug 1996.

Notes on habitat: The habitat is described as 'among Dryas octopetala at about 2375 m'. It may be Primulion intricatae, Oxytropido-Elynion or Arctostaphylo-Cetrarion. More ecological and floristical data are necessary.

Specimen examined: None.

\section{Cortinarius croceoconus Fr.}

Previously published record: Bon \& Ballarà (1995).

Collection cited: Site 38, 10 Sep 1994.

Notes on habitat: The habitat is described as 'in the Salici-Anthelietum between Salix herbacea at $2350 \mathrm{~m}$ '. The Anthelio juratzkanae-Salicetum herbaceae (which is supposed to be the 'Salici-Anthelietum' from the authors) is the main Pyrenean association of acidophilous snowbed from Salicion herbaceae alliance, rich in Salix herbacea.

Specimen examined: None.

Cortinarius delibutus f. dryadicola Ballarà \& Escànez (=C. illibatus f. dryadicola Bon \& Ballarà prov. $=$ C. delibutus f. saturatoides ss. M. Bon \& Ballarà)

Previously published record: Bon \& Ballarà (1996, 1997).

Collection cited: Site 3, 19 Aug 1995, 18 Aug 1996 and 25 Aug 1996.

Notes on habitat: The habitat is described as 'among Dryas octopetala at about 2300 m'. It may be Primulion intricatae, Oxytropido-Elynion or Arctostaphylo-Cetrarion. More ecological and floristical data are necessary.

Previously published record: Ballarà \& Escànez (1999).

Collection cited: Site 8, 31 Aug 1997.

Notes on habitat: The habitat is described as 'between Dryas octopetala, 2300 m'. It may be Primulion intricatae, Oxytropido-Elynion or Arctostaphylo-Cetrarion. More ecological and floristical data are necessary.

Previously published record: Vila \& al. (2001).

Collection cited: Site 7, 10 Aug 1999.

Notes on habitat: The habitat is described as 'between Dryas octopetala and Salix retusa at 2220 m'. It may be Arabidion caeruleae or Oxytropido-Elynion. More ecological and floristical details is needed.

Specimen examined: None.

\section{Cortinarius diasemospermus Lamoure}

Previously published record: Vila \& al. (1998).

Collection cited: Site 12, 14 Aug 1997.

Notes on habitat: The habitat is described as 'between Salix herbacea at 2350 m'. It certainly is a snow bed of the Salicetea herbaceae class, but without more floristical or stational information, we cannot choose between the Salicion herbaceae or Arabidion caeruleae alliances.

Specimen examined: GC 05091407, site 17, 14 Sep 2005, Arabidion caeruleae, leg. G. Corriol \& N. Lavaupot, det. G. Corriol. 
Cortinarius favrei M.M. Moser ex Henderson

Previously published record: Bon \& Ballarà (1996).

Collection cited: Site 34, 26 Aug 1995.

Notes on habitat: The habitat is described as 'among Salix herbacea at 2400 m'. It is probably Salicion herbaceae.

Previously published record: Vila \& al. (1998).

Collection cited: Site 12, 2 Aug 1997.

Notes on habitat: The habitat is described as 'between Salix retusa at 2350 m'. It is probably Arabidion caeruleae.

Specimen examined: GC 06080502, site 13, small lake under the Maniportet glacier, altitude 2680 m, 5 Aug 2006, Salicion herbaceae, leg. \& det. G. Corriol..

Cortinarius favrexilis Bon (forma?)

Previously published record: Bon \& Ballarà (1995).

Collection cited: Site 38, 10 Sep 1994.

Notes on habitat: The habitat is described as 'in the Salici-Anthelietum between Salix herbacea at $2350 \mathrm{~m}$ '. The Anthelio juratzkanae-Salicetum herbaceae (the 'Salici-Anthelietum' from the authors) is the main Pyrenean association of acidophilous snowbed from Salicion herbaceae alliance, rich in Salix herbacea.

Specimen examined: None.

\section{Cortinarius gausapatus Fr}

Previously published record: None.

Specimen examined: GC 06081301, Troumouse circus (at the east of site 14), altitude 2300 m, 13 Aug 2006, Arabidion caeruleae, leg. \& det. G. Corriol.

Cortinarius hinnuleus Fr. (f. pyrenaica M. Bon et Ballarà prov.)

Previously published record: Bon \& Ballarà (1996).

Collection cited: Site 2, 15 Jul 1995 and 16 Jul 1995.

Notes on habitat: The habitat is described as 'among Salix pyrenaica'. It is more likely subalpine Primulion intricatae, but more information is needed.

Specimen examined: None.

Cortinarius hinnuleus var. favreanus Bon

Previously published record: Vila \& al. (2001).

Collection cited: Site 7, 10 Aug 1999.

Notes on habitat: The habitat is described as 'between Dryas octopetala and Salix retusa at 2220 m'. It may be Arabidion caeruleae or Oxytropido-Elynion. More ecological and floristical details are necessary.

Specimen examined: GC 04091008, site 17, 10 Sep 2004, Arabidion caeruleae, leg. G. Corriol, det. D. Lamoure.

Cortinarius hinnuleus f. subtypicus Favre ex Nespiak

Previously published record: Bon \& Ballarà (1996).

Collection cited: Site 34, 26 Aug 1995. 
Notes on habitat: The habitat is described as 'among Salix herbacea at 2400 m'. It is probably Salicion herbaceae.

Specimens examined: Not preserved, site 22, 9 Sep 2006, Salicion herbaceae, leg. \& det. G. Corriol. - GC 06081001, Estom Soubiran, high Lutour valley (at the east of site 24), altitude 2450 m, 10 Aug 2006, Salicion herbaceae, leg. \& det. G. Corriol.

\section{Cortinarius infractus var. olivellus M.M. Moser}

Previously published record: Bon \& Ballarà (1997).

Collection cited: Site 3, 25 Aug 1996.

Notes on habitat: The habitat is described as 'among Dryas octopetala, 2300-2350 m'. It may be Primulion intricatae, Oxytropido-Elynion or Arctostaphylo-Cetrarion. More ecological and floristical data are necessary.

Specimen examined: None.

\section{Cortinarius inops J. Favre}

Previously published record: Ballarà (1997).

Collection cited: Site 35, 20 Jul 1996.

Notes on habitat: The habitat is described as 'among Salix reticulata and S. retusa at 2300 m'. It is probably Arabidion caeruleae.

Specimen examined: GC 06081609, site 16, 16 Aug 2006, Arabidion caeruleae, leg. G. Corriol, C. Hannoire and E. Trouillard, det. G. Corriol.

\section{Cortinarius laevipileus J. Favre}

Previously published record: Vila \& al. (1998) (under f. microsporus prov.), Vila \& al. (2001).

Collection cited: Site 7, 27 Aug 1997 and 10 Aug 1999.

Notes on habitat: The habitat is described as 'between Dryas octopetala and Salix retusa at 2220 m'. It may be Arabidion caeruleae or Oxytropido-Elynion. More ecological and floristical data are necessary.

Specimen examined: None.

Cortinarius lamourei Bon \& Jamoni

Previously published record: None.

Collection cited:

Notes on habitat: The habitat is described as "

D. Lamoure.

Specimen examined: GC 05091417, site 19, 14 Sep 2005, Arabidion caeruleae, leg. G. Corriol \& N. Lavaupot, det.

Cortinarius minutalis (J. Favre) Lamoure

Previously published record: Bon \& Ballarà (1996).

Collection cited: Site 35, 20 Aug 1995.

Notes on habitat: The habitat is described as 'among Salix reticulata and S. retusa at 2300 m'. It si probably Arabidion caeruleae.

Specimen examined: GC 04091911, site 22, 19 Sep 2004, Salicion herbaceae, leg. \& det. G. Corriol.

\section{Cortinarius minutulus J. Favre}

Previously published record: Vila \& al. (2001).

Collection cited: Site 7, 10 Aug 1999. 
Notes on habitat: The habitat is described as 'between Dryas octopetala and Salix retusa at 2220 m'. It may be Arabidion caeruleae or Oxytropido-Elynion. More ecological and floristical data are necessary.

Specimen examined: None.

\section{Cortinarius paleifer Svrček}

Previously published record: Vila \& al. (2001).

Collection cited: Site 12, 7 Aug 1999.

Notes on habitat: The habitat is described as 'between Salix herbacea at 2350 m'. It certainly is a snow bed of the Salicetea herbaceae class, but without more floristical or stational information, we cannot choose between the Salicion herbaceae or Arabidion caeruleae alliances.

Specimen examined: None.

\section{Cortinarius phaeochrous J. Favre}

Previously published record: Bon \& Ballarà (1995).

Collection cited: Site 2, 19 Sep 1994.

Notes on habitat: The habitat is described as 'in the Carici-Salicetum retusae among Salix retusa and $S$. reticulata at $2050 \mathrm{~m}$ '. The altitude given by the authors is surprisingly low, but the plant association is typical of Pyrenean Arabidion caeruleae snow-bed communities rich in dwarf willows.

Previously published record: Vila \& al. (1997).

Collection cited: Site 7, 16 Aug 1996.

Notes on habitat: The habitat is described as 'between Salix retusa and Dryas octopetala at 2220 m'. It may be Arabidion caeruleae or Oxytropido-Elynion. More ecological and floristical details are necessary.

Specimen examined: None.

\section{Cortinarius phaeopygmaeus J. Favre}

Previously published record: Bon \& Ballarà (1995).

Collection cited: Site 38, 10 Sep 1994.

Notes on habitat: The habitat is described as 'in the Salici-Anthelietum between Salix herbacea at 2350 m'. The Anthelio juratzkanae-Salicetum herbaceae (the 'Salici-Anthelietum' from the authors) is the main Pyrenean association of acidophilous snowbed from Salicion herbaceae alliance, rich in Salix herbacea.

Specimen examined: GC 04091913, site 22, 19 Sep 2004, Salicion herbaceae, leg. \& det. G. Corriol.

\section{Cortinarius polaris Høiland}

Previously published record: Bon \& Ballarà (1996).

Collection cited: Site 34, 26 Aug 1995.

Notes on habitat: The habitat is described as 'among Salix herbacea at 2400 m'. It is probably Salicion herbaceae.

Previously published record: Vila \& al. (1998).

Collection cited: Site 7, 27 Aug 1997.

Notes on habitat: The habitat is described as 'between Dryas octopetala and Salix retusa at 2300 m'. It may be Arabidion caeruleae or Oxytropido-Elynion. More ecological and floristical details are necessary.

Specimen examined: None. 
Cortinarius pratensis (Bon \& Gaugué) Høiland (f. salicis-herbaceae M. Bon \& Cheype prov.)

Previously published record: Vila \& al. (1998).

Collection cited: Site 7, 27 Aug 1997.

Notes on habitat: The habitat is described as 'between Salix herbacea at 2400 m'. It is a snowbed community from Salicetea herbaceae, but without more floristical or stational information, we cannot choose between the Salicion herbaceae or Arabidion caeruleae alliances.

Specimen examined: None.

Cortinarius saniosus (Fr. : Fr.) Fr. (f. praecox M. Bon \& Ballarà prov.)

Previously published record: Bon \& Ballarà (1996).

Collection cited: Site 35, 17 Jul 1995.

Notes on habitat: The habitat is described as 'among Dryas octopetala at 2300 m'. It may be Primulion intricatae, Oxytropido-Elynion or Arctostaphylo-Cetrarion. More ecological and floristical data are necessary.

Specimen examined: None.

\section{Cortinarius scotoides J. Favre}

Previously published record: None.

G. Corriol.

Specimen examined: Not preserved, site 24, 2 Sep 2003, Salicion herbaceae, leg. G. Corriol and T. Le Moal, det.

\section{Cortinarius stenospermus Lamoure}

Previously published record: Bon \& Ballarà (1995) under « forma ? ».

Collection cited: Site 38, 10 Sep 1994.

Notes on habitat: The habitat is described as 'in the Salici-Anthelietum between Salix herbacea at 2350 m'. The Anthelio juratzkanae-Salicetum herbaceae (the 'Salici-Anthelietum' from the authors) is the main Pyrenean association of acidophilous snowbed from Salicion herbaceae alliance, rich in Salix herbacea.

Previously published record: Vila \& al. (1998).

Collection cited: Site 7, 12 Aug 1997.

Notes on habitat: The habitat is described as 'between Dryas octopetala and Salix retusa at 2220 m'. It may be Arabidion caeruleae or Oxytropido-Elynion. More ecological and floristical details are necessary.

Specimen examined: None.

Cortinarius subtilior J. Favre

Previously published record: Ballarà (1997).

Collection cited: Site 34, 24 Aug 1996.

Notes on habitat: The habitat is described as 'among Salix herbacea at about 2400 m'. It is probably Salicion herbaceae.

Specimen examined: None.

\section{Cortinarius subtorvus Lamoure}

Previously published record: Bon \& Ballarà (1996).

Collection cited: Site 2, 16 Jul 1995.

Notes on habitat: The habitat is described as 'with Salix reticulata and S. retusa at 2100 m' 
and 'among Dryas octopetala at 2300 m'. For the first habitat, the altitude given by the authors is surprisingly low, but the association of willows is characteristic of Arabidion caeruleae snow-bed community. For the second one, it may be Primulion intricatae, Oxytropido-Elynion or ArctostaphyloCetrarion. More ecological and floristical data are necessary.

Previously published record: Bon \& Ballarà (1996).

Collection cited: Site 35, 16 Sep 1995.

Notes on habitat: The habitat is described as 'between Dryas octopetala and Salix reticulata at 2300 m'. It may be Arabidion caeruleae or Oxytropido-Elynion. More ecological and floristical details are necessary.

Specimen examined: None.

\section{Cortinarius tenebricus J. Favre}

Previously published record: Ballarà (1997).

Collection cited: Site 35, 20 Jul 1996.

Notes on habitat: The habitat is described as 'among Salix retusa at 2300 m'. It is probably Arabidion caeruleae.

Specimen examined: Not preserved, site 17, 10 Sep 2003, Arabidion caeruleae, leg. \& det. G. Corriol.

Cortinarius violaceorubens Moënne-Locc. \& Reumaux (alpine form)

Previously published record: Bon \& Ballarà (1997).

Collection cited: Site 8, 25 Aug 1996.

Notes on habitat: The habitat is described as 'among Dryas octopetala at about 2375 m'. It may be Primulion intricatae, Oxytropido-Elynion or Arctostaphylo-Cetrarion. More ecological and floristical data are necessary.

Specimen examined: None.

Cystoderma carcharias (Pers. : Fr.) Fayod var. alpinum prov.

Previously published record: None.

Taxonomic notes: $C$. carcharias is usually known as an acidophilous forest species, from lowland to subalpine stage. Our collection from a dense alpine acidic grassland with Festuca eskia at $2320 \mathrm{~m}$, differs from the type by the lack of smell. We have another collection (GC 04091023) from a grassland at 2250 which may be subalpine. We propose a provisional name for this inodorous form, waiting to study more collections.

Specimen examined: Not preserved, site 17, 14 Sep 2005, Nardion strictae, leg. G. Corriol \& N. Lavaupot, det. G. Corriol. - GC 04091023, Les Sarradets, Gavarnie, France, 10 Sep 2004, Nardion strictae subalpine grassland at $2250 \mathrm{~m}$, leg. $\&$ det. G. Corriol.

Cystolepiota seminuda (Lasch : Fr.) M. Bon

Previously published record: Vila \& al. (2001).

Collection cited: Site 3, 22 Aug 1999.

Notes on habitat: The habitat is described as 'on decomposing leaves of Dryas octopetala and Salix reticulata at 2240 m'. It may be Arabidion caeruleae or Oxytropido-Elynion. More ecological and floristical details are necessary.

Specimen examined: None.

Dermoloma pseudocuneifolium Herink ex Bon

Previously published record: Vila \& Esteve-Raventós (1998). 
Collection cited: Site 7, 27 Aug 1997.

Notes on habitat: The habitat is described as 'between Dryas octopetala and Salix retusa at 2220 m'. It may be Arabidion caeruleae or Oxytropido-Elynion. More ecological and floristical details are necessary.

Specimen examined: None.

Entoloma alpicola (J. Favre) Noordel.

Previously published record: Bon \& Ballarà (1996).

Collection cited: Site 34, 26 Aug 1995.

Notes on habitat: The habitat is described as 'among Salix herbacea at about 2400 m'. It is probably Salicion herbaceae.

Specimen examined: None.

Entoloma asprellum (Fr.) Fayod

Previously published record: Vila \& al. (2001).

Collection cited: Site 12, 7 Aug 1999.

Notes on habitat: The habitat is described as 'between Salix herbacea at 2350 m'. It certainly is a snow bed of the Salicetea herbaceae class, but without more floristical or stational information, we cannot choose between the Salicion herbaceae or Arabidion caeruleae alliances.

Specimen examined: None.

Entoloma anatinum (Lasch : Fr.) Donk

Previously published record: None.

Specimen examined: GC 01083004, site 21, 30 Aug 2002, Arabidion caeruleae, leg. \& det. G. Corriol.

Entoloma atromarginatum (Romagn. \& J. Favre) Zschiesch.

Previously published record: None.

Specimen examined: GC 03082807, site 16, 28 Aug 2003, Arabidion caeruleae, leg. \& det. G. Corriol. - Not preserved, site 17, 10 Sep 2003, Arabidion caeruleae, leg. \& det. G. Corriol. - GC 05091448, site 17, 14 Sep 2005, Arabidion caeruleae, leg. G. Corriol \& N. Lavaupot, det. G. Corriol.

\section{Entoloma caesiocinctum Kühner}

Previously published record: Bon \& Ballarà (1997).

Collection cited: Site 3, 18 Aug 1996.

Notes on habitat: The habitat is described as 'with Dryas octopetala and Salix pyrenaica at 2300 m'. It is probably Primulion intricatae.

Previously published record: Bon \& Ballarà (1997).

Collection cited: Site 8, 25 Aug 1996.

Notes on habitat: The habitat is described as 'among Dryas octopetala at $2350 \mathrm{~m}$ '. It may be Primulion intricatae, Oxytropido-Elynion or Arctostaphylo-Cetrarion. More ecological and floristical data are necessary.

Specimen examined: None.

Entoloma catalaunicum (Singer) Noordel.

Previously published record: Esteve-Raventós \& al. (1997).

Collection cited: Site 5, 14 Aug 1996. 
Notes on habitat: The habitat is described as 'in alpine pasture land in calcareous substrate, at 2200-2300 m'. It may be Primulion intricatae, but more ecological and floristical data are needed. Specimen examined: Not preserved, site 21, 30 Aug 2002, Arabidion caeruleae, leg. \& det. G. Corriol.

Entoloma chalybaeum (Fr. : Fr.) Noordel.

Previously published record: Esteve-Raventós \& al. (1997).

Collection cited: Site 5, 14 Aug 1996.

Notes on habitat: The habitat is described as 'in alpine pasture land in basic soil, at 2200-2300 m'. It may be Primulion intricatae, but more ecological and floristical data are needed.

Previously published record: Vila \& al. (1998).

Collection cited: Site 7, 27 Aug 1997.

Notes on habitat: The habitat is described as 'between Dryas octopetala and Salix retusa at 2300 m'. It may be Arabidion caeruleae or Oxytropido-Elynion. More ecological and floristical details are necessary.

Specimen examined: Not preserved, site 24, 2 Sep 2003, Salicion herbaceae, leg. G. Corriol and T. Le Moal, det. G. Corriol. - Not preserved, site 22, 9 Sep 2006, Salicion herbaceae, leg. \& det. G. Corriol.

\section{Entoloma chloropolium (Fr.) M.M. Moser}

Previously published record: Vila \& al. (2001).

Collection cited: Site 7, 10 Aug 1999.

Notes on habitat: The habitat is described as 'between Dryas octopetala and Salix retusa at 2220 m'. It may be Arabidion caeruleae or Oxytropido-Elynion. More ecological and floristical details are necessary.

Specimen examined: None.

Entoloma clandestinum var. acutissimum (J. Favre) Horak

Previously published record: None.

Taxonomic notes: Our second collection did not show an acute umbo, but the other characters match well with a minute alpine form of E. clandestinum.

Specimen examined: GC 03082802, site 16, 28 Aug 2003, Arabidion caeruleae, leg. \& det. G. Corriol. - GC 05091403, site 17, 14 Sep 2005, Arabidion caeruleae, leg. G. Corriol \& N. Lavaupot, det. G. Corriol.

Entoloma conferendum (Britzelm.) Noordel.

Previously published record: Bon \& Ballarà (1996).

Collection cited: Site 34, 10 Sep 1994 and 26 Aug 1995.

Notes on habitat: The habitat is described as 'among Salix herbacea'. It is probably Salicion herbaceae.

Previously published record: Esteve-Raventós \& al. (1997).

Collection cited: Site 5, 14 Aug 1996.

Notes on habitat: The habitat is described as 'in alpine pasture land in calcareous substrate, at 2200-2300 m'. It may be Primulion intricatae, but more ecological and floristical data are needed.

Previously published record: Vila \& al. (1998).

Collection cited: Site 12, 14 Aug 1997.

Notes on habitat: The habitat is described as 'between Salix herbacea and Loiseuleria procumbens at $2450 \mathrm{~m}$ '. In spite of this unusual association of plants, it may be a snow-bed community of the Salicion herbaceae on account of the acidic station (Loiseuleria procumbens) and the highly characteristic Salix herbacea. 
Previously published record: Vila \& al. (2001).

Collection cited: Site 4, 28 Sep 1999.

Notes on habitat: The habitat is described as 'between Salix herbacea at 2210 m'. It certainly is a snow bed of the Salicetea herbaceae class, but without more floristical or stational information, we cannot choose between the Salicion herbaceae or Arabidion caeruleae alliances. G. Corriol.

Specimen examined: Not preserved, site 19, 14 Sep 2005, Arabidion caeruleae, leg. G. Corriol \& N. Lavaupot, det.

Entoloma conferendum var. incrustatum (Largent \& Thiers) Noordel. \& Hauskn.

Previously published record: None.

Notes on distribution: According to Noordeloos (2004), this taxon would only be known from Austrian Alps in Europe. E. conferendum is easily recognisable in the field and probably not often checked under the microscope. In this, the variety with incrusting pigment may be only unappreciated. G. Corriol.

Specimen examined: GC 05091443, site 17, 14 Sep 2005, Arabidion caeruleae, leg. G. Corriol \& N. Lavaupot, det.

Entoloma excentricum Bres.

Previously published record: Esteve-Raventós \& al. (1997).

Collection cited: Site 5, 14 Aug 1996.

Notes on habitat: The habitat is described as 'in alpine pasture land in calcareous substrate, at 2200-2300 m'. It may be Primulion intricatae, but more ecological and floristical data are needed. Specimen examined: None.

Entoloma exile (Fr. : Fr.) Hesler

Previously published record: Vila \& al. (1998), under f. nuriense Vila \& Esteve-Rav. prov.

Collection cited: Site 7, 12 Aug 1997.

Notes on habitat: The habitat is described as 'between Dryas octopetala and Salix retusa at 2220 and 2300 m'. It may be Arabidion caeruleae or Oxytropido-Elynion. More ecological and floristical details are necessary.

Previously published record: Vila \& al. (2001), under f. exile.

Collection cited: Site 12, 7 Aug 1999.

Notes on habitat: The habitat is described as 'between Salix herbacea at 2350 m'. It certainly is a snow bed of the Salicetea herbaceae class, but without more floristical or stational information, we cannot choose between the Salicion herbaceae or Arabidion caeruleae alliances.

Previously published record: Vila \& al. (2001), under f. exile.

Collection cited: Site 3, 22 Aug 1999.

Notes on habitat: The habitat is described as 'between Dryas octopetala and Salix reticulata at 2240 m'. It may be Arabidion caeruleae or Oxytropido-Elynion. More ecological and floristical details are necessary.

Specimen examined: None.

Entoloma formosum (Fr. : Fr.) P. Kumm.

Previously published record: Ballarà (1997).

Collection cited: Site 8, 13 Aug 1996.

Notes on habitat: The habitat is described as 'among Salix reticulata, 2300-2400 m'. It is probably Arabidion caeruleae. 
Specimen examined: None.

\section{Entoloma fuscotomentosum F.H. Møller}

Previously published record: Bon \& Ballarà (1997).

Collection cited: Site 3, 25 Aug 1996.

Notes on habitat: The habitat is described as 'with Dryas octopetala and Vaccinium vitis-ideae at $2350 \mathrm{~m}$ '. It may be Arctostaphylo-Cetrarion, but more floristical and ecological data is needed.

Previously published record: Vila \& al. (1998).

Collection cited: Site 7, 12 Aug 1997.

Notes on habitat: The habitat is described as 'between Dryas octopetala and Salix retusa at 2300 m'. It may be Arabidion caeruleae or Oxytropido-Elynion. More ecological and floristical details are necessary.

Specimen examined: None.

Entoloma griseocyaneum (Fr. : Fr.) P. Kumm.

Previously published record: Ballarà (1997).

Collection cited: Site 2, 16 Jul 1995.

Notes on habitat: The habitat is described as 'with $S$. retusa between 2300 and 2350 m'. It is probably Arabidion caeruleae.

Previously published record: Esteve-Raventós \& al. (1997).

Collection cited: Site 5, 14 Aug 1996.

Notes on habitat: The habitat is described as 'in alpine pasture land on basic soil, at 2200-2300 m'. It may be Primulion intricatae, but more ecological and floristical data are needed.

Previously published record: Vila \& al. (1998).

Collection cited: Site 7, 27 Aug 1997.

Notes on habitat: The habitat is described as 'between Dryas octopetala and Salix retusa at 2300 m'. It may be Arabidion caeruleae or Oxytropido-Elynion. More ecological and floristical details are necessary. G. Corriol.

Specimen examined: Not preserved, site 17, 14 Sep 2005, Arabidion caeruleae, leg. G. Corriol \& N. Lavaupot, det.

Entoloma griseorubidum Kühner ex Noordel.

Previously published record: None.

Specimen examined: GC 05091438, site 17, 14 Sep 2005, Arabidion caeruleae, leg. G. Corriol \& N. Lavaupot, det. G. Corriol.

Entoloma incanum (Fr. : Fr.) Hesler

Previously published record: Bon \& Ballarà (1996).

Collection cited: Site 3, 19 Aug 1995. - Site 35, 20 Aug 1995.

Notes on habitat: The habitat is described as 'among Salix reticulata at $2200 \mathrm{~m}$ ' and 'among Salix reticulata and S. retusa at $2300 \mathrm{~m}^{\prime}$. Both are probably Arabidion caeruleae.

Previously published record: Vila \& al. (1997).

Collection cited: Site 7, 8 Aug 1996.

Notes on habitat: The habitat is described as 'between Dryas octopetala and Salix retusa at 2220 m'. It may be Arabidion caeruleae or Oxytropido-Elynion. More ecological and floristical details are necessary.

Previously published record: Esteve-Raventós \& al. (1997). 
Collection cited: Site 5, 14 Aug 1996.

Notes on habitat: The habitat is described as 'in alpine pasture land on basic soil, at 2200-2300 m'. It may be Primulion intricatae, but more ecological and floristical data are needed. Specimen examined: None.

Entoloma incarnatofuscescens (Britzelm.) Noordel.

Previously published record: Vila \& al. (1997).

Collection cited: Site 7, 16 Aug 1996.

Notes on habitat: The habitat is described as 'between Dryas octopetala at 2220 m'. It may be Primulion intricatae or Oxytropido-Elynion. More ecological and floristical details are needed. Specimen examined: None.

Entoloma infula (Fr.) Noordel.

Previously published record: None.

Specimen examined: Not preserved, site 21, 30 Aug 2002, Arabidion caeruleae, leg. \& det. G. Corriol. - Not preserved, site 24, 2 sep 2002, Salicion herbaceae, leg. G. Corriol and T. Le Moal, det. G. Corriol. - Not preserved, site 17, 14 Sep 2005, Arabidion caeruleae, leg. G. Corriol \& N. Lavaupot, det. G. Corriol.

Entoloma jubatum (Fr. : Fr.) P. Karst.

Previously published record: None.

Specimen examined: GC 05091412, site 17, 14 Sep 2005, Nardion, leg. G. Corriol \& N. Lavaupot, det. G. Corriol.

Entoloma lanicum (Romagn.) Noordel.

Previously published record: Vila \& Esteve-Raventós (1998).

Collection cited: Sirte 7, 12 Aug 1997 and 27 Aug 1997.

Notes on habitat: The habitat is described as 'between Dryas octopetala and Salix retusa at 2220 m'. It may be Arabidion caeruleae or Oxytropido-Elynion. More ecological and floristical details are needed.

Specimen examined: None.

Entoloma occultopigmentatum Arnolds \& Noordel.

Previously published record: Esteve-Raventós \& al. (1997).

Collection cited: Site 1, 18 Jul 1996.

Notes on habitat: The habitat is described as 'in nitrificate pasture land on acidic soil at 2300 m'. More floristical and ecological information are needed to state the type of habitat.

Specimen examined: None.

Entoloma papillatum (Bres.) Dennis

Previously published record: Vila \& al. (2001).

Collection cited: Site 7, 10 Aug 1999.

Notes on habitat: The habitat is described as 'between Dryas octopetala and Salix retusa at 2220 m'. It may be Arabidion caeruleae or Oxytropido-Elynion. More ecological and floristical details are needed.

Specimen examined: None. 
Entoloma poliopus (Romagn.) Noordel. var. poliopus

Previously published record: Esteve-Raventós \& al. (1997).

Collection cited: Site 5, 14 Aug 1996.

Notes on habitat: The habitat is described as 'in alpine pasture land on basic soil at 2200-2300

m'. It may be Primulion intricatae, but more ecological and floristical data are needed.

Specimen examined: None.

Entoloma poliopus var. alpigenum (J. Favre) M. Bon

Previously published record: Bon \& Ballarà (1996).

Collection cited: Site 35, 8 Jul 1995.

Notes on habitat: The habitat is described as 'among Salix retusa at 2300 m'. It is probably Arabidion caeruleae.

Previously published record: Vila \& al. (1997).

Collection cited: Site 7, 16 Aug 1997.

Notes on habitat: The habitat is described as 'between Dryas octopetala at 2220 m'. It may be connected to Primulion intricatae or Oxytropido-Elynion. More ecological and floristical details are necessary.

Specimen examined: Not preserved, site 21, 30 Aug 2002, Arabidion caeruleae, leg. \& det. G. Corriol. - Not preserved, site 19, 14 Sep 2005, Arabidion caeruleae, leg. G. Corriol \& N. Lavaupot, det. G. Corriol. - GC 05091431, site 17, 14 Sep 2005, Arabidion caeruleae, leg. G. Corriol \& N. Lavaupot, det. G. Corriol. - GC 06081605, site 16, 16 Aug 2006, Arabidion caeruleae, leg. G. Corriol, C. Hannoire and E. Trouillard, det. G. Corriol.

Entoloma poliopus var. discolor Noordel.

Previously published record: None. G. Corriol.

Specimen examined: GC 03090203, site 24, 2 Sep 2003, Salicion herbaceae, leg. G. Corriol and T. Le Moal, det.

Entoloma politoflavipes Noordel. \& Liiv

Previously published record: Vila \& al. (2001).

Collection cited: Site 7, 10 Aug 1999.

Notes on habitat: The habitat is described as 'between Dryas octopetala and Salix retusa at 2220 m'. It may be Arabidion caeruleae or Oxytropido-Elynion. More ecological and floristical details are necessary.

Specimen examined: None.

Entoloma prunuloides (Fr. : Fr.) Quél.

Previously published record: Esteve-Raventós \& al. (1997).

Collection cited: Site 5, 14 Aug 1996.

Notes on habitat: The habitat is described as 'in alpine pasture land on calcareous substrate, at 2200-2300 m'. It may be Primulion intricatae, but more ecological and floristical data are needed. Specimen examined: Not preserved, site 17, 10 Sep 2003, Arabidion caeruleae, leg. \& det. G. Corriol. - GC 05091425, site 17, 14 Sep 2005, Arabidion caeruleae, leg. G. Corriol \& N. Lavaupot, det. G. Corriol.

Entoloma pseudoturci Noordel.

Previously published record: None.

Specimen examined: Not preserved, site 24, 25 Aug 2004, Arabidion caeruleae, leg. G. Corriol, T. Le Moal, P. Burr $\&$ N. Lavaupot, det. G. Corriol. 


\section{Entoloma rhombisporum var. floccipes Noordel.}

Previously published record: None.

Specimen examined: GC 05091436, site 17, 14 Sep 2005, Arabidion caeruleae, leg. G. Corriol \& N. Lavaupot, det. G. Corriol.

Entoloma rusticoides (Gillet) Noordel.

Previously published record: None.

Specimen examined: GC 04091004, site 19, 10 Sep 2004, Arabidion caeruleae, leg. \& det. G. Corriol.

Entoloma scabropellis Noordel.

Previously published record: Vila \& Esteve-Raventós (1998).

Collection cited: Site 7, 27 Aug 1997.

Notes on habitat: The habitat is described as 'between Dryas octopetala and Salix retusa at $2300 \mathrm{~m}$ '. It may be Arabidion caeruleae or Oxytropido-Elynion. More ecological and floristical details are necessary.

Specimen examined: None.

Entoloma sericellum (Fr. : Fr.) P. Kumm.

Previously published record: Ballarà (1997).

Collection cited: Site 8, 13 Aug 1996.

Notes on habitat: The habitat is described as 'among Salix reticulata, 2300-2400 m'. It is probably Arabidion caeruleae.

Previously published record: Vila \& al. (1998).

Collection cited: Site 7, 12 Aug 1997 and 27 Aug 1997.

Notes on habitat: The habitat is described as 'between Dryas octopetala and mosses at 2300 m'. It may be Primulion intricatae, Oxytropido-Elynion or Arctostaphylo-Cetrarion. More ecological and floristical data are necessary.

Specimen examined: Not preserved, site 20, 23 Aug 2003, Arabidion caeruleae, leg. \& det. G. Corriol. - GC 05091424, site 17, 14 Sep 2005, Arabidion caeruleae, leg. G. Corriol \& N. Lavaupot, det. G. Corriol. - Not preserved, site 16, 16 Aug 2006, Arabidion caeruleae, leg. G. Corriol, C. Hannoire and E. Trouillard, det. G. Corriol. - Not preserved, site 22, 9 Sep 2006, Salicion herbaceae, leg. \& det. G. Corriol.

Entoloma sericeum (Bull.) Quél. var. sericeum

Previously published record: Ballarà (1997).

Collection cited: Site 34, 26 Aug 1995.

Notes on habitat: The habitat is described as 'among Salix herbacea at 2350 m'. It is probably Salicion herbaceae.

Previously published record: Esteve-Raventós \& al. (1997).

Collection cited: Site 5, 14 Aug 1996.

Notes on habitat: The habitat is described as 'in alpine pasture land on calcareous substrate at 2200-2300 m'. It may be Primulion intricatae, but more ecological and floristical data are needed.

Previously published record: Vila \& al. (2001).

Collection cited: Site 4, 28 Sep 1999.

Notes on habitat: The habitat is described as 'between Salix reticulata and S. herbacea at 2210 m'. It is probably Arabidion caeruleae.

Specimen examined: Not preserved, site 16, 28 Aug 2003, Arabidion caeruleae, leg. \& det. G. Corriol. - Not preserved, site 20, 23 Aug 2003, Arabidion caeruleae, leg. \& det. G. Corriol. 


\section{Entoloma sericeum var. cinereopacum Noordel.}

Previously published record: Vila \& al. (1997).

Collection cited: Site 7, 16 Aug 1996.

Notes on habitat: The habitat is described as 'between Salix retusa and Dryas octopetala at 2220 m'. It may be Arabidion caeruleae or Oxytropido-Elynion. More ecological and floristical details are necessary. G. Corriol.

Specimen examined: GC 05091447, site 17, 14 Sep 2005, Arabidion caeruleae, leg. G. Corriol \& N. Lavaupot, det.

\section{Entoloma sericeum f. nanum (J. Favre) Horak}

Previously published record: Vila \& al. (1998).

Collection cited: Site 12, 14 Aug 1997.

Notes on habitat: The habitat is described as 'between Salix herbacea at 2350 m'. It certainly is a snow bed of the Salicetea herbaceae class, but without more floristical or stational information, we cannot choose between the Salicion herbaceae or Arabidion caeruleae alliances.

Specimen examined: None.

Entoloma sericeum f. nolaniforme (Kühner) Noordel.

Previously published record: Ballarà (1997).

Collection cited: Site 3, 24 Aug 1996.

Notes on habitat: The habitat is described as 'among Dryas octopetala, 2300-2350 m'. It may be Primulion intricatae, Oxytropido-Elynion or Arctostaphylo-Cetrarion. More ecological and floristical data are necessary.

Specimen examined: GC 06081607, site 16, 16 Aug 2006, Arabidion caeruleae, leg. G. Corriol, C. Hannoire and E. Trouillard, det. G. Corriol.

\section{Entoloma serrulatum (Fr. : Fr.) Hesler}

Previously published record: Esteve-Raventós \& al. (1997).

Collection cited: Site 5, 14 Aug 1996.

Notes on habitat: The habitat is described as 'in alpine pasture land on calcareous substrate at 2200-2300 m'. It may be Primulion intricatae, but more ecological and floristical data are needed.

Previously published record: Vila \& al. (1997).

Collection cited: Site 7, 16 Aug 1996.

Notes on habitat: The habitat is described as 'between Dryas octopetala at 2220 m'. It may be Primulion intricatae, Oxytropido-Elynion or Arctostaphylo-Cetrarion. More ecological and floristical data are necessary.

Specimen examined: Not preserved, site 21, 30 Aug 2002, Arabidion caeruleae, leg. \& det. G. Corriol. - Not preserved, site 24, 2 Sep 2003, Salicion herbaceae, leg. G. Corriol and T. Le Moal, det. G. Corriol. - Not preserved, site 17, 10 Sep 2003, Arabidion caeruleae, leg. \& det. G. Corriol. - Not preserved, site 24, 25 Aug 2004, Arabidion caeruleae, leg. G. Corriol, T. Le Moal, P. Burr \& N. Lavaupot, det. G. Corriol.

Entoloma turci (Bres.) M.M. Moser

Previously published record: Esteve-Raventós \& al. (1997).

Collection cited: Site 5, 27 Aug 1996.

Notes on habitat: The habitat is described as 'in alpine pasture land on calcareous substrate at 2200-2300 m'. It may be Primulion intricatae, but more ecological and floristical data are needed. Specimen examined: Not preserved, site 24, 2 Sep 2003, Salicion herbaceae, leg. G. Corriol and T. Le Moal, det. G. 
Corriol. - GC 05091409, site 17, 14 Sep 2005, Arabidion caeruleae, leg. G. Corriol \& N. Lavaupot, det. G. Corriol.

Entoloma undatum (Fr. $\rightarrow$ Gillet) M.M. Moser

Previously published record: Ballarà (1997).

Collection cited: Site 8, 18 Aug 1996.

Notes on habitat: The habitat is described as 'among mosses, close to Salix reticulata, 2300-2400 m'. It is probably Arabidion caeruleae.

Previously published record: Vila \& al. (2001).

Collection cited: Site 7, 10 Aug 1999.

Notes on habitat: The habitat is described as 'between Dryas octopetala, mosses and Salix retusa at 2220 m'. It may be Arabidion caeruleae or Oxytropido-Elynion. More ecological and floristical details are necessary.

Specimen examined: None.

Galerina annulata (J. Favre) Singer

Previously published record: None.

Specimen examined: GC 06083107, site 13, Montagne de Cap de Long, altitude 2575 m, 31 Aug 2006, CardaminoMontenion with Salix herbacea, leg. \& det. G. Corriol.

Galerina pseudocerina A.H. Sm. \& Singer

Previously published record: Ballarà (1997).

Collection cited: Site 35, 13 Jul 1996.

Taxonomic notes: According to Bon (1992) and Gulden (1992), our collection is affine to $G$. pseudocerina, but has smaller spores $(8-11 \times 5,5-7,5 \mu \mathrm{m})$, which makes it intermediate toward $G$. mairei Boutev. \& P.-A. Moreau, a typical peat-bog species.

Notes on habitat: Ballarà described the habitat as 'among mosses, close to Salix retusa at 2300 m'. It is probably Arabidion caeruleae.

Specimen examined: GC 03082803, site 16, 28 Aug 2003, Arabidion caeruleae, leg. \& det. G. Corriol.

\section{Galerina pseudotundrae Kühner}

Previously published record: Bon \& Ballarà (1997).

Collection cited: Site 25, 12 Sep 1993.

Notes on habitat: The habitat is described as 'with Salix herbacea at 2700 m'. It is probably

Salicion herbaceae.

Specimen examined: None.

Galerina rubiginosa (Fr.) Kühner ss. stricto Kühner

Previously published record: None.

Specimen examined: Not preserved, site 24, 2 Sep 2003, Salicion herbaceae, leg. G. Corriol and T. Le Moal, det. G. Corriol. - GC 06083105, site 13, Montagne de Cap de Long, altitude 2575 m, 31 Aug 2006, Eriophorion scheuchzeri, leg. \& det. G. Corriol.

Hebeloma alpinum (J. Favre) Bruchet

Previously published record: Ballarà (1997).

Collection cited: Site 3, 27 Jul 1995 and 27 Jul 1996.

Notes on habitat: The habitat is described as 'on Dryas octopetala, 2300-2350 m'. It may be 
Primulion intricatae, Oxytropido-Elynion or Arctostaphylo-Cetrarion. More ecological and floristical data are necessary.

Previously published record: Vila \& al. (1998).

Collection cited: Site 7, 27 Aug 1997.

Notes on habitat: The habitat is described as 'between Dryas octopetala and Salix retusa at 2220 m'. It may be Arabidion caeruleae or Oxytropido-Elynion. More ecological and floristical details are necessary.

Other unpublished record: NdM 03091902/2249-5, site 30, 19 Sep 2003, Oxytropido-Elynion, leg. \& det. N. de Munnik.

Specimen examined: Not preserved, site 21, 30 Aug 2002, Arabidion caeruleae with Salix retusa, leg. \& det. G. Corriol. - Not preserved, site 19, 14 Sep 2005, Arabidion caeruleae, leg. G. Corriol \& N. Lavaupot, det. G. Corriol. - GC 05091406, site 17, 14 Sep 2005, Arabidion caeruleae, leg. G. Corriol \& N. Lavaupot, det. G. Corriol.

\section{Hebeloma bruchetii Bon}

Previously published record: Esteve-Raventós \& al. (1997).

Collection cited: Site 5, 14 Aug 1996 and 27 Aug 1996.

Notes on habitat: The habitat is described as 'in soil, with Salix pyrenaica at 2200 m'. It may be Primulion intricatae, but more ecological and floristical data are needed.

Previously published record: Vila \& al. (1997).

Collection cited: Site 11, 12 Sep 1996.

Notes on habitat: The habitat is described as 'between Salix pyrenaica at 2150 m'. This is very likely a subalpine instead of an alpine collection, according to the relatively low altitude and ectomycorhizal host, Salix pyrenaica which is characteristic from the subalpine basophilous, psychrophilous grasslands of the Primulion intricatae. However, we quote it because $H$. bruchetii is a true alpine species (Bruchet, 1970 as H. repandum) and does exist in the alpine stage of the Pyrenees too. It is noteworthy that this alpine Hebeloma can be associated to the Pyrenean endemic willow $S$. pyrenaica instead of its usual alpine host, S. herbacea.

Specimen examined: NdM 97100202/2048-9, site 32, 2 Oct 1997, Arabidion caeruleae with Salix reticulata and Dryas octopetala, leg. N. de Munnik, det. G. Corriol. - GC 06083104, site 13, Montagne de Cap de Long, altitude 2575 m, 31 Aug 2006, Eriophorion scheuchzeri, leg. \& det. G. Corriol.

Hebeloma edurum Métrod ex Bon

Previously published record: Vila \& al. (1998).

Collection cited: Site 7, 27 Aug 1997.

Notes on habitat: The habitat is described as 'between Dryas octopetala and Salix retusa at 2300 m'. It may be Arabidion caeruleae or Oxytropido-Elynion. More ecological and floristical details are necessary.

Specimen examined: None.

Hebeloma marginatulum (J. Favre) Bruchet

Previously published record: Ballarà (1997).

Collection cited: Site 2, 8 Oct 1994, 9 Oct 1994 and 10 Jul 1995.

Notes on habitat: The habitat is described as 'among Salix retusa and S. reticulata, 2300-2350

m'. It is probably Arabidion caeruleae, but more ecological and floristical data are needed.

Previously published record: Ballarà (1997) under « f. flammuloides Ballarà prov. ».

Collection cited: Site 2, 19 Sep 1994.

Notes on habitat: The habitat is described as 'among Salix retusa and S. pyrenaica, 2300-2350 m'. It is probably Arabidion caeruleae. 
Previously published record: Esteve-Raventós \& al. (1997).

Collection cited: Site 1, 31 Aug 1996.

Notes on habitat: The habitat is described as 'in Salix herbacea carpet, on acidic soil, at 2400 m'. It is probably Salicion herbaceae.

Previously published record: Vila \& al. (1998).

Collection cited: Site 7, 27 Aug 1997.

Notes on habitat: The habitat is described as 'between Dryas octopetala and Salix retusa at 2220 m'. It may be Arabidion caeruleae or Oxytropido-Elynion. More ecological and floristical details are necessary.

Previously published record: Vila \& al. (2001).

Collection cited: Site 4, 28 Sep 1999.

Notes on habitat: The habitat is described as 'between Salix herbacea at 2210 m'. It certainly is a snow bed of the Salicetea herbaceae class, but without more floristical or stational information, we cannot choose between the Salicion herbaceae or Arabidion caeruleae alliances.

Specimen examined: Not preserved, site 31, 30 Aug 2002, Arabidion caeruleae, with Salix retusa, leg. \& det. G. Corriol. - Not preserved, site 17, 10 Sep 2003, Arabidion caeruleae, leg. \& det. G. Corriol. - GC 04091905, site 22, 19 Sep 2004, Salicion herbaceae, leg. \& det. G. Corriol. - GC 06081611, site 16, 16 Aug 2006, Arabidion caeruleae, leg. G. Corriol, C. Hannoire and E. Trouillard, det. G. Corriol. - Not preserved, site 22, 9 Sep 2006, Salicion herbaceae, leg. \& det. G. Corriol.

Hebeloma mesophaeum (Pers.) Quél.

Previously published record: Vila \& al. (1998).

Collection cited: Site 7, 27 Aug 1997.

Notes on habitat: The habitat is described as 'between Dryas octopetala and Salix retusa at 2300 m'. It may be Arabidion caeruleae or Oxytropido-Elynion. More ecological and floristical details are necessary.

Specimen examined: Not preserved, site 18, 3 Sep 2003, Salicion herbaceae, leg. \& det. G. Corriol. - GC 04091903 , site 22, 19 Sep 2004, Salicion herbaceae, leg. \& det. G. Corriol. - GC 05091439, site 19, 14 Sep 2005, Arabidion caeruleae, leg. G. Corriol \& N. Lavaupot, det. G. Corriol.

Hebeloma theobrominum Quadr. (f. chamaesalicis M. Bon prov.)

Previously published record: None.

Taxonomic note: This taxon is characterized by small spores $(8-10 \times 4,5-5 \mu \mathrm{m}$ in our collection), lageni-clavate to cylindro-clavate cystidia, amygdaliform spores, cacao-raphanoid smell. We could find some micro-drops on the lamellae. It could be the same alpine form as noticed by Bon (2002).

Specimen examined: GC 05091426, site 17, 14 Sep 2005, Arabidion caeruleae, leg. G. Corriol \& N. Lavaupot, det. G. Corriol.

Hebeloma versipelle (Fr.) Gillet ss. Bon (cf. var. citerinii M. Bon prov.)

Previously published record: None.

Taxonomic note: These collections, in the section Indusiata are characterised by small spores, not discolor cap, with poorly developped veil, and blackening stem. They match the alpine form of H. versipelle as given by Citerin (1993) and Bon (2002).

Specimen examined: GC 05091441, site 19, 14 Sep 2005, Arabidion caeruleae, leg. G. Corriol \& N. Lavaupot, det. G. Corriol. - GC 05091435, site 17, 14 Sep 2005, Arabidion caeruleae, leg. G. Corriol \& N. Lavaupot, det. G. Corriol.

\section{Hydropus scabripes var. quadrisporus Bas}

Previously published record: Vila \& al. (2001). 
Collection cited: Site 12, 29 Aug 1998.

Notes on habitat: The habitat is described as 'between Salix retusa and grasses at 2300 m'. It is probably Arabidion caeruleae. G. Corriol.

Specimen examined: GC 05091410, site 17, 14 Sep 2005, Arabidion caeruleae, leg. G. Corriol \& N. Lavaupot, det.

Hygrocybe calciphila Arnolds

Previously published record: Bon \& Ballarà (1996).

Collection cited: Site 35, 8 Jul 1995.

Notes on habitat: The habitat is described as 'among Salix retusa at 2300 m'. It is probably Arabidion caeruleae.

Previously published record: Vila \& al. (1998).

Collection cited: Site 7, 27 Aug 1997.

Notes on habitat: The habitat is described as 'between Dryas octopetala at 2220 m'. It may be Primulion intricatae, Oxytropido-Elynion or Arctostaphylo-Cetrarion. More ecological and floristical data are necessary.

Specimen examined: None.

Hygrocybe cereacea (Fr. : Fr.) P. Kumm.

Previously published record: None.

Specimen examined: Not preserved, site 16, 16 Aug 2006, Arabidion caeruleae, leg. G. Corriol, C. Hannoire and E. Trouillard, det. G. Corriol.

Hygrocybe cereopallida (Clémençon) comb. ined. = Camarophyllus cereopallidus Clémençon

Previously published record: None.

Specimen examined: Not preserved, site 19, 14 Sep 2005, Arabidion caeruleae, leg. G. Corriol \& N. Lavaupot, det. G. Corriol. - Not preserved, site 17, 14 Sep 2005, Arabidion caeruleae, leg. G. Corriol \& N. Lavaupot, det. G. Corriol. - Not preserved, site 16, 16 Aug 2006, Arabidion caeruleae, leg. G. Corriol, C. Hannoire and E. Trouillard, det. G. Corriol.

Hygrocybe coccinea (Schaeff. : Fr.) P. Kumm.

Previously published record: Vila \& al. (2001).

Collection cited: Site 3, 22 Aug 1999.

Notes on habitat: The habitat is described as 'between Dryas octopetala and Salix reticulata at 2240 m'. It may be Arabidion caeruleae or Oxytropido-Elynion. More ecological and floristical details are necessary.

Other unpublished record: Not preserved, site 32, 2 Oct 1997, Arabidion caeruleae with Salix reticulata and Dryas octopetala, leg. \& det. N. de Munnik. G. Corriol.

Specimen examined: Not preserved, site 17, 14 Sep 2005, Arabidion caeruleae, leg. G. Corriol \& N. Lavaupot, det.

Hygrocybe colemanniana (A. Bloxam) P.D. Orton \& Watling

Previously published record: Vila \& al. (2001).

Collection cited: Site 4, 28 Sep 1999.

Notes on habitat: The habitat is described as 'between Salix herbacea at 2210 m'. It certainly is a snow bed of the Salicetea herbaceae class, but without more floristical or stational information, we cannot choose between the Salicion herbaceae or Arabidion caeruleae alliances. 
Specimen examined: Not preserved, site 19, 14 Sep 2005, Arabidion caeruleae, leg. G. Corriol \& N. Lavaupot, det. G. Corriol. - Not preserved, site 17, 14 Sep 2005, Arabidion caeruleae, leg. G. Corriol \& N. Lavaupot, det. G. Corriol.

Hygrocybe conica (Schaeff. : Fr.) P. Kumm. ss. lato

Previously published record: Vila \& al. (1998).

Collection cited: Site 7, 12 Aug 1997 and 27 Aug 1997.

Notes on habitat: The habitat is described as 'between Dryas octopetala at $2300 \mathrm{~m}$ ' and 'between Dryas octopetala and Salix retusa at 2300 m'. It may be Primulion intricatae, OxytropidoElynion or Arctostaphylo-Cetrarion and Arabidion caeruleae or Oxytropido-Elynion. More ecological and floristical data are necessary.

Previously published record: Vila \& al. (2001).

Collection cited: Site 4, 28 Sep 1999.

Notes on habitat: The habitat is described as 'between Salix herbacea and Rhododendron ferrugineum at $2210 \mathrm{~m}$ '. It is probably Salicion herbaceae.

Specimen examined: None.

Hygrocybe conica (Schaeff.: Fr.) P. Kumm. var. conica ss. stricto

Previously published record: Esteve-Raventós \& al. (1997).

Collection cited: Site 5, 14 Aug 1996.

Notes on habitat: The habitat is described as 'in alpine pasture land on basic soil at $2250 \mathrm{~m}$ '. It may be Primulion intricatae, but more ecological and floristical data are needed.

G. Corriol.

Specimen examined: GC 05091427, site 17, 14 Sep 2005, Arabidion caeruleae, leg. G. Corriol \& N. Lavaupot, det.

Hygrocybe fornicata var. streptopus (Fr.) Arnolds

Previously published record: None.

G. Corriol

Specimen examined: GC 05091411, site 17, 14 Sep 2005, Arabidion caeruleae, leg. G. Corriol \& N. Lavaupot, det.

Hygrocybe fuscescens (Bres.) P.D. Orton \& Watling

Previously published record: GC 05091437, site 17, 14 Sep 2005, Arabidion caeruleae, leg. G. Corriol \& N. Lavaupot, det. G. Corriol.

Specimen examined: None.

Hygrocybe glacialis T. Borgen \& Senn-Irlet

Previously published record: Vila \& al. (1998).

Collection cited: Site 7, 27 Aug 1997.

Notes on habitat: The habitat is described as 'between mosses at 2220 m'. One can't conclude on the habitat. More ecological and floristical details are needed.

Specimen examined: None.

Hygrocybe hygrocyboides (Kühner) Arnolds

Previously published record: None.

Notes on distribution: Our collection of this singular species matches well the description of Kühner (1977) from one French and one Swiss collection from the Alps.

The only other citation in bibliography seems to be an italian alpian collection (Candusso 1997). 
Its discovery in arctic area is very recent (personnal communication, T. Borgen), from Greenland and Sweeden.

Specimen examined: GC 04092702, site 16, 27 Sep 2004, Arabidion caeruleae, leg. \& det. G. Corriol.

Hygrocybe persistens (Britzelm.) Singer var. persistens

Previously published record: Ballarà (1997).

Collection cited: Site 2, 20 Aug 1995.

Notes on habitat: The habitat is described as 'in alpine grassland, close to Salix retusa, 2300-2350 m'. It is probably Arabidion caeruleae.

Previously published record: Esteve-Raventós \& al. (1997).

Collection cited: Site 5, 14 Aug 1996.

Notes on habitat: The habitat is described as 'in alpine pasture land on basic substrate at 2250 m'. It may be Primulion intricatae, but more ecological and floristical data are needed.

Previously published record: Vila \& al. (2001).

Collection cited: Site 4, 23 Jul 1999.

Notes on habitat: The habitat is described as 'between Dryas octopetala at 2220 m'. It may be Primulion intricatae, Oxytropido-Elynion or Arctostaphylo-Cetrarion. More ecological and floristical data are necessary.

Other unpublished record: Not preserved, site 32, 2 Oct 1997, Arabidion caeruleae with Salix reticulata and Dryas octopetala, leg. \& det. N. de Munnik.

Specimen examined: None.

Hygrocybe pratensis (Pers. : Fr.) Murril

Previously published record: Bon \& Ballarà (1996), Vila \& al. (2001).

Collection cited: Site 34, 26 Aug 1995. - Site 4, 28 Sep 1999.

Notes on habitat: The habitat is described as 'among Salix herbacea at $2350 \mathrm{~m}$ ' and 'between

Salix herbacea at 2210 m'. It certainly is a snow bed of the Salicetea herbaceae class, but without more floristical or stational information, we cannot choose between the Salicion herbaceae or Arabidion caeruleae alliances.

Specimen examined: Not preserved, site 20, 23 Aug 2003, Arabidion caeruleae, leg. \& det. G. Corriol.

Hygrocybe pseudoconica J.E. Lange var. pseudoconica

Previously published record: None.

Specimen examined: Not preserved, site 19, 10 Sep 2004, Arabidion caeruleae, leg. \& det. G. Corriol.

Hygrocybe pseudoconica var. tristis (Pers.) Bon

Previously published record: Bon \& Ballarà (1996).

Collection cited: Site 35, 20 Aug 1995.

Notes on habitat: The habitat is described as 'among Salix retusa at 2300 m'. it is probably Arabidion caeruleae.

Specimen examined: Not preserved, site 16, 28 Aug 2003, Arabidion caeruleae, leg. \& det. G. Corriol. - Not preserved, site 24, 2 Sep 2003, Salicion herbaceae, leg. G. Corriol and T. Le Moal, det. G. Corriol. - Not preserved, site 17, 10 Sep 2003, Arabidion caeruleae, leg. \& det. G. Corriol. Not preserved, site 20, 23 Aug 2003, Arabidion caeruleae, leg. \& det. G. Corriol. - Not preserved, site 16, 16 Aug 2006, Arabidion caeruleae, leg. G. Corriol, C. Hannoire and E. Trouillard, det. G. Corriol.

Hygrocybe psittacina (Schaeff.: Fr.) P. Kumm.

Previously published record: Esteve-Raventós \& al. (1997). 
Collection cited: Site 5, 14 Aug 1996.

Notes on habitat: The habitat is described as 'in alpine pasture land at 2250'. More ecological and floristical data are needed to state the type of habitat G. Corriol.

Specimen examined: Not preserved, site 17, 14 Sep 2005, Arabidion caeruleae, leg. G. Corriol \& N. Lavaupot, det.

Hygrocybe quieta (Kühner) Singer

Previously published record: None. Corriol.

Specimen examined: GC 05091433, site 17, 14 Sep 2005, Nardion strictae, leg. G. Corriol \& N. Lavaupot, det. G.

Hygrocybe reae (R. Maire) J.E. Lange

Previously published record: None.

Specimen examined: GC 05091430, site 17, 14 Sep 2005, Arabidion caeruleae, site 17, 14 Sep 2005.

Hygrocybe salicis-herbaceae Kühner

Previously published record: Vila \& al. (1998).

Collection cited: Site 7, 27 Aug 1997.

Notes on habitat: The habitat is described as 'between Salix herbacea at 2400 m'. It certainly is a snow bed of the Salicetea herbaceae class, but without more floristical or stational information, we cannot choose between the Salicion herbaceae or Arabidion caeruleae alliances.

Specimen examined: None.

Hygrocybe spadicea (Scop.: Fr.) P. Karst.

Previously published record: None.

Specimen examined: Not preserved, site 15, 17 Aug 2002, Loiseleurio-Vaccinion, leg. \& det. G. Corriol.

Hygrocybe virginea (Wulfen : Fr.) P.D. Orton \& Watling

Previously published record: Vila \& al. (1998).

Collection cited: Site 7, 27 Aug 1997.

Notes on habitat: The habitat is described as 'between Dryas octopetala and Salix retusa at 2300 m'. It may be Arabidion caeruleae or Oxytropido-Elynion. More ecological and floristical details are needed..

Previously published record: Vila \& al. (2001).

Collection cited: Site 4, 28 Sep 1999.

Notes on habitat: The habitat is described as 'between Salix herbacea at 2210 m'. It certainly is a snow bed of the Salicetea herbaceae class, but without more floristical or stational information, we cannot choose between the Salicion herbaceae or Arabidion caeruleae alliances.

Other unpublished reccords: NdM 97100203/2048-9, site 32, 2 Oct 1997, Arabidion caeruleae with Salix reticulata and Dryas octopetala, leg. \& det. N. de Munnik. - Not preserved, site 29, 3 Sep 2002, Nardion strictae, leg. \& det. N. de Munnik.

Specimen examined: Not preserved, site 16, 28 Aug 2003, Arabidion caeruleae, leg. \& det. G. Corriol. - Not preserved, site 17, 10 Sep 2003, Arabidion caeruleae, leg. \& det. G. Corriol. - Not preserved, site 17, 14 Sep 2005, Arabidion caeruleae, leg. G. Corriol \& N. Lavaupot, det. G. Corriol. - Not preserved, site 16, 16 Aug 2006, Arabidion caeruleae, leg. G. Corriol, C. Hannoire and E. Trouillard, det. G. Corriol. 
Inocybe agardhii (N. Lund) P.D. Orton (f. calcicola Bon \& Ballarà prov.)

Previously published record: Bon \& Ballarà (1996).

Collection cited: Site 2, 8 Jul 1995.

Notes on habitat: The habitat is described as 'with Salix reticulata and S. retusa at 2150 m'. It is probably Arabidion caeruleae.

Specimen examined: None.

Inocybe aff. albidodisca var. reidii Stangl \& J. Veselský

Previously published record: None.

Taxonomic notes: Our collection matches well this variety of I. albidodisca with some spores streched up to $18 \mu \mathrm{m}$. The other characters are those of I. albidodisca: the color and veil of the cap, the witish entirely pruinose stem and cystidia with wide wall (up to $\mathrm{x} 4 \mu \mathrm{m}$ ), not coloured in $\mathrm{NH}_{3}$ solution; except the odor which is Pelargonium like, a character which could bring it near I. subpaleacea Kühner. This last species has a different macroscopical aspect (darker cap color and velvety veil). Specimen examined: GC 03091013, site 17, 10 Sep 2003, Arabidion caeruleae, leg. \& det. G. Corriol.

Inocybe alboperonata Kühner

Previously published record: Esteve-Raventós \& Vila (1998).

Collections cited: Site 7, 12 Aug 1996 and 27 Aug 1997.

Notes on habitat: The habitat is described as 'between Dryas octopetala and Loiseleuria procumbens at $2220 \mathrm{~m}$ ' and 'between Dryas octopetala and Salix retusa at $2220 \mathrm{~m}$ and at 2300m'. For the first collection, it may be Arctostaphylo-Cetrarion. For the second collection, it may be Arabidion caeruleae or Oxytropido-Elynion. More ecological and floristical details are needed.

Specimen examined: None.

Inocybe arthrocystis Kühner

Previously published record: None.

Specimen examined: GC 03082805, site 16, 28 Aug 2003, Arabidion caeruleae, leg. \& det. G. Corriol.

Inocybe asterospora Quél.

Previously published record: None.

Specimens examined: Not preserved, site 17, 10 Sep 2004, Arabidion caeruleae, leg. \& det. G. Corriol. - GC 04091912, site 22, 19 Sep 2004, Salicion herbaceae, leg. \& det. G. Corriol.

Inocybe bivela Kühner

Previously published record: Vila \& al. (2001).

Collection cited: Site 7, 10 Aug 1999.

Notes on habitat: The habitat is described as 'between Dryas octopetala and Salix retusa at 2220 m'. It may be Arabidion caeruleae or Oxytropido-Elynion. More ecological and floristical details are needed.

Specimen examined: None.

Inocybe calamistrata (Fr. : Fr.) Gillet

Previously published record: Vila \& al. (2001).

Collection cited: Site 7, 10 Aug 1999. 
Notes on habitat: The habitat is described as 'between Dryas octopetala and Salix retusa at 2220 m'. It may be Arabidion caeruleae or Oxytropido-Elynion. More ecological and floristical details are needed.

Specimens examined: GC 02083007, site 21, 30 Aug 2002, Arabidion caeruleae, leg. \& det. G. Corriol. - Not preserved, site 19, 27 Aug 2004, Arabidion caeruleae, leg. G. Corriol, P. Burr \& P. Hériveau, det. G. Corriol. - Not preserved, Troumouse circus (at the east of site 14), altitude 2300 m, 13 Aug 2006, Arabidion caeruleae, leg. \& det. G. Corriol.

Inocybe canescens J. Favre

Previously published record: Esteve-Raventós \& Vila (1997).

Collection cited: Site 7, 8 Aug 1996.

Notes on habitat: The habitat is described as 'between Dryas octopetala and Salix retusa at 2220 m'. It may be Arabidion caeruleae or Oxytropido-Elynion. More ecological and floristical details are needed.

Previously published record: Esteve-Raventós \& al. (1997).

Collection cited: Site 1, 31 Aug 1996.

Notes on habitat: The habitat is described as 'in carpets of Salix herbacea, on siliceous substrate at $2400 \mathrm{~m}$ '. It is probably Salicion herbaceae.

Specimen examined: GC 04091009, site 17, 10 Sep 2004, Arabidion caeruleae, leg. \& det. G. Corriol. - GC 06081601, site 16, 16 Aug 2006, Arabidion caeruleae, leg. G. Corriol, C. Hannoire and E. Trouillard, det. G. Corriol.

\section{Inocybe aff. concinnula f. subconcinnula Kühner}

Previously published record: None.

Taxonomic notes: Our collection matches well with the description of this taxon except for the color of the cap, which was much darker (dark brown), and the lack of yellow tints. G. Corriol.

Specimen examined: GC 03082804, site 16, 28 Aug 2003, Arabidion caeruleae, with Salix reticulata, leg. \& det.

Inocybe corydalina Quél.

Previously published record: Esteve-Raventós \& Vila (1998).

Collection cited: Site 7, 27 Aug 1996.

Notes on habitat: The habitat is described as 'between Dryas octopetala at 2220 m'. It may be Primulion intricatae, Oxytropido-Elynion or Arctostaphylo-Cetrarion. More ecological and floristical data are necessary.

Specimen examined: None.

Inocybe dulcamara (Alb. \& Schwein.) P. Kumm.

Previously published record: Vila \& al. (2001).

Collection cited: Site 7, 10 Aug 1999.

Taxonomic notes: The collection we examined could be searched near I. dulcamara f. pygmaea J. Favre, taking into account the form of its marginal cells being often pyriforme to « opuntia like » and its small size. Nevertheless, its hollow stem and small spores $(6,5-9,5 \times 4,5-6 \mu \mathrm{m})$ don't match with the original description (Favre 1955).

Notes on habitat: The habitat is described as 'between Dryas octopetala and Salix retusa at 2220 m'. It may be Arabidion caeruleae or Oxytropido-Elynion. More ecological and floristical details are needed.

Specimen examined: NdM 03091904/2249-5 (cf. f. pygmaea J. Favre), site 30, 19 Sep 2003, Oxytropido-Elynion, leg. N. de Munnik, det. G. Corriol. 
Inocybe dulcamara var. cf. homomorpha Kühner

Previously published record: Ballarà (1997).

Collection cited: Site 3, 18 Aug 1996.

Notes on habitat: The habitat is described as 'among Salix retusa and S. reticulata, 2300-2350

m'. It is probably Arabidion caeruleae.

Specimen examined: None.

Inocybe egenula J. Favre

Previously published record: None.

Taxonomic notes: In our collections, we found metuloid caulocystidia down to the extreme base of the stem, character which has been noticed by Senn-Irlet (1986) too.

Specimen examined: GC 03091010, site 17, 10 Sep 2003, Arabidion caeruleae, with Salix herbacea, leg. \& det. G. Corriol. - GC 04091007, site 17, 10 Sep 2004, Arabidion caeruleae, with Salix herbacea, leg. \& det. G. Corriol.

Inocybe fastigiata f. alpestris Heim

Previously published record: Bon \& Ballarà (1996).

Collection cited: Site 2, 16 Jul 1995.

Notes on habitat: The habitat is described as 'amond Dryas octopetala at $2150 \mathrm{~m}$ '. It may be Primulion intricatae, Oxytropido-Elynion or Arctostaphylo-Cetrarion. More ecological and floristical data are necessary.

Previously published record: Vila \& al. (2001).

Collection cited: Site 7, 23 Jul 1999 and 22 Aug 1999.

Notes on habitat: The habitat is described as 'between Dryas octopetala and Salix retusa at 2220 and 2240 m'. It may be Arabidion caeruleae or Oxytropido-Elynion. More ecological and floristical details are needed.

Specimen examined: None.

Inocybe flavella P. Karst.

Previously published record: Esteve-Raventós \& Vila (1998).

Collection cited: Site 12, 14 Aug 1997.

Notes on habitat: The habitat is described as 'between Salix herbacea at 2350 m'. It is probably a snow-bed community from Salicetea herbaceae, but without more floristical or stational information, we cannot choose between the Salicion herbaceae or Arabidion caeruleae alliances.

Specimen examined: None.

Inocybe friesii Heim (f. minor J. Favre prov.)

Previously published record: None.

Specimens examined: GC 04091022, site 19, 10 Sep 2004, Arabidion caeruleae, leg. \& det. G. Corriol. - GC 05091444 , site 19, 14 Sep 2005, Arabidion caeruleae, leg. G. Corriol \& N. Lavaupot, det. G. Corriol.

Inocybe geraniodora J. Favre var. geraniodora

Previously published record: Esteve-Raventós \& al. (1997).

Collection cited: Site 5, 27 Aug 1996.

Notes on habitat: The habitat is described as 'in humus, linked to Salix reticulata in basic soil at 2300 m'. It is probably Arabidion caeruleae.

Specimen examined: None. 
Inocybe geraniodora var. depauperata J. Favre

Previously published record: Vila \& al. (2001).

Collection cited: Site 3, 22 Aug 1999.

Notes on habitat: The habitat is described as 'on decomposing leaves of Dryas octopetala and Salix reticulata at 2240 m'. It may be Arabidion caeruleae or Oxytropido-Elynion. More ecological and floristical details are needed. Specimen examined: None.

Inocybe geraniodora var. gracilenta J. Favre

Previously published record: None.

Specimen examined: Not preserved, site 19, 10 Sep 2004, Arabidion caeruleae, leg. \& det. G. Corriol. - GC 04091010, site 17, 10 Sep 2004, Arabidion caeruleae, leg. \& det. G. Corriol.

Inocybe geraniodora f. salicis-herbaceae Bon \& Ballarà

Previously published records: Bon \& Ballarà (1995) and Bon \& Ballarà (1996).

Collections cited: Site 38, 10 Sep 1994 and site 34, 26 Aug 1995.

Notes on habitat: The habitat is described as 'in the Salici-Anthelietum between Salix herbacea at 2425 m' and 'with Salix herbacea at about 2350 m'. Both collections are from Salicion herbaceae.

Specimen examined: None.

Inocybe giacomi J. Favre ex Bon

Previously published record: Bon \& Ballarà (1997).

Collection cited: Site 34, 24 Aug 1996.

Notes on habitat: The habitat is described as 'with Salix herbacea at about 2400 m'. It is probably Salicion herbaceae.

Specimen examined: None.

Inocybe humilis (J. Favre ex Horak) Esteve-Rav. \& Vila

Previously published record: Esteve-Raventós \& Vila (1998).

Collection cited: Site 12, 14 Aug 1997.

Notes on habitat: The habitat is described as 'between Salix herbacea and S. retusa, at 2300 m'. It is probably Arabidion caeruleae.

Specimen examined: None.

Inocybe hypotheja Kühner

Previously published record: Ballarà \& Escànez (1999).

Collection cited: Site 2, 30 Aug 1997.

Notes on habitat: The habitat is described as 'between Dryas octopetala at 2300 m'. It may be Primulion intricatae, Oxytropido-Elynion or Arctostaphylo-Cetrarion. More ecological and floristical data are necessary.

Specimen examined: None.

Inocybe johannae Kühner

Previously published record: Esteve-Raventós \& Vila (1998). 
Collection cited: Site 12, 2 Aug 1997 and 14 Aug 1997.

Notes on habitat: The habitat is described as 'between Salix herbacea at $2350 \mathrm{~m}$ '. It is probably a snow-bed community from Salicetea herbaceae, but without more floristical or stational information, we cannot choose between the Salicion herbaceae or Arabidion caeruleae alliances.

Specimen examined: None.

Inocybe lacera (Fr. : Fr.) P. Kumm. var. lacera

Previously published record: Esteve-Raventós \& Vila (1998).

Collection cited: Site 12, 2 Aug 1997.

Notes on habitat: The habitat is described as 'between Salix herbacea at 2350 m'. It is probably a snow-bed community from Salicetea herbaceae, but without more floristical or stational information, we cannot choose between the Salicion herbaceae or Arabidion caeruleae alliances.

Specimen examined: None.

Inocybe lacera var. heterospora J. Favre ex Bon

Previously published records: Esteve-Raventós \& Vila (1997), Ballarà \& Escànez (1999).

Collection cited: Site 7, 16 Aug 1996. - Site 2, 30 Aug 1997.

Notes on habitat: The habitat is described as 'between Dryas octopetala at $2220 \mathrm{~m}$ ' and 'between Dryas octopetala at 2300 m'. It may be Primulion intricatae, Oxytropido-Elynion or Arctostaphylo-Cetrarion. More ecological and floristical data are necessary.

Previously published record: Esteve-Raventós \& Vila (1998).

Collection cited: Site 12, 14 Aug 1997.

Notes on habitat: The habitat is described as 'between Salix herbacea at 2350 m'. It is probably a snow-bed community from Salicetea herbaceae, but without more floristical or stational information, we cannot choose between the Salicion herbaceae or Arabidion caeruleae alliances.

Specimens examined: GC 04091908, site 22, 19 Sep 2004, Salicion herbaceae, leg. \& det. G. Corriol. - GC 06080502, site 13, Lacs verts, at north of Pic de Néouvielle, altitude 2630 m, 5 Aug 2006, Salicion herbaceae, leg. \& det. G. Corriol.

Inocybe lacera f. subsquarrosa F.H. Møller

Previously published record: Vila \& al. (2001).

Collection cited: Site 12, 7 Aug 1999.

Notes on habitat: The habitat is described as 'between Salix herbacea and S. retusa, at 2300 m'. It is probably Arabidion caeruleae.

Specimen examined: None.

Inocybe lanuginosa var. ovatocystis (Boursier \& Kühner) Stangl

Previously published record: Esteve-Raventós \& Vila (1998).

Collection cited: Site 12, 14 Aug 1997.

Notes on habitat: The habitat is described as 'between Salix herbacea at 2350 m'. It is probably a snow-bed community from Salicetea herbaceae, but without more floristical or stational information, we cannot choose between the Salicion herbaceae or Arabidion caeruleae alliances.

Specimen examined: None.

Inocybe leucoblema Kühner

Previously published record: Vila \& al. (2001).

Collection cited: Site 7, 10 Aug 1999.

Notes on habitat: The habitat is described as 'between Dryas octopetala and Salix retusa 
at 2220 m'. It may be Arabidion caeruleae or Oxytropido-Elynion. More ecological and floristical details are needed.

Specimen examined: GC 06090902, site 22, 9 Sep 2006, Salicion herbaceae, leg. \& det. G. Corriol.

Inocybe leucoloma Kühner

Previously published record: Esteve-Raventós \& al. (1997).

Collection cited: Site 5, 14 Aug 1996 and 27 Aug 1996.

Notes on habitat: The habitat is described as 'linked to Salix pyrenaica in alpine calcareous scree at $2200 \mathrm{~m}$ '. More ecological and floristical data are needed to state the type of habitat.

Specimen examined: None.

Inocybe luteipes J. Favre (f. mixtipes Esteve-Rav. \& Vila prov.)

Previously published record: Esteve-Raventós \& Vila (1998).

Collection cited: Site 7, 12 Aug 1996.

Notes on habitat: The habitat is described as 'between Dryas octopetala and Salix retusa at 2220 m’. It may be Arabidion caeruleae or Oxytropido-Elynion. More ecological and floristical details are needed.

Specimen examined: None.

Inocybe metrodii Stangl \& J. Veselský (=I. glabrescens Velen ss. Kuyper)

Previously published record: Esteve-Raventós \& Vila (1998).

Collection cited: Site 12, 14 Aug 1997.

Notes on habitat: The habitat is described as 'between Salix herbacea and S. retusa, at 2300 m'. It is probably Arabidion caeruleae.

Specimen examined: None.

Inocybe mixtilis (Britzelm.) Sacc.

Previously published records: Esteve-Raventós \& Vila (1997), Esteve-Raventós \& Vila (1998).

Collection cited: Site 7, 8 Aug 1996. - Site 7, 12 Aug 1997.

Notes on habitat: The habitat is described as 'between Dryas octopetala and Salix retusa at 2220 m'. It may be Arabidion caeruleae or Oxytropido-Elynion. More ecological and floristical details are needed.

Previously published record: Vila \& al. (1998).

Collection cited: Site 12, 2 Aug 1997.

Notes on habitat: The habitat is described as 'between Salix retusa at 2300 m'. It is probably Arabidion caeruleae.

Specimen examined: GC 06081002, Estom Soubiran, high Lutour valley (at the east of site 24), altitude $2450 \mathrm{~m}, 10$ Aug 2006, Arabidion caeruleae, leg. \& det. G. Corriol.

Inocybe monochroa J. Favre

Previously published record: Bon \& Ballarà (1997).

Collection cited: Site 3, 18 Aug 1996.

Notes on habitat: The habitat is described as 'among Dryas octopetala at $2350 \mathrm{~m}$ '. It may be Primulion intricatae, Oxytropido-Elynion or Arctostaphylo-Cetrarion. More ecological and floristical data are necessary.

Specimen examined: None. 
Inocybe pelargoniodora Kühner

Previously published record: None. Corriol.

Specimen examined: GC 02083002, site 21, 30 Aug 2002, Arabidion caeruleae, with Salix retusa, leg. \& det. G.

Inocybe piriodora (Britzelm.) Sacc.

Previously published record: Ballarà (1997).

Collection cited: Site 8, 25 Aug 1996.

Notes on habitat: The habitat is described as 'among Dryas octopetala and Vaccinium vitisideae, 2300-2400 m. It may be Arctostaphylo-Cetrarion, but more floristical and ecological data is needed.

Previously published record: Esteve-Raventós \& Vila (1998) under «f. chamaesalicis M. Bon prov. ».

Collection cited: Site 7, 12 Aug 1997.

Notes on habitat: The habitat is described as 'between Dryas octopetala at 2220 m'. It may be Primulion intricatae, Oxytropido-Elynion or Arctostaphylo-Cetrarion. More ecological and floristical data are necessary.

Specimen examined: None.

Inocybe praetervisa Quél.

Previously published record: Vila \& al. (2001).

Taxonomic notes: The published data is understood ss. lato, including I. salicis-herbaceae Kühn.) when ours is understood in a strict sense, excluding the arctic-alpine species.

Collection cited: Site 7, 23 Jul 1999.

Notes on habitat: The habitat is described as 'between Dryas octopetala and Salix retusa at 2220 m'. It may be Arabidion caeruleae or Oxytropido-Elynion. More ecological and floristical details are needed.

Specimen examined: GC 06081003, Estom Soubiran, high Lutour valley (at the east of site 24), altitude $2450 \mathrm{~m}, 10$ Aug 2006, Arabidion caeruleae, leg. \& det. G. Corriol.

Inocybe pseudohiulca f. alpigena Esteve-Rav. \& Vila

Previously published record: Esteve-Raventós \& Vila (1997).

Collection cited: Site 7, 8 Aug 1996.

Notes on habitat: The habitat is described as 'between Dryas octopetala and Salix retusa at 2220 m'. It may be Arabidion caeruleae or Oxytropido-Elynion. More ecological and floristical details are needed.

Specimen examined: Not preserved, site 21, 30 Aug 2002, Arabidion caeruleae, leg. \& det. G. Corriol.

Inocybe rennyi (Berk. \& Broome) Sacc.

Previously published record: None.

Taxonomic notes: This species has very striking spores, very variable in size and shape. In our collection, they can be stretched up to $22 \mu \mathrm{m}$ long, with entolomoid to nodulose outline, some of them being even branched. This ubiquitous species was notably reported from the arctic zone from Greenland, but seemed to be unknow up to now from the European alpine zone (Bon 1997, Ferrari 2004).

Specimen examined: GC 03091015, site 17, 10 Sep 2003, Arabidion caeruleae, leg. \& det. G. Corriol. 
Inocybe rhacodes J. Favre

Previously published record: None.

Specimen examined: Not preserved, site 21, 30 Aug 2002, Arabidion caeruleae, leg. \& det. G. Corriol.

Inocybe rufobrunnea J. Favre

Previously published record: Bon \& Ballarà (1996).

Collection cited: Site 35, 8 Jul 1995.

Notes on habitat: The habitat is described as 'among Salix retusa at 2300 m'. It is probably Arabidion caeruleae.

Specimen examined: GC 04091015, site 19, 10 Sep 2004, Arabidion caeruleae, leg. \& det. G. Corriol.

Inocybe rufofusca (J. Favre) Bon

Previously published record: None.

Specimen examined: GC 03091014, site 17, 10 Sep 2003, Arabidion caeruleae, leg. \& det. G. Corriol.

Inocybe salicis-herbaceae Kühner

Previously published record: None. Corriol.

Specimen examined: GC 04082004, site 16, 20 Aug 2004, Arabidion caeruleae, leg. G. Corriol \& P. Burr, det. G.

Inocybe solidipes Kühner

Previously published record: None.

Specimen examined: GC 04082002, site 16, 20 Aug 2004, Arabidion caeruleae, leg. \& det. G. Corriol.

Inocybe soluta Velen.

Previously published record: Vila \& al. (2001).

Collection cited: Site 12, 7 Aug 1999.

Notes on habitat: The habitat is described as 'between Salix herbacea at 2350 m'. It is probably a snow-bed community from Salicetea herbaceae, but without more floristical or stational information, we cannot choose between the Salicion herbaceae or Arabidion caeruleae alliances.

Specimen examined: None.

Inocybe squarrosoannulata Kühner

Previously published record: Esteve-Raventós \& al. (1997).

Collection cited: Site 5, 27 Aug 1996.

Notes on habitat: The habitat is described as 'under Salix pyrenaica in alpine calcareous scree at $2200 \mathrm{~m}$ '. More ecological and floristical data are needed to state the type of habitat.

Specimen examined: None.

Inocybe subbrunnea Kühner

Previously published record: Vila \& al. (2001), under I. catalaunica Singer. Collection cited: Site 7, 10 Aug 1999.

Notes on habitat: The habitat is described as 'between Dryas octopetala and Salix retusa at 2220 m'. It may be Arabidion caeruleae or Oxytropido-Elynion. More ecological and floristical 
details are needed.

Specimen examined: None.

Inocybe aff. subpiricystis Kühner

Previously published record: Bon \& Ballarà (1997).

Collection cited: Site 3, 18 Aug 1996.

Notes on habitat: The habitat is described as 'with Salix pyrenaica at 2300 m'. It may be Primulion intricatae.

Specimen examined: None.

Inocybe substraminipes Kühner

Previously published record: None.

Specimen examined: GC 04091011, site 19, 10 Sep 2004, Arabidion caeruleae, leg. \& det. G. Corriol.

Inocybe tenebricoides Kühner

Previously published record: None.

Specimens examined: GC 03091009, site 17, 10 Sep 2003, Arabidion caeruleae, leg. \& det. G. Corriol. - GC 04091910, site 22, 19 Sep 2004, Salicion herbaceae, leg. \& det. G. Corriol.

Inocybe tenerella (J. Favre) Kühner

Previously published record: Esteve-Raventós \& Vila (1998).

Collection cited: Site 7, 12 Aug 1996.

Notes on habitat: The habitat is described as 'between Dryas octopetala and Salix retusa at 2220 m'. It may be Arabidion caeruleae or Oxytropido-Elynion. More ecological and floristical details are needed.

Specimen examined: None.

Inocybe aff. tenerella (J. Favre) Kühner

Previously published record: None.

Taxonomic notes: Our collection differs from Favre's description (Favre 1955) by the darker color of the cap (dark brown) and the shape of the spores which are less obtuse, more ogival.

Specimen examined: GC 04091016, site 19, 10 Sep 2004, Arabidion caeruleae, leg. \& det. G. Corriol.

Inocybe tetragonospora Kühner (f. variispora Bon \& Ballarà prov.)

Previously published record: Bon \& Ballarà (1997).

Collection cited: Site 8, 24 Aug 1996.

Notes on habitat: The habitat is described as 'among Dryas octopetala at 2350 m'. It may be Primulion intricatae, Oxytropido-Elynion or Arctostaphylo-Cetrarion. More ecological and floristical data are necessary.

Specimen examined: None.

Laccaria affinis (Singer) Bon

Previously published record: None. Corriol.

Specimen examined: Not preserved, site 16, 20 Aug 2004, Arabidion caeruleae, leg. G. Corriol \& P. Burr, det. G. 


\section{Laccaria laccata var. pseudobicolor Bon}

Previously published record: Vila \& al. (1998).

Collection cited: Site 12, 2 Aug 1997.

Notes on habitat: The habitat is described as 'between Salix herbacea at $2350 \mathrm{~m}$ '. It is probably a snow-bed community from Salicetea herbaceae, but without more floristical or stational information, we cannot choose between the Salicion herbaceae or Arabidion caeruleae alliances.

Specimen examined: None.

\section{Laccaria montana Singer}

Previously published record: Ballarà (1997).

Collection cited: Site 34, 26 Aug 1995.

Notes on habitat: The habitat is described as 'among mosses and Salix herbacea'. It is probably Salicion herbaceae.

Previously published record: Vila \& al. (1998).

Collection cited: Site 7, 27 Aug 1997.

Notes on habitat: The habitat is described as 'between Salix herbacea at 2400 m'. It is probably a snow-bed community from Salicetea herbaceae, but without more floristical or stational information, we cannot choose between the Salicion herbaceae or Arabidion caeruleae alliances.

Specimen examined: GC 04091904, site 22, 19 Sep 2004, Salicion herbaceae, leg. \& det. G. Corriol. - GC 06081606, site 16, 16 Aug 2006, Arabidion caeruleae, leg. G. Corriol, C. Hannoire and E. Trouillard, det. G. Corriol.

\section{Laccaria pumila Fayod}

Previously published record: Ballarà (1997).

Collection cited: Site 2, 16 Jul 1995.

Notes on habitat: The habitat is described as 'under Salix pyrenaica, 2300-2350 m'. It may be Primulion intricatae or Arabidion caeruleae. More ecological and floristical data are needed .

Specimens examined: NdM 97100201/2048-9, site 32, 2 Oct 1997, Arabidion caeruleae with Salix reticulata and Dryas octopetala, leg. \& det. N. de Munnik, conf. G. Corriol. - GC 04091014, site 19, 10 Sep 2004, Arabidion caeruleae, leg. \& det. G. Corriol. - GC 05091440, site 19, 14 Sep 2005, Arabidion caeruleae, leg. G. Corriol \& N. Lavaupot, det. G. Corriol. Not preserved, site 13, Montagne de Cap de Long, altitude 2575 m, 31 Aug 2006, Salicion herbaceae, leg. \& det. G. Corriol.

Laccaria tortilis (Bolton) Cooke

Previously published record: Esteve-Raventós \& al. (1997).

Collection cited: Site 1, 31 Aug 1996.

Notes on habitat: The habitat is described as 'in humid zone with Salix herbacea carpets, on acid soil at 2400 m'. It is probably Salicion herbaceae.

Specimen examined: None.

Lactarius brunneoviolaceus M.P. Christ.

Previously published record: Vila \& al. (1998).

Collections cited: Site 12, 2 Aug 1997 and 14 Aug 1997.

Notes on habitat: The habitat is described as "between Salix retusa and Salix herbacea at 2300 m'. It is probably Arabidion caeruleae.

Specimen examined: None. 


\section{Lactarius dryadophilus Kühner}

Previously published records: Ballarà (1997), Vila \& al. (1997).

Collections cited: Site 2, 8 Sep 1996. - Site 7, 16 Aug 1996.

Notes on habitat: The habitat is described as 'among Dryas octopetala, 2300-2350 m'. It may be Primulion intricatae, Oxytropido-Elynion or Arctostaphylo-Cetrarion. More ecological and floristical data are necessary.

Specimen examined: None.

Lactarius nanus J. Favre

Previously published record: Bon \& Ballarà (1996).

Collection cited: Site 34, 1 Sep 1995.

Notes on habitat: The habitat is described as 'among Salix herbacea at 2500 m'. It is probably Salicion herbaceae.

Previously published records: Vila \& al. (2001).

Collections cited: Site 12, 7 Aug 1999, site 4, 28 Sep 1999.

Notes on habitat: The habitat is described as 'between Salix herbacea and Salix retusa at 2300 $\mathrm{m}$ ' and the same 'at $2210 \mathrm{~m}$ '. It is probably Arabidion caeruleae.

Specimen examined: None.

\section{Lactarius salicis-herbaceae Kühner}

Previously published record: Ballarà (1997).

Collection cited: Site 3, 18 Aug 1996.

Notes on habitat: The habitat is described as 'among Salix retusa, 2300-2350 m'. It is probably Arabidion caeruleae.

Previously published record: Vila \& al. (2001).

Collection cited: Site 4, 8 Sep 1999.

Notes on habitat: The habitat is described as 'between Salix herbacea at $2210 \mathrm{~m}$ '. It is probably a snow-bed community from Salicetea herbaceae, but without more floristical or stational information, we cannot choose between the Salicion herbaceae or Arabidion caeruleae alliances.

Specimen examined: None.

Lepiota alba (Bres.) Saccardo

Previously published record: None.

Unpublished data: Site 31, 15 Aug 2002, Primulion intricatae with Dryas octopetala and Salix pyrenaica, leg. \& det. N. de Munnik.

Specimen examined: Not preserved, site 21, 30 Aug 2002, Arabidion caeruleae, leg. \& det. G. Corriol. - Not preserved, site 24, 2 Sep 2003, Salicion herbaceae, leg. G. Corriol and T. Le Moal, det. G. Corriol. - Not preserved, site 17, 10 Sep 2003, Nardion strictae, leg. \& det. G. Corriol. - GC 05091423, site 17, 14 Sep 2005, Nardion strictae, leg. G. Corriol \& N. Lavaupot, det. G. Corriol. - Not preserved, site 22, 19 Sep 2004, Nardion strictae, leg. \& det. G. Corriol.

Lepiota oreadiformis Velen.

Previously published record: Vila \& al. (1997).

Collection cited: Site 7, 16 Aug 1996.

Notes on habitat: The habitat is described as 'between Dryas octopetala at 2220 m'. It may be Primulion intricatae, Oxytropido-Elynion or Arctostaphylo-Cetrarion. More ecological and floristical data are necessary.

Specimen examined: None. 


\section{Lepista irina var. montana Bon}

Previously published record: Vila \& al. (1998).

Collection cited: Site 7, 16 Aug 1997.

Notes on habitat: The habitat is described as 'between Dryas octopetala at 2220 m'. It may be Primulion intricatae, Oxytropido-Elynion or Arctostaphylo-Cetrarion. More ecological and floristical data are necessary.

Specimen examined: Not preserved, site 17, 10 Sep 2003, Arabidion caeruleae, leg. \& det. G. Corriol. - GC 05091415, site 17, 14 Sep 2005, Arabidion caeruleae, leg. G. Corriol \& N. Lavaupot, det. G. Corriol. - Not preserved, site 19, 14 Sep 2005, Arabidion caeruleae, leg. G. Corriol \& N. Lavaupot, det. G. Corriol.

\section{Lepista irinoides Bohus}

Previously published record: Bon \& Ballarà (1996).

Collection cited: Site 2, 17 Sep 1995.

Notes on habitat: The habitat is described as 'amond Dryas octopetala at 2150 m'. It may be Primulion intricatae, Oxytropido-Elynion or Arctostaphylo-Cetrarion. More ecological and floristical data are necessary.

Specimen examined: None.

Lepista martiorum (J. Favre) Bon

Previously published record: None.

Specimen examined: GC 05091414, site 17, 14 Sep 2005, in rather chionophilous Nardion strictae with Poa alpina, leg. G. Corriol \& N. Lavaupot, det. G. Corriol.

Lepista multiformis (Romell) Gulden

Previously published record: Bon \& Ballarà (1997).

Collection cited: Site 27, 15 Sep 1993.

Notes on habitat: The habitat is described as 'alpine grassland on slightly acidic soil, with few Salix herbacea and Loiseleuria procumbens'. It may be Salicion herbaceae.

Specimen examined: None.

Lichenomphalia pararustica (Clémençon) comb. ined. (= Omphalina pararustica Clémençon)

Previously published record: None.

Taxonomic notes: This taxon belongs to the Lichenomphalia velutina complex, but has not yet been recombined in this genus which regroups the lichenised omphalinoid basidiomycetes (Redhead $\&$ al. 2002). It differs from L. velutina ss. stricto mainly by its four spored basidia (Moreau 2005).

Notes on habitat: The habitat is described as 'on a slope, on mosses and naked soil, at $2200 \mathrm{~m}$ '. The altitude at which the collection was made leaves it open if the locality was alpine or subalpine. More ecological informations are needed. However, as lichenomphalias are well represented in arctic and alpine environments, we report this collection.

Specimen examined: NdM 97100205/2048-9, site 32, 2 Oct 1997, habitat not precisely known (see above), leg. N. de Munnik, det. G. Corriol.

Lichenomphalia velutina (Quél.) Redhead, Lutzoni \& Vilgalys

Previously published record: Ballarà (1997).

Collection cited: Site 35, 13 Jul 1996.

Notes on habitat: The habitat is described as 'Carici-Salicetum retusae, under Salix retusa at 
2300 m'. The Carici parviflorae-Salicetum retusae is the main Pyrenean association of basophilous snowbed from Arabidion caeruleae alliance, rich in dwarf willow. Specimen examined: None.

\section{Marasmius epidryas Kühner}

Previously published records: Bon \& Ballarà (1995), Vila \& al. (1997).

Collections cited: Site 2, 9 Oct 1994. - Site 7, 8 Aug 1996 and 16 Aug 1996.

Notes on habitat: The habitat is described as 'between Dryas octopetala at $2150 \mathrm{~m}$ ' and 'on rests of Dryas octopetala at 2220 m'. It may be Primulion intricatae, Oxytropido-Elynion or Arctostaphylo-Cetrarion. More ecological and floristical data are necessary.

Other unpublished data: Not preserved, site 30, 19 Sep 2003, on Dryas octopetala, in Oxytropido-Elynion, leg. \& det. N. de Munnik.

Specimen examined: Not preserved, site 16, 28 Aug 2003, on Dryas octopetala, in Oxytropido-Elynion, leg. \& det. G. Corriol. - GC 06081613, site 16, 16 Aug 2006, on Dryas octopetala, in Oxytropido-Elynion, leg. G. Corriol, C. Hannoire and E. Trouillard, det. G. Corriol.

Melanoleuca brevipes (Bull.) Pat.

Previously published record: None.

Specimen examined: Not preserved, site 21, 30 Aug 2002, Arabidion caeruleae, leg. \& det. G. Corriol.

\section{Melanoleuca catalaunica Singer}

Previously published record: Singer (1932).

Collection cited: Catalan Pyrenees close to Espot, at south-east of the Encantats, Spain.

Notes on habitat: The habitat is described as 'in alpine grassland' according to the original diagnosis. The only mention by Singer (loc. cit.) is given at $2150 \mathrm{~m}$, which is obviously a subalpine locality; in the key given by this author, he indicates " alpine region of Pyrenees (2000-2300 m) »; however, we think this is more likely a subalpine species.

Specimen examined: None.

Melanoleuca cognata var. robusta (J.E. Lange) Kühner

Previously published record: None.

Unpublished data: NdM 03091905/2249-5, site 30, 19 Sep 2003, Oxytropido-Elynion, leg. $\&$ det. N. de Munnik.

Specimen examined: None.

Melanoleuca decembris Métrod ex Bon (f. alpina M. Bon \& Ballarà prov.)

Previously published record: Bon \& Ballarà (1997).

Collection cited: Site 35, 4 Jul 1996.

Notes on habitat: The habitat is described as 'on limestone at 2300 m'. More floristical and ecological data are needed for habitat type identification.

Specimen examined: None.

Melanoleuca diverticulata Bon \& Moreno (f. alpina M. Bon \& Ballarà prov.)

Previously published record: Bon \& Ballarà (1996).

Collection cited: Site 35, 17 Sep 1995.

Notes on habitat: The habitat is described as 'among Salix retusa at 2300'. It is probably 
Arabidion caeruleae. Specimen examined: None.

Melanoleuca graminicola (Velen.) Kühner \& R. Maire

Previously published record: None.

Specimen examined: NdM 03091903/2249-5, site 30, 19 Sep 2003, Oxytropido-Elynion, leg. \& det. N. de Munnik, conf. G. Corriol.

\section{Melanoleuca metrodiana Bon}

Previously published record: Esteve-Raventós \& al. (1997).

Collection cited: Site 5, 14 Aug 1996.

Notes on habitat: The habitat is described as 'in alpine pasture land on basic soil, at $2250 \mathrm{~m}$ '.

It may be Primulion intricatae, but more ecological and floristical data are needed.

Specimen examined: None.

\section{Melanoleuca pseudoluscina Bon}

Previously published record: None.

Notes on distribution: This taxon seemed to be unknown from montainous areas up to now (Corriol 2005).

G. Corriol.

Specimen examined: GC 05091446, site 19, 14 Sep 2005, Arabidion caeruleae, leg. G. Corriol \& N. Lavaupot, det.

Melanoleuca rasilis (Fr.) Singer var. rasilis

Previously published record: Esteve-Raventós \& al. (1997).

Collection cited: Site 5, 14 Aug 1996.

Notes on habitat: The habitat is described as 'in alpine pasture land, at $2200 \mathrm{~m}$ '. More ecological and floristical data are needed to state the type of habitat.

Specimen examined: GC 05091402, site 17, 19 Sep 2005, Arabidion caeruleae, leg. G. Corriol \& N. Lavaupot, det. G. Corriol. - GC 06081602, site 16, 16 Aug 2006, Arabidion caeruleae, leg. G. Corriol, C. Hannoire and E. Trouillard, det.

G. Corriol.

Melanoleuca stridula (Fr.) Singer ss. Kühner

Previously published record: Vila \& al. (1998).

Collection cited: Site 7, 27 Aug 1997.

Notes on habitat: The habitat is described as 'between Dryas octopetala and Salix retusa at 2220 m'. It may be Arabidion caeruleae or Oxytropido-Elynion. More ecological and floristical details are needed.

Specimen examined: None.

Melanoleuca subalpina (Britzelm.) Bres. \& Stangl

Previously published record: Ballarà (1997).

Collection cited: Site 3, 25 Jul 1993 and 20 Jul 1996. - Site 35, 10 Jul 1996.

Notes on habitat: The habitat is described as 'in an alpine grassland, 2300-2350 m' and 'among grass, not far from Dryas octopetala, at 2300 m'. The last collection may be Primulion intricatae or Oxytropido-Elynion. More ecological and floristical data are necessary.

Specimen examined: None. 


\section{Melanoleuca tristis M.M Moser}

Previously published record: Vila \& al. (1998).

Collection cited: Site 7, 12 Aug 1997.

Notes on habitat: The habitat is described as 'between Loiseuleria procumbens and Dryas octopetala at $2220 \mathrm{~m}$ '. It may be Arctostaphylo-Cetrarion, but more ecological and flortistical informations are needed.

Specimen examined: None.

Mycena epipterygia var. candida (Weinm.) M. Bon \& P. Roux

Previously published record: Bon \& Ballarà (1997).

Collection cited: Above the Bouillouses lake, in the neighborhood of site 25, without date.

Notes on habitat: The habitat is described as 'in a mire with Carex div. species and Salix of repens type at $2500 \mathrm{~m}$ '. The ecological and floristical data are too fragmentary to determine accurately habitat type, though it likely belongs to the Scheuchzerio-Caricetea class.

Specimen examined: None.

\section{Mycena olivaceomarginata (Massee) Massee}

Previously published record: None.

Specimen examined: Not preserved, site 21, 30 Aug 2002, Arabidion caeruleae, leg. \& det. G. Corriol.

Mycena pura (Pers. : Fr.) P. Kumm.

Previously published record: Vila \& al. (1997).

Collection cited: Site 7, 16 Aug 1996.

Notes on habitat: The habitat is described as 'between Salix retusa and Dryas octopetala at 2300 m'. It may be Arabidion caeruleae or Oxytropido-Elynion. More ecological and floristical details are needed.

Specimen examined: Not preserved, site 21, 30 Aug 2002, Arabidion caeruleae, leg. \& det. G. Corriol. - GC 05091422, site 17, 14 Sep 2005, Arabidion caeruleae, leg. G. Corriol \& N. Lavaupot, det. G. Corriol.

Mycena pura f. alba (Gillet) Kühner

Previously published record: Vila \& al. (1998).

Collection cited: Site 7, 27 Aug 1997,

Notes on habitat: The habitat is described as 'between Dryas octopetala and Salix retusa at 2300 m'. It may be Arabidion caeruleae or Oxytropido-Elynion. More ecological and floristical details are needed.

Specimen examined: None.

Mycena pura f. purpurea (Gillet) Maas Geest.

Previously published record: None.

Specimen examined: Not preserved, site 17, 10 Sep 2003, Nardion strictae, leg. \& det. G. Corriol.

Myxomphalia maura (Fr. : Fr.) Hora

Previously published record: Ballarà (1997).

Collection cited: Site 2, 15 Sep 1996.

Notes on habitat: The habitat is described as 'among Funaria'. It is likely a burnt soil micro- 
habitat of the Funarion hygrometricae Hadec.

Specimen examined: None.

Panaeolus ater (J.E. Lange) Kühner \& Romagn. ex Bon

Previously published record: None.

Unpublished data: Not preserved, site 29, 3 Sep 2002, Nardion strictae, leg. \& det. N. de Munnik.

Specimen examined: None.

Panaeolus fimicola (Pers. : Fr.) Quél.

Previously published record: Ballarà \& Escànez (1999).

Collection cited: Site 35, 8 Jun 1996, 4 Jul 1996 and 21 Jun 1997.

Notes on habitat: The habitat is described as 'between Dryas octopetala at 2300 m'. It may be Primulion intricatae, Oxytropido-Elynion or Arctostaphylo-Cetrarion. More ecological and floristical data are necessary.

Previously published record: Vila \& al. (2001).

Collection cited: Site 12, 7 Aug 1999.

Notes on habitat: The habitat is described as "between Salix herbacea and Salix retusa at 2300 m'. It is probably Arabidion caeruleae. Corriol.

Specimen examined: GC 05091428, site 17, 14 Sep 2005, Nardion strictae, leg. G. Corriol \& N. Lavaupot, det. G.

Panaeolus foenisecii (Fr. : Fr.) Kühner

Previously published record: None.

Specimen examined: Not preserved, site 24, 25 Aug 2004, Arabidion caeruleae, leg. G. Corriol, T. Le Moal, P. Burr $\&$ N. Lavaupot, det. G. Corriol.

\section{Panaeolus rickenii Hora}

Previously published record: None.

Specimen examined: Not preserved, site 17, 10 Sep 2003, Nardion strictae, leg. \& det. G. Corriol. - GC 05091429, site 17, 14 Sep 2005, Nardion strictae, leg. G. Corriol \& N. Lavaupot, det. G. Corriol.

Panaeolus sphinctrinus (Fr.) Quél.

Previously published record: None.

Specimen examined: Not preserved, site 14, 22 Aug 2005, coprophilous, leg. G. Corriol, C. Bergès \& A.-M. Labouche, det G. Corriol.

Pholiotina coprophila var. exigua (Singer) Singer

Previously published record: None.

Specimen examined: GC 05082202, site 14, 22 Aug 2005, coprophilous, leg. G. Corriol, C. Bergès \& A.-M. Labouche, det G. Corriol.

Psilocybe chionophila Lamoure

Previously published record: Ballarà \& Escànez (1999).

Collection cited: Site 34, 25 Jun 1995.

Notes on habitat: The habitat is described as 'between mosses (Polytrichum sp.) and Salix 
herbacea at 2300 m'. It is probably Salicion herbaceae.

Specimen examined: None.

Psilocybe inquilina (Fr. : Fr.) Bres.

Previously published record: None.

Specimen examined: Not preserved, site 16, 28 Aug 2003, Arabidion caeruleae, leg. \& det. G. Corriol.

Psilocybe libertatis (Batsch: Fr.) F.H. Møller ss. Møller, P.D. Orton

Previously published record: None.

Taxonomic notes: This Psilocybe, well characterized by its dry pileipellis and small spores

(5-7 x 4-5 $\mu \mathrm{m})$ was first recognized in the alpine stage of the Alps by Bon \& Cheype (1995).

Specimen examined: GC 03082801, site 16, 28 Aug 2003, Arabidion caeruleae, in minute pioneer moss carpet, leg. $\&$ det. G. Corriol.

Rhodocybe caelata (Fr.) R. Maire

Previously published record: Ballarà (1997).

Collection cited: Site 35, 28 may 1994.

Notes on habitat: The habitat is described as 'in alpine pasture land at $2300 \mathrm{~m}$ '. It may be

Primulion intricatae, but floristical and ecological data are needed.

Specimen examined: None.

Rhodocybe nitellina (Fr.) Singer

Previously published record: Vila \& al. (1998).

Collection cited: Site 7, 27 Aug 1997.

Notes on habitat: The habitat is described as 'under Rhododendron ferrugineum between mosses, at $2300 \mathrm{~m}$ '. Acording to the altitude, it is possible that the alpine stage is reached. However, as Rhododendron ferrugineum is a typical subalpine plant, more ecological informations are needed. If alpine, the habitat may be Loiseleurio-Vaccinion where Rhododendron ferrugineus can be found in dwarf isolated forms.

Specimen examined: None.

Rickenella mellea (Singer \& Clémençon) Lamoure

Previously published record: Vila \& al. (1997).

Collection cited: Site 11, 12 Sep 1996.

Notes on habitat: The habitat is described as 'between mosses at $2150 \mathrm{~m}$ '. Unless it is likely a subalpine locality, this is the first Pyrenean mention of this orophile species. We quote it as we think it is likely to be found in the alpine stage too.

Specimen examined: GC 04092701, 27 Sep 2004, little lake under Oncet lake under the Pic du midi de Bigorre, alt. $2250 \mathrm{~m}$, Caricion fuscae, subalpine fen (our collection also comes from high subalpine stage), leg. \& det. G. Corriol.

Rugosomyces carneus (Bull. : Fr.) M. Bon

Previously published record: Rocabruna \& al. (1994).

Collection cited: Catalan Pyrenees, 4 Oct 1986.

Notes on habitat: The habitat is described as 'in a field at $2260 \mathrm{~m}$ '. One can't conclude on the habitat type. Ecological and floristical informations are necessary.

Previously published record: Ballarà \& Escànez (1999). 
Collection cited: Site 3, 24 Aug 1997.

Notes on habitat: The habitat is described as 'with Salix pyrenaica and S. retusa at 2250 m'. It may be Arabidion caeruleae according to the presence of $S$. retusa, but more information is needed.

Specimen examined: None.

Rugosomyces onychinus (Fr.) Raithelh.

Previously published record: Ballarà (1997).

Collections cited: Site 3, 4 Aug 1995 and 18 Aug 1996.

Notes on habitat: The habitat is described as 'among Dryas octopetala, 2300-2350 m'. It may be Primulion intricatae, Oxytropido-Elynion or Arctostaphylo-Cetrarion. More ecological and floristical data are necessary.

Specimen examined: None.

Russula alpigenes (Bon) Bon

Previously published record: None.

Specimen examined: GC 05083101, site 33, 31 Aug 2005, Salicion herbaceae, with Salix herbacea, leg G. Corriol, H. Chevallier, T. Guillonet \& N. Point, det. G. Corriol. - Not preserved, site 22, 9 Sep 2006, Salicion herbaceae, leg. \& det. G. Corriol. - GC 06083102, site 13, Montagne de Cap de Long, altitude 2575 m, 31 Aug 2006, Salicion herbaceae, leg. \& det. G. Corriol.

\section{Russula delica Fr.}

Previously published record: Vila \& al. (1997).

Collection cited: Site 7, 8 Aug 1996.

Notes on habitat: The habitat is described as 'between Dryas octopetala at $2220 \mathrm{~m}$ '. It may be Primulion intricatae, Oxytropido-Elynion or Arctostaphylo-Cetrarion. More ecological and floristical data are necessary.

Previously published record: Ballarà (1997).

Collection cited: Site 8, 25 Aug 1996.

Notes on habitat: The habitat is described as 'among Dryas octopetala and Vaccinium vitis-ideae, 2300-2400 m'. It may be Arctostaphylo-Cetrarion, but more ecological and floristical informations are necessary.

Specimen examined: None.

Russula nana Killerm.

Previously published record: Bon \& Ballarà (1996).

Collection cited: Site 3, 27 Jul 1995.

Notes on habitat: The habitat is described as 'among Dryas octopetala at 2200 m'. It may be Primulion intricatae, Oxytropido-Elynion or Arctostaphylo-Cetrarion. More ecological and floristical data are necessary.

Previously published record: Bon \& Ballarà (1997).

Collection cited: Site 34, 26 Aug 1995.

Notes on habitat: The habitat is described as 'with Salix herbacea at 2350 m'. It is probably Salicion herbaceae.

Other unpublished data: NdM 97100204/2048-9, site 32, 2 Oct 1997, Arabidion caeruleae with Salix reticulata and Dryas octopetala, leg. \& det. N. de Munnik.

Specimen examined: None. 
Russula nana var. alpina (A. Blytt \& Rostr.) Bon

Previously published record: Bon \& Ballarà (1996).

Collection cited: Site 3, 5 Aug 1995.

Notes on habitat: The habitat is described as 'among Dryas octopetala at 2350 m'. It may be Primulion intricatae, Oxytropido-Elynion or Arctostaphylo-Cetrarion. More ecological and floristical data are necessary.

Specimen examined: None.

\section{Russula norvegica Reid}

Previously published record: Bon \& Ballarà (1995).

Collection cited: Site 38, 10 Sep 1994.

Notes on habitat: The habitat is described as 'in the Salici-Anthelietum between Salix herbacea at 2350 m'. It is probably Salicion herbaceae.

Previously published record: Vila \& al. (1997).

Collection cited: Site 6, 2 Aug 1987.

Notes on habitat: The habitat is described as 'between Salix sp. at $2750 \mathrm{~m}$ '.It is probably Salicion herbaceae.

Previously published record: Vila \& al. (1997).

Collection cited: Site 7, 16 Aug 1996.

Notes on habitat: The habitat is described as 'between Salix retusa and Dryas octopetala at $2300 \mathrm{~m}$ ' and 'between Salix herbacea and Loiseleuria procumbens at $2400 \mathrm{~m}$ '. The first habitat may be Arabidion caeruleae or Oxytropido-Elynion. The second habitat may be Salicion herbaceae. More ecological and floristical details are needed.

Previously published record: Vila \& al. (1998).

Collection cited: Site 12, 14 Aug 1997.

Notes on habitat: The habitat is described as 'between Salix herbacea at $2350 \mathrm{~m}$ '. It is probably a snow-bed community from Salicetea herbaceae, but without more floristical or stational information, we cannot choose between the Salicion herbaceae or Arabidion caeruleae alliances.

Previously published record: Vila \& al. (1998).

Collection cited: Site 12, 14 Aug 1997.

Notes on habitat: The habitat is described as 'between Salix retusa and Salix herbacea at 2300 m'. It is probably Arabidion caeruleae.

Specimen examined: None.

\section{Russula oreina Singer}

Previously published records: Bon \& Ballarà (1996), Vila \& al. (1997).

Collections cited: Site 3, 4 Aug 1995. - Site 7, 8 Aug 1996.

Notes on habitat: The habitat is described as 'among Dryas octopetala at $2200 \mathrm{~m}$ ' and the same 'at 2220 m'. It may be Primulion intricatae, Oxytropido-Elynion or Arctostaphylo-Cetrarion. More ecological and floristical data are necessary.

Previously published record: Vila \& al. (1998).

Collection cited: Site 12, 14 Aug 1997.

Notes on habitat: The habitat is described as 'between Salix herbacea at 2450 m'. It is probably a snow-bed community from Salicetea herbaceae, but without more floristical or stational information, we cannot choose between the Salicion herbaceae or Arabidion caeruleae alliances.

Specimen examined: None. 


\section{Russula puellaris Fr.}

Previously published record: Bon \& Ballarà (1997).

Collection cited: Site 34, 26 Aug 1995.

Notes on habitat: The habitat is described as 'with Salix herbacea at 2350 m'. It is probably Salicion herbaceae.

Specimen examined: None.

\section{Russula sanguinea Fr.}

Previously published record: Vila \& al. (2001).

Collection cited: Site 7, 10 Aug 1999 and 24 Aug 1999.

Notes on habitat: The habitat is described as 'between Juniperus communis ssp. nana, Dryas octopetala and Salix retusa at 2300 m'. It may be Arabidion caeruleae or Oxytropido-Elynion. More ecological and floristical details are needed.

Specimen examined: None.

\section{Stropharia ochrocyanea Bon}

Previously published record: Bon \& Ballarà (1997).

Collection cited: Site 35, 31 Aug 1996.

Notes on habitat: The habitat is described as 'with Dryas octopetala and Loiseleuria procumbens at $2350 \mathrm{~m}$ '. It may be Arctostaphylo-Cetrarion, but more ecological and flortistical informations are needed.

Previously published record: Vila \& al. (2001).

Collection cited: Site 3, 22 Aug 1999.

Notes on habitat: The habitat is described as 'between Dryas octopetala and Salix retusa at 2240 m'. It may be Arabidion caeruleae or Oxytropido-Elynion. More ecological and floristical details are needed.

Previously published record: Vila \& al. (2001).

Collection cited: Site 4, 28 Sep 1999.

Notes on habitat: The habitat is described as 'between Salix reticulata and $S$. herbacea at 2210 m'. It is probably Arabidion caeruleae.

Specimen examined: GC 06081610, site 16, 16 Aug 2006, Arabidion caeruleae, leg. G. Corriol, C. Hannoire and E. Trouillard, det. G. Corriol.

\section{Stropharia pseudocyanea (Desm.: Fr.) Morgan}

Previously published record: Esteve-Raventós \& al. (1997).

Collection cited: Site 4, 14 Aug 1996.

Notes on habitat: The habitat is described as 'in alpine pasture land on basic soil at $2250 \mathrm{~m}$ '. It may be Primulion intricatae, but more ecological and floristical data are needed. Corriol.

Specimen examined: GC 05091434, site 17, 14 Sep 2005, Nardion strictae, leg. G. Corriol \& N. Lavaupot, det. G.

Stropharia semiglobata (Batsch : Fr.) Quél.

Previously published record: None.

Specimen examined: Not preserved, site 14, 22 Aug 2005, coprophilous, leg. G. Corriol, C. Bergès \& A.-M. Labouche, det G. Corriol. 
Tricholoma ramentaceum f. chamaesalicis Bon \& Ballarà

Previously published record: Bon \& Ballarà (1995).

Collection cited: Site 2, 9 Oct 1994.

Notes on habitat: The habitat is described as 'in the Carici-Salicetum retusae among Salix retusa and $S$. reticulata at $2050 \mathrm{~m}$ '. The altitude given by the authors is surprisingly low, but the plant association (Carici parviflorae-Salicetum retusae) is a typical Pyrenean basophilous snow-bed community rich in dwarf willow from Arabidion caeruleae.

Specimen examined: None.

\section{Tricholoma sulphureum var. rhodophyllum Métrod}

Previously published record: Bon \& Ballarà (1997).

Collection cited: Site 2, Jul 1996.

Notes on habitat: The habitat is described as 'with Salix retusa and S. pyrenaica at about 2300 $\mathrm{m}$ '. On the picture published by the authors, the only willow species we can see is Salix reticulata. It may be Arabidion caeruleae, but more ecological and floristical data are needed.

Specimen examined: None.

Gasteromycetideae

Bovista aestivalis (Bonord.) Demoulin

Previously published record: Vila \& al. (1998).

Collection cited: Site 7, 12 Aug 1997.

Notes on habitat: The habitat is described as 'between Dryas octopetala and Salix retusa at 2300 m'. It may be Arabidion caeruleae or Oxytropido-Elynion. More ecological and floristical details are needed.

Specimen examined: None.

Bovista dermoxantha (Vittad.) de Toni

Previously published record: None.

Specimen examined: GC 04091902, site 22, 19 Sep 2004, Salicion herbaceae, leg. G. Corriol, det. J. Mornand. - GC 05091420, site 19, 14 Sep 2005, Arabidion caeruleae, leg. G. Corriol \& N. Lavaupot, det. J. Mornand.

\section{Bovista glacialis Kreisel}

Previously published record: None.

Notes on distribution: This alpine Bovista was up to now only known from very few localities in the French Alps (Mornand 1990). Since we found it in different places in the central Pyrenees, it is probably a more frequent species here than in the Alps.

Specimen examined: GC 04082005, site 16, 20 Aug 2004, Arabidion caeruleae, leg. G. Corriol \& P. Burr, det. G. Corriol, conf. J. Mornand. - Not preserved, site 24, 25 Aug 2004, Arabidion caeruleae, leg. G. Corriol, T. Le Moal, P. Burr \& N. Lavaupot, det. G. Corriol. - GC 04091025, site 19, 10 Sep 2004, Arabidion caeruleae, leg. \& det. G. Corriol. - GC 05091401, site 17, 14 Sep 2005, Arabidion caeruleae, leg. G. Corriol \& N. Lavaupot, det. J. Mornand. GC 06081604, site 16, 16 Aug 2006, Arabidion caeruleae, leg. G. Corriol, C. Hannoire and E. Trouillard, det. G. Corriol.

Bovista limosa Rostr.

Previously published record: Magni (1989).

Collection cited: Site 13, near the Cap de Long lake, 28 Aug 1988. 
Notes on habitat: The habitat is not specified.

Specimen examined: None.

Bovista nigrescens Pers. : Pers.

Previously published record: Magni (1989).

Collection cited: Site 13, near the Cap de Long lake, 28 Aug 1998.

Notes on habitat: The habitat is described as 'pasture land'. We need more floristical and ecological data to interpret the type of habitat.

Other unpublished date: Not preserved, site 31, 15 Aug 2002, Primulion intricatae with Dryas octopetala and Salix pyrenaica, leg. \& det. N. de Munnik.

Specimen examined: Not preserved, site 19, 27 Aug 2004, Arabidion caeruleae, leg. G. Corriol, P. Burr \& P. Hériveau, det. P. Hériveau. - GC 04091005, site 19, 10 Sep 2004, Arabidion caeruleae, leg. \& det. G. Corriol. - Not preserved, site 17, 14 Sep 2005, Arabidion caeruleae, leg. G. Corriol \& N. Lavaupot, det. G. Corriol. - Not preserved, site 22, 9 Sep 2006, Salicion herbaceae, leg. \& det. G. Corriol.

Bovista plumbea Pers. : Pers.

Previously published record: Magni (1989).

Collection cited: Site 13, near the Cap de Long lake, 28 Aug 1988.

Notes on habitat: The habitat is not specified.

Other unpublished date: Not preserved, site 31, 15 Aug 2002, Primulion intricatae with Dryas octopetala and Salix pyrenaica, leg. \& det. N. de Munnik.

Specimen examined: None.

Bovista tomentosa (Vittad.) Quél..

Previously published record: None

Specimen examined: GC 06081603, site 16, 16 Aug 2006, Arabidion caeruleae, leg. G. Corriol, C. Hannoire and E. Trouillard, det. G. Corriol.

Lycoperdon marginatum Vitt. ex Moris \& de Not.

Previously published record: Vila \& al. (1998).

Collection cited: Site 7, 12 Aug 1997.

Notes on habitat: The habitat is described as 'between Dryas octopetala and Salix retusa at 2220 m'. It may be Arabidion caeruleae or Oxytropido-Elynion. More ecological and floristical details are needed.

Specimen examined: None.

Lycoperdon umbrinum Pers. : Pers.

Previously published record: Vila \& al. (1998).

Collection cited: Site 7, 8 Aug 1996.

Notes on habitat: The habitat is described as 'between Loiseleuria procumbens and Vaccinium uliginosum at $2400 \mathrm{~m}$ '. It is probably Loiseleurio-Vaccinion.

Specimen examined: None.

Tulostoma brumale Pers. : Pers.

Previously published record: None.

Specimen examined: Not preserved, site 20, 23 Aug 2003, Arabidion caeruleae, leg. \& det. G. Corriol. 
Vascellum pratense (Pers. : Pers.) Kreisel

Previously published record: None.

Unpublished data: Not preserved, Auzat (Ariège), 3 Sep 1995, leg J. Michel, det. N. de Munnik. - Not preserved, site 30, 19 Sep 2003, Oxytropido-Elynion, leg. \& det. N. de Munnik.

Notes on habitat: For the first collection, the habitat is described as 'acidic alpine grassland at 2660 m'. It may be Festucion supinae.

Specimen examined: None.

Aphyllophoromycetideae

Clavulina cinerea (Bull.) J. Schröt.

Previously published record: Ballarà (1997).

Collection cited: Site 34, 24 Aug 1996.

Notes on habitat: The habitat is described as 'among Salix herbacea'. It is probably Salicion herbaceae.

Specimen examined: Not preserved, site 17, 10 Sep 2003, Arabidion caeruleae, leg. \& det. G. Corriol.

Clavulina cristata (Holmsk.) J. Schröt.

Previously published record: None.

Specimen examined: Not preserved, site 21, 30 Aug 2002, Arabidion caeruleae, leg. \& det. G. Corriol.

Clavulina rugosa (Bull.) J. Schröt.

Previously published record: Vila \& al. (1998).

Collections cited: Site 12, 2 Aug 1997 and 14 Aug 1997.

Notes on habitat: The habitat is described as 'between Salix herbacea at 2350 m'. It is probably a snow-bed community from Salicetea herbaceae, but without more floristical or stational information, we cannot choose between the Salicion herbaceae or Arabidion caeruleae alliances.

Previously published record: Vila \& al. (1998).

Collection cited: Site 7, 27 Aug 1997.

Notes on habitat: The habitat is described as 'between Dryas octopetala and Salix retusa at 2220 m'. It may be Arabidion caeruleae or Oxytropido-Elynion. More ecological and floristical data are needed.

Specimen examined: None.

Polyporus melanopus (Pers.) Fr.

Previously published records: Ballarà (1997).

Collections cited: Site 8, 27 Jul 1995 and site 9, 5 Aug 1995.

Notes on habitat: The habitat is described as 'at a Salix pyrenaica base, 2300-2400 m' and 'at a Rhododendron ferrugineus base, 2250-2350 m'. The first collection may be from Primulion intricatae or Arabidion caeruleae. According to its altitude, the second collection may also be alpine. However the substrate is a typical subalpine plant. If alpine, the habitat may be Loiseleurio-Vaccinion in which Rhododendron ferrugineum can be found in dwarf isolated forms. For both collections, more ecological and floristical data are needed.

Specimen examined: None. 


\section{Ramaria roellinii Schild (f. catalaunica prov. Ballarà)}

Previously published record: Ballarà (1997).

Collection cited: Site 8, 25 Aug 1996.

Notes on habitat: The habitat is described as 'among mosses, Dryas octopetala and Salix retusa, 2300-2400 m'. It may be Arabidion caeruleae or Oxytropido-Elynion. More ecological and floristical details would be desirable.

Specimen examined: None.

Ramaria stricta (Pers. : Fr.) Quél.

Previously published record: Ballarà (1997).

Collection cited: Site 35, 31 Aug 1996.

Notes on habitat: The habitat is described as 'among Salix herbacea on calcareous soil, not far from Pinus uncinata at 2300 m'. A true alpine species (Salix herbacea) and a true subalpine species (Pinus uncinata) are quoted together. Each of them probably inhabit in different microstational positions. This case well illustrates the difficulty to say wether a collection is alpine or not without acute floristical and ecological description:

Specimen examined: None.

Thelephora caryophyllea (Schaeff. : Fr.) Fr.

Previously published record: Ballarà (1997).

Collection cited: Site 35, 13 Jul 1996.

Notes on habitat: The habitat is described as 'on ground, with mosses, Salix retusa and $S$. reticulata at 2300 m'. It may be Arabidion caeruleae.

Previously published record: Esteve-Raventós \& al. (1997).

Collection cited: Site 1, 31 Aug 1996.

Notes on habitat: The habitat is described as 'on humus, with Salix herbacea, on siliceous substrate at 2400 m'. It may be Salicion herbaceae.

Specimen examined: NdM 97100206/2048-9, site 32, 2 Oct 1997, Arabidion caeruleae, leg. N. de Munnik, det. G. Corriol. - Not preserved, site 21, 30 Aug 2002, Arabidion caeruleae, leg. \& det. G. Corriol. - GC 04091002, site 19, 10 Sep 2004, Arabidion caeruleae, leg. \& det. G. Corriol. - Not preserved, site 22, 19 Sep 2004, Salicion herbaceae, leg. \& det. G. Corriol. - Not preserved, site 16, 16 Aug 2006, Arabidion caeruleae, leg. G. Corriol, C. Hannoire and E. Trouillard, det. G. Corriol. - Not preserved, Troumouse circus (at the east of site 14), altitude 2300 m, 13 Aug 2006, Arabidion caeruleae, leg. $\&$ det. G. Corriol.

\section{ACKNOWLEDGEMENTS}

We are grateful to Jordi Vila (Barcelona, E), Luis Vilar (Institut Ecol., Jaca, E), Pierre-Arthur Moreau (Fac Sc. Pharm. \& Biol., Lille, F), Cécile Vignau (CBP, Bagnères-de-Bigorre, F) and Rolland Colléate† (La-Roche-sur-Yon, F), for their bibliographic help, Jordi Vila for his help in localizing spanish dans andorran sites, Catherine Brau-Nogué (CBP), Tangi le Moal (CBP), Delphine Cadars (CBP), Nadine Lavaupot (CBP), Peguy Burr (CBP), Carole Hannoire (CBP) and Elodie Trouillard (CBP) for their help in field investigations, Nicolas de Munnick (ARIANE, Foix, F) for providing us with unpublished Pyrenean alpine fungi data and material, Jean Mornand (Angers, F) and Denise Daly-Lamoure (Lyon, F) for their valuable help in the determination respectively of some Gasteromycetideae and some Cortinarius species and Torbjørn Borgen and David Boertmann for their instage about recent 
collections of Hygrocybe hygrocyboides. We are also grateful to Régis Courtecuisse (Fac Sc. Pharm. $\&$ Biol., Lille, F) for the critical revision of the manuscript and Rodger Hickman and Guy Corriol for linguistic improvement. Finally, we would like to thank our director Gérard Largier, for his understanding of the interest of macrofungi in the inventory and in the conservation problematics of a botanical conservatory structure.

This work was partially supported by a grant from the Conseil régional de Midi-Pyrénées and the European Union.

\section{REFERENCES}

Arnolds, E. 1981. Ecology and coenology of macrofungi in grasslands and moist heathlands in Drenthe, the Netherlands. Part 1. Introduction and synecology. - Biblthca mycol. 90: 1-407.

Ballarà, J. \& Escànez, Ll. 1999. Nou estudi de fongs alpí dels Pirineus catalans. - Revista Catalana micol. 20: 39-46.

Ballarà, J. 1997. Nou estudi d'espècies fúngiques interessants dels estatges alpí i subalpí dels Pirineus catalans. - Revista Catalana micol. 20: 1-24.

Bardat, J., Bioret, F., Botineau, M., Boullet, V., Delpech, R., Géhu, J.-M., Haury, J., Lacoste, A., Rameau, J.-C., Royer, J.-M., Roux, G. \& Touffet, J. 2004. Prodrome des végétations de France. - Muséum National d'Histoire naturelle, Paris.

Biziot, E. 1997. Alcune Inocybe più frequenti della zona alpina delle Dolomiti. $2^{\circ}$ contributo. - Rivista micol. 40: 339-362.

Bon, M. \& Ballarà, J. 1995. Aportació a l'estudi de la micoflora alpina dels Pireneus (1 a part). - Revista Catalana micol. 18: 39-50.

Bon, M. \& Ballarà, J. 1996. Aportació a l'estudi de la micoflora alpina dels Pireneus (2a part). - Revista Catalana micol. 19: 139-153.

Bon, M. \& Ballarà, J. 1997. Contribution à l'étude de la mycoflore alpine des Pyrénées (part 3). - Bull. Féd. mycol. Dauphiné-Savoie 146: 5-22.

Bon, M. \& Cheype, J.-L. 1987. Mycologie alpine au col du Joly. - Bull. Féd. mycol. Dauphiné-Savoie 106: 22-27.

Bon, M. \& Cheype, J.-L. 1997. Quelques espèces alpines intéressantes du col de Balme (2000-2250 m), Haute-Savoie. - Bull. Féd. mycol. Dauphiné-Savoie 138: 29-37.

Bon, M. 1985a. Stage Mycologie alpine. Lanslebourg (Savoie) du 1 au 3 septembre 1984. - Bull. Féd. mycol. Dauphiné-Savoie 96: 19-25.

Bon, M. 1985b. Quelques nouveaux taxons de la flore mycologique alpine. - Bull. Féd. mycol. Dauphiné-Savoie 97: 23-30.

Bon, M. 1989. Quelques Agaricomycètes intéressants de la zone alpine récoltés dans le Tessin. - Mycol. Helv. 3: 315-330.

Bon, M. 1991. Inventaire des espèces récoltées au stage de mycologie alpine (Les Arcs - 23-26 août 1990). - Bull. Féd. mycol. Dauphiné-Savoie 122: 25-28.

Bon, M. 1992. Clé monographique des espèces galéro-naucorioïdes. - Doc. mycol. 21: 1-89.

Bon, M. 1997. Clé monographique des inocybes alpnis. - Bull. Féd. mycol. Dauphiné-Savoie 144: 71-109.

Bon, M. 2002. Clé de détermination du genre Hebeloma (Fr.) P. Kumm. - Doc. mycol. 30: 3-39.

Braun-Blanquet, J. 1964. Pflanzensoziologie. Grundzüge der Vegetationskunde. Ed. 3, Springer Verlag, Wien. 
Bruchet, G. 1970. Contribution à l'étude du genre Hebeloma. - Bull. mens. Soc. Linn. Lyon Suppl. 6: $1-132$.

Candusso, M. 1997. Hygrophorus s. 1. Fungi Europaei vol. 6. - Libreria Basso, Alassio.

Cheype, J.-L. 1997. Quelques espèces intéressantes récoltées pendant l'été 1996 dans les Alpes au dessus de 2000 m. - Bull. Féd. mycol. Dauphiné-Savoie 144: 13-18.

Citérin, M. 1993. Essai d'une clé de détermination des hébélomes de la zone alpine. - Bull. Féd. mycol. Dauphiné-Savoie 128: 26-30.

Corriol, G. \& Largier, G. 2004 [2003]. Développement d'une activité sur les cryptogames non vasculaires au Conservatoire botanique national de Midi-Pyrénées. - Isatis 3: 9-16.

Corriol, G. 2005 [2004]. Deux Melanoleuca plus ou moins littoraux en position continentale. - Bull. Soc. mycol. France 120: 79-90.

Corriol, G. 2006 [2005]. — Sur l'intérêt mycologique de certaines phytocénoses pyrénéennes. (Actes du VII ${ }^{\text {ème }}$ colloque de botanique pyrénéeo-cantabrique, Bagnères-de-Bigorre, juillet 2004), Bull. Soc. hist. nat. Toulouse, 141: 83-89.

Corriol, G., de Munnik, N., Leblond, N., Lavaupot, N. \& Lay, S. 2004. État des lieux sur les bryophytes et les champignons en Midi-Pyrénées. Rapport final. - Conservatoire botanique national de Midi-Pyrénées (unpubl.).

Dupias, G. 1985. Végétation des Pyrénées. Notice détaillée de la partie pyrénéenne des feuilles 69 Bayonne - 70 Tarbes - 71 Toulouse - 72 Carcassonne - 76 Luz - 77 Foix - 78 Perpignan. Carte de la végétation de la France au $200000^{\text {ème }}$. Éditions du CNRS, Paris.

Esteve-Raventós, F. \& Vila, J. 1997. Algunos Inocybe de la zona alpina de los Pireneos de Catalunya. I. - Revista Catalana micol. 20: 177-186.

Esteve-Raventós, F. \& Vila, J. 1998. Algunos Inocybe de la zona alpina de los Pireneos de Catalunya. II. - Revista Catalana micol. 21: 185-201.

Esteve-Raventós, F., Gonzales, V. \& Arenal, F. 1997. Catálogo micológico de los macromicetos de areas alpinas y subalpinas del Parque Nacional de Ordesa y zonas limitrofes (Huesca, Espana) recogidos en 1996. - Bol. Soc. micol. Madrid 22: 155-186.

Eynard, M. 1977. Contribution à l'étude écologique des Agaricales des groupements à Salix herbacea. - PhD Thesis, Claude-Bernard University Lyon I, Lyon (unpubl.).

Eyssartier, G. \& Delannoy, A. 2006. Notes sur quelques espèces arctiques et alpines. Contribution à un inventaire mycologique du Svalbard. - Fungi non delineati 32: 1-87.

Favre, J. 1955. Les champignons supérieurs de la zone alpine du Parc National Suisse. - Lüdin, Liestal.

Ferrari, E. 2004. Inocybe rennyi (Berk. \& Br.) Sacc. et I. verbanense M. Bon \& Ferrari, ad. int. - Doc. mycol. 32: 39-46.

Galán, R., Raitviir, A. \& Vila, J. 1997. On some noteworthy alpine or subalpine Hyaloscyphaceae (Leotiales) found in the Pyrenees. - Revista Catalana micol. 20: 137-146.

Gulden G. \& Torkelsen, A.-E. 1996. Part 3. Fungi I. Basidiomycota: Agaricales, Gasteromycetales, Aphyllophorales, Exobasidiales, Dacrymycetales and Tremellales. - In: Elvebakk A. \& Prestrud P. (eds), A catalogue of Svalbard plants, fungi, algae and cyanobacteria. Norsk Polarinstitutt Skrifer 198: p. 173-206.

Gulden, G. \& Jenssen, K.M. 1982. Mycena and related genera in alpine habitats of South Norway. - In Laursen, G.A. Ammirati, J.F. : Arctic and Alpine Mycology. Univ. Washington Press: p. 164-197.

Gulden, G. \& Vesterholt, J. 1999. The genera Galerina and Phaeogalera (Basidiomycetes, Agaricales) on the Faroe Islands. - Nord. J. Bot. 19: 685-706.

Gulden, G. 1980. Alpine Galerinas (Basidiomycetes, Agaricales) with special reference to their occurrence in South Norway at Finse on Hardangervidda. - Norw. J. Bot. 27: 219-253. 
Gulden, G. 1992. Galerina Earle. - In: Hansen, L. \& Knudsen, H. (eds), Nordic Macromycetes. Volume 2. Polyporales, Boletales, Agaricales, Russulales. - Nordsvamp, Copenhagen, pp. 306-314.

Gulden, G. 2005. A preliminary guide to the macromycetes in the Finse area, Hardangervidda, Norway. - (unpubl. draft presented at ISAM VII, Oslo).

Häffner, J. 1987. The genus Helvella, morphology and taxonomy. - Z. mycol. 7: Suppl: 1-165.

Horak, E. 1987a. Astrosporina in the alpine zone of the Swiss National Park (SNP) and adjacent regions. - Arct. alp. Mycol. 2: 205-234.

Horak, E. 1987b. Revision des von J. Favre (1955) aus der Region Nationalparkes bescrieben alpinen Arten von Cortinarius subgen. Telamonia (Agaricales). - Candollea 42: 771-803.

Horak, E. 1993. Entoloma in the alpine zone of the Alps: 1. Revision of the taxa described by J. Favre (1955). 2. New records from the Swiss National Park and other localitions in the Alps. - Arct. alp. Mycol. 3: 63-91.

Jamoni, P.G. 1993. I Cortinari della sezione Hinnulei nella zona alpina superior. - Doc. mycol. 23: 19-23.

Jamoni, P.G. 1995a. Russulaceae della zona alpina. Proposta di chiavi di determinazione per le specie crescenti nella zona alpina delle Alpi. - Rivista micol. 38: Suppl. 2: 75-80.

Jamoni, P.G. 1995b. I funghi dell'Ambiente Alpino 10a Parte. - Funghi Ambiante 68: 5-31.

Kühner, R. \& Lamoure, D. 1970. Agaricales de la zone alpine. Introduction. - Bull. Soc. mycol. France 86: 875-880.

Kühner, R. \& Lamoure, D. 1986. Catalogue des Agaricales (Basidiomycètes) de la zone alpine du Parc national de la Vanoise et des régions limitrophes. - Trav. sci. Parc natl Vanoise 15: 103-187.

Kühner, R. 1977. Agaricales de la zone alpine. Hygrophoracées. - Bull. Soc. mycol. France 93: 121-144.

Laberche, J.C. 1989. Mapa pedològic de les valls d'Andorra 1: 50 000. - Institut d'Estudis Andorrans, Centre de Perpinyà, Perpinyà.

Lamoure, D. 1975. Agaricales de la zone alpine. Genre Omphalina (2 ${ }^{\mathrm{ème}}$ partie). - Trav. sci. Parc natl Vanoise 6: 153-166.

Lamoure, D. 1982. Agaricales de la zone alpine du Parc national des Écrins. Première contribution: Haute vallée de la Romanche. - Trav. sci. Parc natl Écrins 2: 119-123.

Lassueur, R. 1989. Première contribution à la flore des Discomycètes du sud-ouest de la France. - Bull. coord. mycol. midi toulousain pyrénéen 4: 39-54.

Magni, J.-F. 1989. Présentation des espèces du genre Bovista trouvées en zone alpine des Pyrénées. - Bull. coord. mycol. midi toulousain pyrénéen 5: 41-44.

Meusers, M. 1996. Bestimmunsschlüssel für europäische Arten der Gattungen Conocybe und Pholiotina. - Österr. Z. Pilzk. 5: 247-272.

Moreau, P.-A. 2005. Les basidiolichens : des champignons (presque) comme les autres. - Bull. mycol. bot. Dauphiné-Savoie 178: 75-80.

Mornand, J. 1990. Les Gastéromycètes de France (6 - Lycoperdales). - Doc. mycol. 20: 1-24.

Noordeloos, M.E. \& Gulden, G. 2004. The genus Entoloma (Basidiomycetes, Agaricales) on Svalbard. - Memoirs of the New York Botanical Garden 89: 97-106.

Noordeloos, M.E. 2004. Entoloma s.1. - Fungi eur. 5A: 1-1378.

Redhead, S.A., Lutzoni, F., Moncalvo, J.-M. \& Vilgalys, R. 2002. Phyllogeny of agarics: partial systematics solutions for core omphalinoid genera in the Agaricales (Euagarics). - Mycotaxon 83: 19-57.

Rocabruna, A, Tabarés, M., Ballarà, J. \& Vila, J. 1994. Primera aportació al coneixement de la Micoflora dels Pireneos y Prepireneos de Catalunya. - Bull. Soc. Catalana micol. 16-17: 47-86.

Schumacher, T. \& Jenssen, K.M. 1992. Discomycetes from the Dovre mountains, Central South Norway. - Arct. alp. Fungi 4: 1-66. 
Schumacher, T.1990. The genus Scutellinia (Pyronemataceae). - Opera Botanica 101: 1-107.

Senn-Irlet, B. 1986. Ökologie, Soziologie und Taxonomie alpiner Makromyzeten (Agaricales, Basidiomycetes) der Scweizer Zentralalpen. - PhD Thesis, Berne University, Berne (unpubl.).

Senn-Irlet, B. 1988. Macromycetes in alpine snow-bed communities - mycocoenological investigations. - Acta bot. neerl. 37: 251-263.

Senn-Irlet, B. 1993. The mycoflora of Alpine mire communities rich in Salix. - Arct. alp. Mycol. 3: 235-249.

Singer, R. 1932. Etude systématique sur les Melanoleuca d'Europe et clé des espèces observées en Catalogne. - Cavanillesia 7: 122-132.

Vila, J. \& Esteve-Raventós, F. 1998. Dermoloma pseudocuneifolium, Entoloma lanicum y E. scabropellis (Basidiomycetes) en el piso alpino del valle de Núria (Pireneos, Cataluña). - Bol. Soc. micol. Madrid 23: 151-158.

Vila, J. \& Llimona, X. 1998. Els fongs del Parc National d'Aigüestortes i Estany de Sant Maurici i àrees pròximes, segons dades recents (1991-1997). - In: Anonymous, La investigació al Parc Nacional d'Aigüestortes i Estany de Sant Maurici. Quartes Jornades sobre recerca al Parc Nacional d'Aigüestortes i Estany de Sant Maurici, 22-24 d'Octubre de 1997, Espot (Pallars Sobirà), Dalmau, Lleida: 137-151.

Vila, J., Esteve-Raventós, F., Llistosella, J. \& Llimona, X. 2001. Contribución al conocimiento del los hongos del piso alpino de los Pireneos de Cataluña. III. - Revista Catalana Micol. 23: 51-65.

Vila, J., Llistosella, J. \& Llimona, X. 1997. Contribució al coneixement dels fongs de l'estatge alpí dels Pireneus de Catalunya. I. - Revista Catalana Micol. 20: 221-232.

Vila, J., Llistosella, J. \& Llimona, X. 1998. Contribució al coneixement dels fongs de l'estatge alpí dels Pireneus de Catalunya. II. - Revista Catalana Micol. 21: 93-113.

Watling R. 1982. British Fungus Flora: Agarics and Boleti. Vol. 3: Bolbitiaceae: Agrocybe, Bolbitius, Conocybe. - Royal Botanic Garden, Edinburgh. 